\title{
SERIES
}

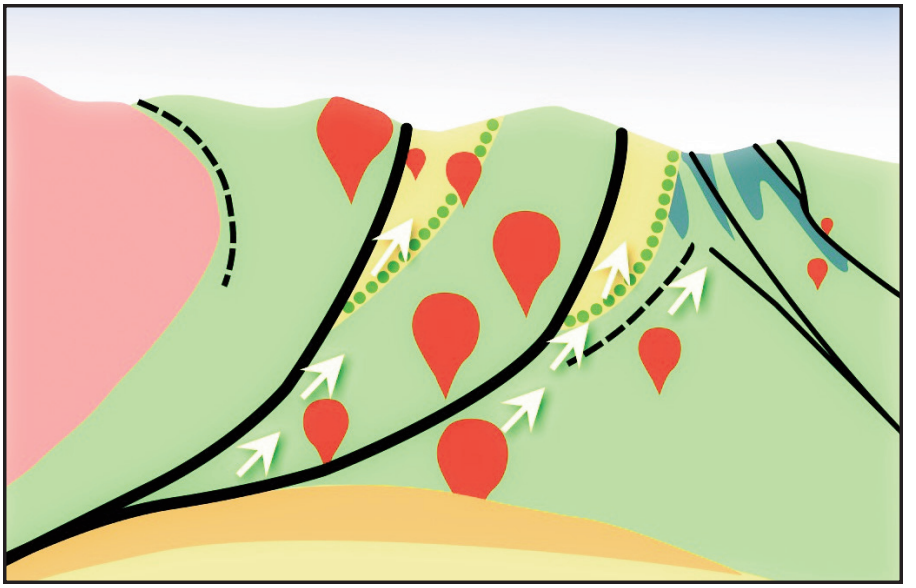

Igneous Rock Associations 19. Greenstone Belts and Granite-Greenstone Terranes: Constraints on the Nature of the Archean World

\section{P.C. Thurston}

Department of Earth Sciences

Laurentian University

935 Ramsay Lake Road, Sudbury

Ontario, P3E 2C6, Canada

E-mail: pthurston@Laurentian.ca

\section{SUMMARY}

Greenstone belts are long, curvilinear accumulations of mainly volcanic rocks within Archean granite-greenstone terranes, and are subdivided into two geochemical types: komatiitetholeiite sequences and bimodal sequences. In rare instances where basement is preserved, the basement is unconformably overlain by platform to rift sequences consisting of quartzite, carbonate, komatiite and/or tholeiite. The komatiite-tholeiite sequences consist of $\mathrm{km}$-scale thicknesses of tholeiites, minor intercalated komatiites, and smaller volumes of felsic volcanic rocks. The bimodal sequences consist of basal tholeiitic flows succeeded upward by lesser volumes of felsic volcanic rocks. The two geochemical types are unconformably overlain by successor basin sequences containing alluvial-fluvial clastic metasedimentary rocks and associated calc-alkaline to alkaline volcanic rocks.

Stratigraphically-controlled geochemical sampling in the bimodal sequences has shown the presence of Fe-enrichment cycles in the tholeiites, as well as monotonous thicknesses of tholeiitic flows having nearly constant $\mathrm{MgO}$, which is explained by fractionation and replenishment of the magma chamber with fresh mantle-derived material. Geochemical studies reveal the presence of boninites associated with the komatiites, in part a result of alteration or contamination of the komatiites. Within the bimodal sequences there are rare occurrences of adakites, $\mathrm{Nb}$-enriched basalts and magnesian andesites.

The greenstone belts are engulfed by granitoid batholiths ranging from soda-rich tonalite-trondhjemite-granodiorite to later, more potassic granitoid rocks. Archean greenstone belts exhibit a unique structural style not found in younger orogens, consisting of alternating granitoid-cored domes and volcanicdominated keels. The synclinal keels are cut by major transcurrent shear zones.

Metamorphic patterns indicate that low-pressure metamorphism of the greenstones is centred on the granitoid batholiths, suggesting a central role for the granitoid rocks in metamorphosing the greenstones. Metamorphic patterns also show that the proportion of greenstones in granite-greenstone terranes diminishes with deeper levels of exposure.

Evidence is presented on both sides of the intense controversy as to whether greenstone belts are the product of modern plate tectonic processes complete with subduction, or else the product of other, lateral tectonic processes driven by the 'mantle wind.' Given that numerous indicators of plate tectonic processes - structural style, rock types, and geochemical features - are unique to the Archean, it is concluded that the evidence is marginally in favour of non-actualistic tectonic processes in Archean granite-greenstone terranes.

\section{RÉSUMÉ}

Les ceintures de roches vertes sont des accumulations longiformes et curvilinéaires, principalement composées de roches volcaniques au sein de terranes granitique archéennes, et étant subdivisées en deux types géochimiques: des séquences à komatiite-tholéite et des séquences bimodales. En de rares occasions, lorsque le socle est préservé, ce dernier est recouvert en discordance par des séquences de plateforme ou de rift, constituées de quartzite, carbonate, komatiite et/ou de tholéiite. Les séquences de komatiite-tholéiite forment des épais- 
seurs kilométriques de tholéiite, des horizons mineurs de komatiites, et des volumes de moindre importance de roches volcaniques felsiques. Les séquences bimodales sont constituées à la base, de coulées tholéiitiques surmontées par des volumes mineurs de roches volcaniques felsiques. Ces deux types géochimiques sont recouverts en discordance par des séquences de bassins en succession contenant des roches métasédimentaires clastiques fluvio-alluvionnaires associées à des roches volcaniques calco-alcalines à alcalines.

Un échantillonnage à contrôle stratigraphique des séquences bimodales a révélé la présence de cycles d'enrichissement en $\mathrm{Fe}$ dans les tholéiites, ainsi que des épaisseurs continues d'épanchements tholéiitiques ayant des valeurs presque constante en $\mathrm{MgO}$, qui s'explique par la cristallisation fractionnée et le réapprovisionnement de la chambre magmatique par du matériel mantélique. Les études géochimiques montrent la présence de boninites associées aux komatiites, résultant en partie de l'altération ou de la contamination des komatiites. Au sein des séquences bimodales, on retrouve en de rares occasions des adakites, des basaltes enrichis en $\mathrm{Nb}$ et des andésites magnésiennes.

Les ceintures de roches vertes sont englouties dans des batholites granitoïdes de composition passant des tonalites-trondhjémites-granodiorites enrichies en sodium, à des roches granitoïdes tardives plus potassiques. Les ceintures de roches vertes archéennes montrent un style structural unique que l'on ne retrouve pas dans des orogènes plus jeunes, et qui est constitué d'alternances de dômes à cœur granitoïdes et d`affaissements principalement composés de roches volcaniques. Les synclinaux formant les affaissements sont recoupés par de grandes zones de cisaillement.

Les profils métamorphiques indiquent que le métamorphisme de basse pression des roches vertes est centré sur les batholites, indiquant un rôle central des roches granitö̈des durant le métamorphisme des roches vertes. Les profils métamorphiques montrent également que la proportion de roches vertes dans les terranes granitiques diminue avec l'exposition des niveaux plus profonds.

On présente les arguments des deux côtés de l'intense controverse voulant que les ceintures de roches vertes soient le produit de processus moderne de la tectonique des plaques incluant la subduction, ou alors le produit d'autres processus tectoniques découlant du « flux mantélique ». Étant donné la présence des indicateurs des processus de tectonique des plaques - style structural, les types de roches, et les caractéristiques géochimiques - ne se retrouvent qu'à l'Archéen, nous concluons que les indices favorisent légèrement l'option de processus tectoniques non-actuels dans les terranes granitiques de roches vertes à l'Archéen.

Traduit par le Traducteur

\section{INTRODUCTION}

Greenstone belts are long, linear accumulations of predominantly volcanic rocks that typically feature relatively low metamorphic grade. The belts range from the $\sim 3825 \mathrm{Ma}$ volcanic rocks of the Porpoise Cove belt of northeastern Québec (O’Neil et al. 2008) and the $3710 \mathrm{Ma}$ Isua greenstones of western Greenland (Baadsgaard et al. 1984), to Paleoproterozoic greenstones such as the Trans-Hudson orogen (Canada) and the Ashanti gold belt of west Africa. Archean greenstone belts are an important component of granite-greenstone subprovinces that form the major part of Archean cratons (Fig. 1; Percival and Stott 2010). Granite-greenstone subprovinces consist of the greenstone belts themselves and related granitoid rocks, which include granitoid basement and synvolcanic, syn-tectonic and post-tectonic plutons. Greenstone belts are sensitive recorders of their environment of formation, such as atmospheric composition (Farquhar and Wing 2003), oceanic chemistry and depth (Bolhar et al. 2005; Kamber 2010; Thurston et al. 2012) and mantle dynamics, such as the presence or absence of subduction (Wyman et al. 2002; Bédard et al. 2013). Greenstone belts are economically important as a repository for syngenetic mineralization, e.g. volcanogenic massive sulphides (VMS) deposits (Galley et al. 2007a), uranium, komatiite-associated nickel deposits (Lesher and Keays 2002), and epigenetic deposits, such as lode gold. The petrogenetically associated granitoid rocks are sources of rare metal mineralization in pegmatites and accessory phases. The orogenic lode gold deposits of Canada are almost exclusively in the volcanic rocks and successor basin units of Archean greenstone belts (Goldfarb et al. 2005), whereas their occurrence in granitoid plutons of the greenstone belts is minor (Robert et al. 1997).

The objectives of this paper are to describe all the major aspects of granite-greenstone terranes: rock types, volcanology, sedimentology, igneous petrology, structural geology, and metamorphism, and to assess the merits of tectonic models required to produce these terranes. This review will concentrate upon the Superior Province but will provide examples from other shields, principally to illustrate that the features and processes described are not unique to the Superior Province.

It is important to recognize that there are two points of view concerning the origin of greenstones: a) an actualistic point of view involving the operation of plate tectonics in the Archean, and b) various non-plate tectonic scenarios invoked only for Archean and some Proterozoic greenstones. There is at this time an intense debate as to which of these scenarios is correct (Stern 2005; Percival 2007; Percival and Stott 2010; Wyman et al. 2011; Hamilton 2011; Bédard et al. 2013). In this paper, a balance is sought between the largely geochemical arguments presented for Archean subduction (Hollings 1999, 2002; Kerrich et al. 1999; Polat and Kerrich 2001, 2002; Wyman et al. 2002) vs. the geodynamic and geochemical arguments opposing Archean subduction (Hamilton 2011; Bédard et al. 2013; Kamber 2015).This paper also seeks to highlight the importance of integration of geochemical arguments with stratigraphy and structure.

\section{CRATON SUBDIVISIONS}

The Superior Province is subdivided into Paleo- to Mesoarchean continental fragments, Neoarchean juvenile oceanic fragments, and orogenic flysch terranes (Percival and Stott 2010). The individual terranes are mainly fault-bounded. A less controversial subdivision of Archean cratons used herein recognizes 'granite-greenstone' terranes or subprovinces and 'orogenic flysch' terranes (Fig. 1). Orogenic flysch units are relatively rare; the other major non-Superior Province occurrence is the Limpopo orogen linking the Kaapvaal and Zimbabwe cratons (Eglington and Armstrong 2004; Schmitz et al. 2004). Review of other Archean cratons shows that they 


\section{PHANEROZOIC \\ $\mathrm{Ph}$ Platform sediments PROTEROZOIC \\ Kw Keweenawan \\ Th Trans-Hudson orogen \\ ARCHEAN \\ VII Douglas Harbour domain \\ VI Utsalik domain \\ V Goudalie domain \\ IV L. Minto domain \\ II Tikkerutuk domain \\ Inukjuak domain \\ BS Bienville subprovince \\ LG La Grande subprovince \\ OnS Opinaca subprovince}

AC Ashuanipi complex

Ocs Opatica subprovince

PT Pontiac terrane

WAT Wawa-Abitibi terrane

KU Kapuskasing uplift

QT Quetico terrane

EWT E. Wabigoon terrane

WVTT W. Wabigoon terrane

WRT Winnipeg R. Terrane

ERT English R. terrane

NCS North Caribou superterrane

OSD Oxford-Stull domain

NSS Northern Superior superterrane

MT Marmion terrane

BR Bird R. subprovince

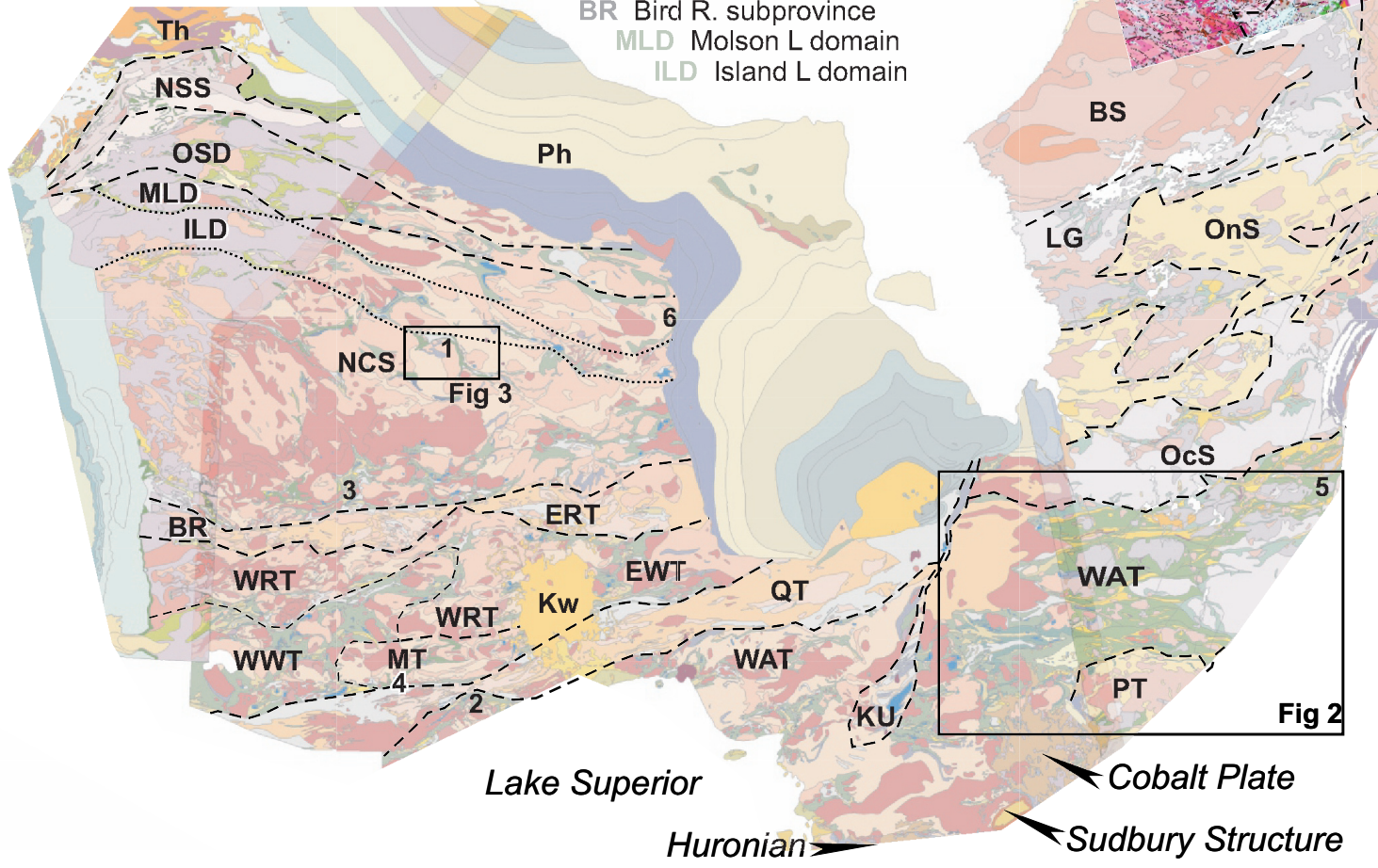

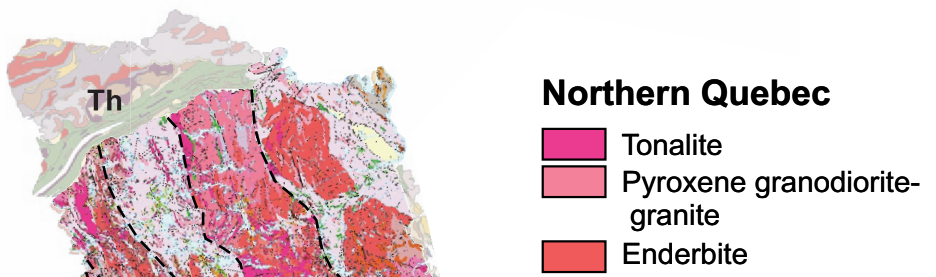

Superior Province

Greenstones

Metasediments

Gneissic tonalites

Foliated tonalites

Late granites

High grade

metasediments

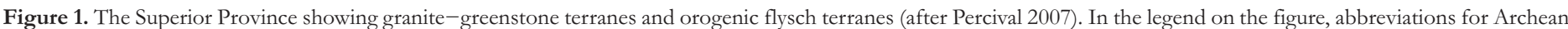

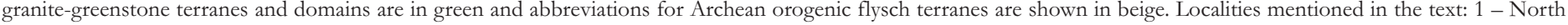

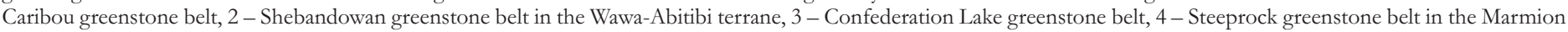
terrane, 5 - Chibougamau area within the Abitibi greenstone belt, 6 - Ring of Fire area shown on Figure 26. Figure is after Percival (2007).

are dominated by granite-greenstone terranes; the greenstones are mostly at greenschist grade, but smaller areas achieve amphibolite-granulite grade.

\section{BASEMENT - A RARE RELATIONSHIP}

A small number of Archean greenstone belts lie unconformably upon basement in the Superior Province (Wilks and Nisbet 1988; Breaks et al. 2001) and in the Zimbabwe craton (Martin et al. 1993; Bickle et al. 1994). In places, the greenstone-granitoid contact is a regolith, reflecting subaerial exposure, for example at the base of the Keeyask assemblage in the North Caribou belt of the Superior Province (Fig. 2) and at the base of Zimbabwe greenstones (Thurston et al. 1991; Martin et al. 1993). However, at Steeprock in the Superior Province (Wilks and Nisbet 1988) the unconformity is a submarine contact consisting of quartzose clastic units overlying the granitoid substrate. These basal unconformities and inter-assem- blage unconformities clearly indicate that some greenstones formed in place. Additional evidence for autochthonous origin of some greenstones is discussed in a subsequent section.

\section{LITHOTECTONIC ASSEMBLAGES}

Since the 1920s, geologists have been able to decipher the stratigraphy of greenstone belts with way-up indicators such as pillows and graded bedding in sedimentary and volcaniclastic units. With the knowledge of stratigraphic polarity, greenstones are observed to occupy synclinoria or keels that are interspersed with domes cored by granitoid batholiths (Fig. 3). Historically, greenstone belts were divided into Keewatin and Timiskaming units (Gunning and Ambrose 1939). Keewatin units are pre-deformation, largely volcanic units containing minor intercalated metasedimentary rocks, whereas Timiskaming units refer to unconformably overlying successor basins comprising post-early deformation, alluvial-fluvial to deep- 
basin metasedimentary rocks that contain lesser fine clastic units and calc-alkaline to alkaline volcanic rocks.

The concept of lithotectonic assemblages developed for the Cordilleran orogen (Tipper et al. 1981) was applied to greenstone belts to distinguish units of differing age or geodynamic setting (Thurston 1991; Thurston and Ayres 2004). Within Archean greenstone belts, the following assemblage types are recognized: 1) shallow-water, quartz- and carbonate-rich platforms with minor volcanic rocks, unconformably overlying granitoid or volcanic basement; 2) shallow- to deepwater komatiites and tholeiitic basalts overlying platformal sequences or granitoid basement; 3) deep-water komatiite-tholeiite or tholeiite sequences; 4) bimodal deepwater sequences dominated by tholeiitic basalt and containing minor felsic volcaniclastic rocks, chert, and iron-formation; 5) shallow-water to emergent bimodal successions; and 6) subaerial sedimentary rocks intercalated with subordinate alkaline to calc-alkaline volcanic rocks (Thurston and Chivers 1990). Greenstone belts commonly contain multiple assemblages (Fig. 2). At the craton scale, a stratigraphic/temporal progression from assemblage types 1 to 6 is observed (Thurston and Chivers 1990; Thurston and Ayres 2004).

\section{Quartzite-Carbonate Platforms}

Quartzite-carbonate platforms are relatively rare but have been described in the Superior, Churchill, and Slave Provinces of Laurentia (Donaldson and de Kemp 1998; Bleeker 2002), as well as in the Yilgarn (Gee et al. 1981), Pilbara (Van Kranendonk et al. 2007b) and Baltic (Thurston and Kozhevnikov 2000) cratons (Fig. 4A, B). These sequences contain shallow-water structures such as hummocky and herringbone cross-stratification and mudstone drapes, and progress upward through stromatolite-bearing carbonates (Arias et al. 1986; Wilks and Nisbet 1988; Bleeker 2002) and shales to deeper water komatiite-tholeiite sequences (described below). These shallowwater sedimentary units are overlain by shale and banded ironformation (BIF) that are finely laminated and, based on the lack of structures other than loading structures, represent deposition below storm wave base. Quartzite-bearing sequences in the Slave craton are related to craton rifting (Mueller and Pickett 2005), a model which also fits the Superior Province (Thurston 2003).

Shallow- to Deep-Water Komatiite- Tholeiite Sequences The platformal sequences are overlain by relatively thin (metres to hundreds of metres), areally restricted sequences of komatiitic and tholeiitic flows. Primary structures range from spinifex-textured komatiitic flows to pillowed mafic flows, all representative of uncertain water depth. These sequences are in tectonic or stratigraphic contact with overlying kilometrescale thicknesses of intercalated komatiite and tholeiite flows (Thurston et al. 1991).

\section{Deep-Water Komatiite-Tholeiite Sequences}

Individual tholeiitic basalt flows displaying distinctive textures (e.g. glomeroporphyritic or variolitic) are traceable for tens of $\mathrm{km}$ and grade from thick, proximal, massive gabbroic-textured flows, to master tubes with branching megapillows that grade distally into normal-sized pillows with a cross-sectional area averaging $2600 \mathrm{~cm}^{2}$ (Sanschagrin 1982). Glomeroporphyritic basalts are commonly high in the stratigraphy and serve as marker horizons (Phinney et al. 1988; Blackburn et al. 1991). 

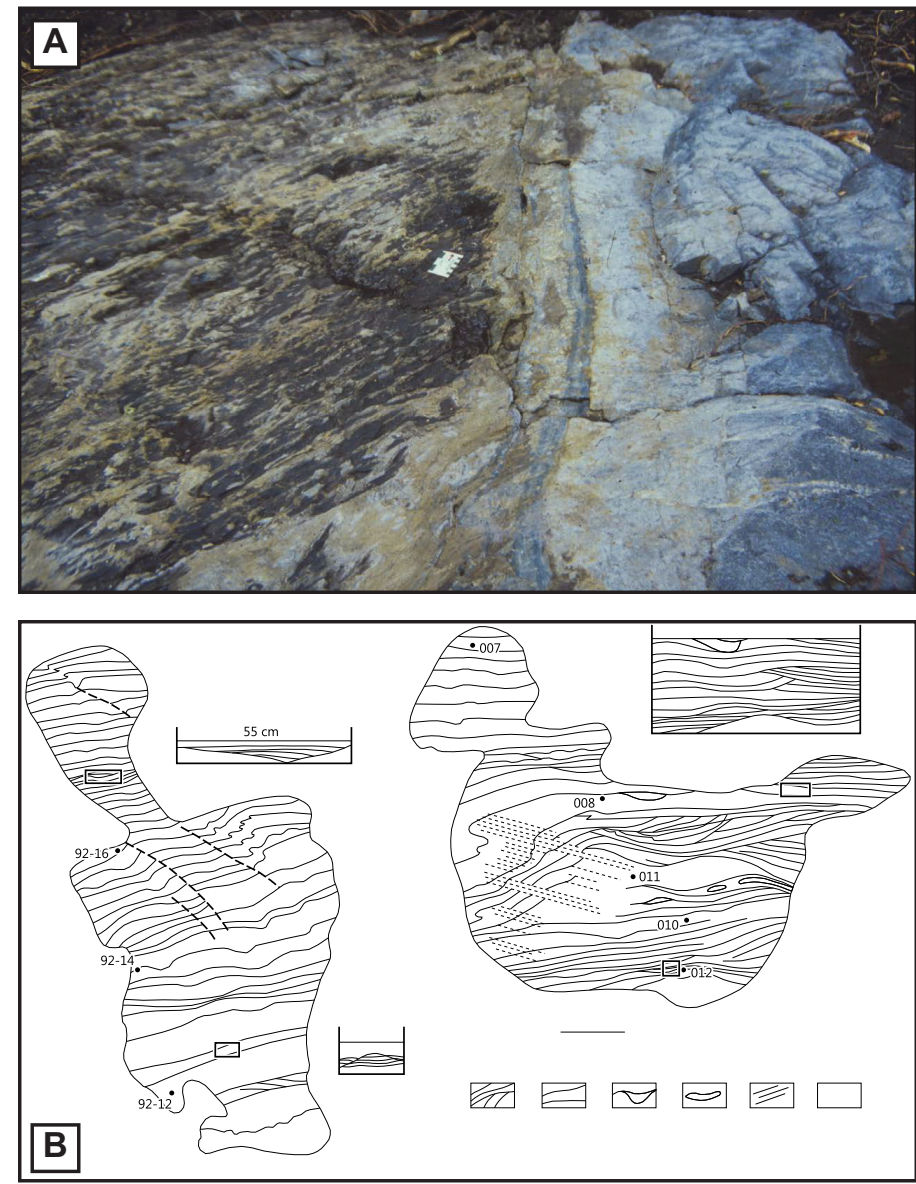

Figure 4. Basal unconformity in a greenstone belt and primary structures in basal quartz arenites. A. Unconformity at the base of the Keeyask metasedimentary assemblage in the North Caribou greenstone belt, North Caribou terrane, Superior Province. (Photo by F. Breaks). To the left is a weathered basalt flow with increasing intensity of alteration to the right, approaching the contact with the quartz arenite. B. Hummocky cross-stratification in quartz arenites of the Hisovaara greenstone belt in the Baltic Shield (Thurston and Kozhevnikov 2000).

The komatiites constitute a maximum of $5 \%$ of the stratigraphy in the Abitibi ${ }^{1}$ greenstone belt (Sproule et al. 2002) and their position in the stratigraphic column is not consistent, occurring as basal units such as the Tisdale assemblage, or higher in the stratigraphy such as the Kidd-Munro assemblage (Houlé et al. 2008b).

Komatiitic magmas differ from basalts in being hotter $\left(\sim 1600^{\circ}\right.$ vs. $\left.\sim 1200^{\circ} \mathrm{C}\right)$ and less viscous. These two parameters profoundly affect the physical volcanology of these magmas. In the classic exposures in the Pyke Hill area (Pyke et al. 1973) of the Abitibi greenstone belt, flows have rubbly flow tops, followed downward by spinifex-textured olivine, a cumulate olivine zone and a chilled base. Komatiitic magmas display: 1) a flood-flow facies of substantial extent consisting of intrusive and extrusive units; 2) a laterally extensive compound-flow facies with linear troughs up to $150 \mathrm{~m}$ thick flanked by metrescale flows; and 3) a ponded-flow facies. Initial flows have a low aspect ratio and propagate laterally beneath a solidified crust (Hill 2001). As the upper crust thickens, it begins to slow the advance of the flow and additional magma is accommo-

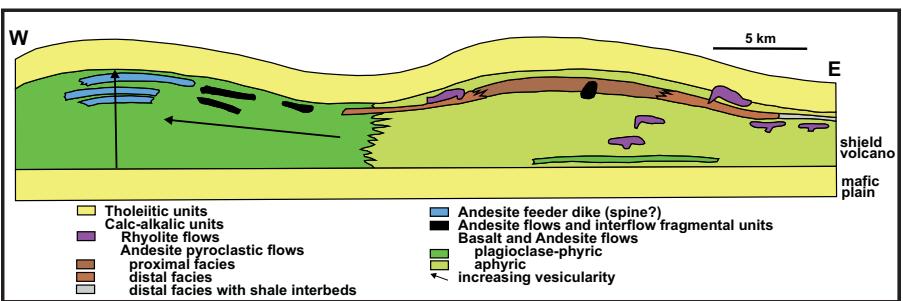

Figure 5. Mafic plain stratigraphy (after Thurston and Ayres 2004).

dated by flow inflation (Dann 2001; Hill 2001) in an ordered process of flow advance, inflation and endogenous growth. The relationship between komatiite volcanology and komatiite-associated mineralization is discussed in a subsequent section.

Komatiitic and/or basaltic flows, particularly at magma clan transitions, are commonly capped by thin, cm-scale argillite units. A deep water environment is suggested by the rarity of oxide-facies iron-formation, vesicular flows, hyaloclastite units (Dimroth et al. 1985) and mafic pyroclastic units. Lava plains and shield volcanoes dominated by mafic volcanism represent the normal base of greenstone belt stratigraphic sequences. They form 5-7 km-thick subaqueous plains $100-150 \mathrm{~km}$ in length consisting of overlapping shield volcanoes $>25 \mathrm{~km}$ in diameter (Dimroth and Rocheleau 1979; Thurston and Chivers 1990; Fig. 5). Shield volcanoes of the Abitibi greenstone belt are up to $7 \mathrm{~km}$ thick and $>30 \mathrm{~km}$ in diameter (Leclerc et al. 2011). Similar features are seen in mafic sequences in the Pilbara (Kiyokawa and Taira 1998; Krapez and Eisenlohr 1998), the Yilgarn (Brown et al. 2002), and the Baltic (Kozhevnikov 1992) cratons.

The shield volcanoes typifying mafic plain volcanism are succeeded by subaqueous composite volcanoes with steeper dips and higher proportions of pillowed flows, hyaloclastites, and vesicularity, perhaps related to a shallowing-upward depositional environment, e.g. the Monsabrais area in the Blake River Group of the Abitibi greenstone belt (Dimroth et al. 1974; Ross et al. 2008). Flow-foot breccias form prograding deltas typical of a littoral environment (Dimroth et al. 1985) and are consistent with a shallowing-upward hypothesis. Sheets of massive lava-forming topsets and foresets, which grade both upward and downward into pillow lava and pillow breccia, also suggest a littoral environment.

These sequences are linked to 'deep' water solely on the basis of the presence of textures such as pillows that are diagnostic of submarine deposition, and the fact that the geometry and thickness of the volcanic edifices require at least a few hundred metres of water depth. Pyroclastic and volcaniclastic units can likewise represent a broad range of depths. This caveat is applicable to the discussion in the following sections.

\section{Deep-Water Bimodal Volcanic Sequences}

The bimodal sequences consist of up to $90 \%$ basalt or basaltic andesite, and subordinate felsic volcanic rocks. Volcanologically, the mafic component is marked by the transition from shield volcanoes that erupted mafic lavas, to composite volcanoes having multiple vents (Lafrance et al. 2000), volcanic 


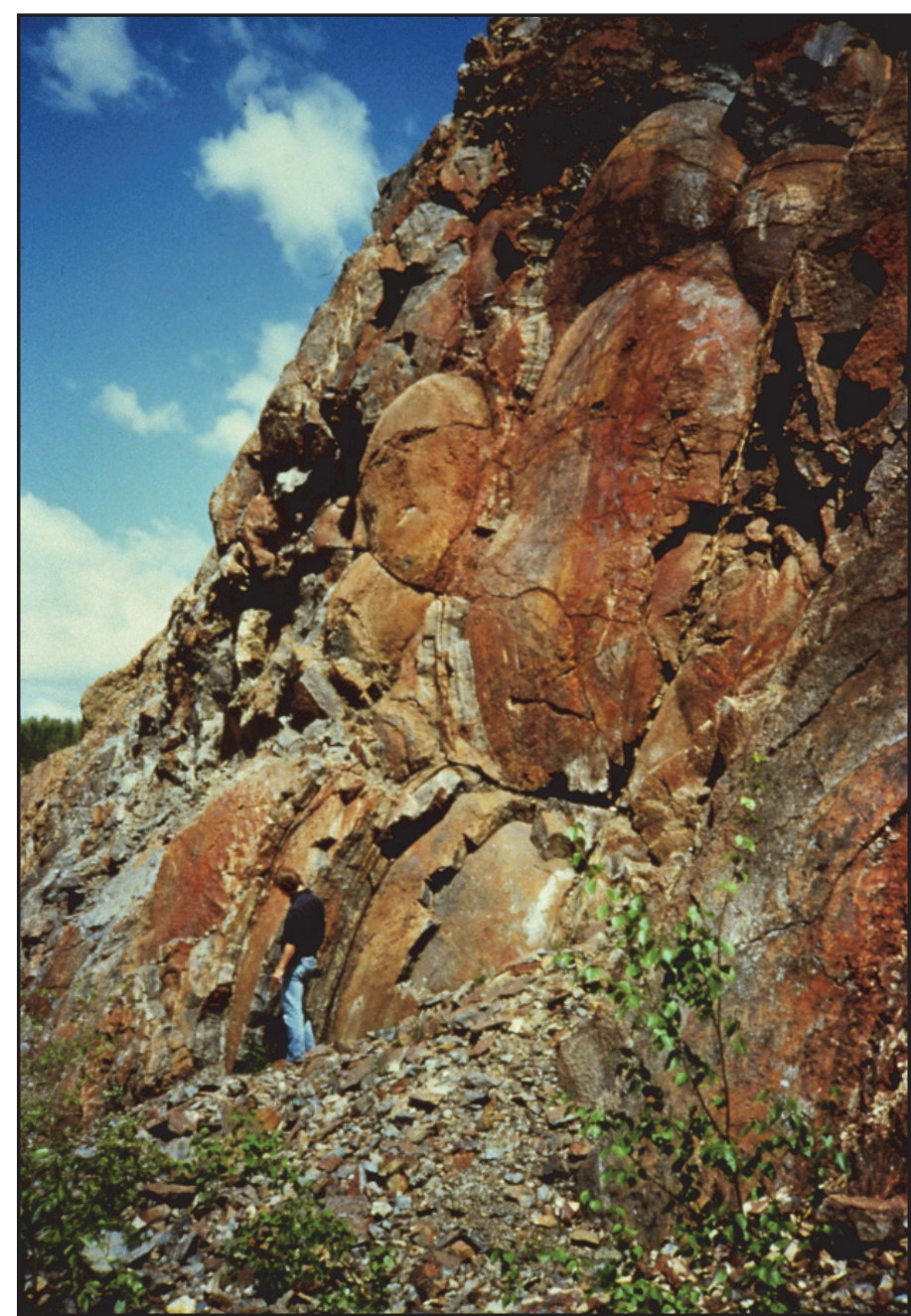

Figure 6. Domical stromatolites at the Steeprock mine, Marmion Terrane. Photo from stromatolites.blogspot.ca.

complexes (Legault et al. 2002), calderas and/or cauldrons (Gibson and Watkinson 1990) and small felsic centres formed along major structures (Scott et al. 2002). In this style of volcanism, the edifices were predominantly submerged, but shortterm emergence is recorded in the upper parts of these sequences (Thurston 1980; Lambert et al. 1990), as well as shallow-water features such as stromatolite-bearing carbonate rocks in the Abitibi greenstone belt (Hofmann and Masson 1994), the North Caribou terrane, at Steeprock in the Marmion terrane of the Superior Province (Hofmann et al. 1985; Stone et al. 1992; Fig. 6), and the Back River volcanic complex in the Slave Province (Lambert et al. 1990, 1992). Further constraints on water depth are absent.

Two main types of felsic rocks occur in deep-water bimodal sequences: 1) lava flows, domes, and related autoclastic units (de Rosen-Spence 1976; de Rosen-Spence et al. 1980); and 2) volcaniclastic units, including pyroclastic rocks possibly associated with calderas (Ross and Mercier-Langevin 2014). Some volcaniclastic units are interpreted as welded to nonwelded pyroclastic flows (Thurston et al. 1985), mass flows (lahars), and air fall eruptives (Hallberg 1986; Barley 1992;
Krapez and Eisenlohr 1998). Subaqueous pyroclastic flows have been proposed for calderas at Sturgeon Lake in the western Wabigoon subprovince (Morton et al. 1991), for the Selbaie and Noranda calderas in the Abitibi greenstone belt (Larson and Hutchinson 1993), in the Pilbara greenstones (Van Kranendonk 2000), and for subaerial welded ignimbrites in the North Caribou terrane (Thurston 1980).

Stratigraphically, the bimodal sequences are characterized by a mafic base and minor felsic volcanic rocks at the top (Fig. 7). The transition to the next volcanic cycle is marked by numerous mafic dikes cutting the felsic rocks, followed by mafic flows; alternatively, the felsic volcanic rocks are overlain by a 'sedimentary interface zone' (Thurston et al. 2008) characterized by clastic and chemical sedimentary rocks from a few $\mathrm{cm}$ to $\sim 500 \mathrm{~m}$ thick.

\section{Subaerial to Emergent Successor Basins}

The deep-water bimodal successions are succeeded by unconformably overlying successor basins deposited synorogenically and characterized by the first appearance of plutonic detritus and calc-alkaline to alkaline volcanic rocks. These units are classically termed 'Timiskaming'-type sequences in Canada (Gunning and Ambrose 1939; Fig. 8). Examples are found in all Archean cratons. In the Superior Province, examples include the Wabigoon (Ayer and Davis 1997), the Abitibi (Mueller and Dimroth 1987; Dostal and Mueller 1992) and the North Caribou (Parks et al. 2006) terranes. They also occur in the Slave (Mueller and Corcoran 2001), the Pilbara (Krapez and Barley 1987) and the Yilgarn (Swager et al. 1990) cratons. The successor basins contain up to $40 \%$ volcanic units (Swager et al. 1990; Mueller and Corcoran 1998), ranging in composition from calc-alkaline to shoshonitic. Shoshonites ${ }^{2}$ are found at Oxford Lake in the Oxford-Stull terrane (Brooks et al. 1982), in the Wawa-Abitibi terrane (Capdevila et al. 1982) and at Lake of the Woods in the western Wabigoon terrane (Ayer and Davis 1997). These successor basin volcanic rocks include 2-30 m-thick pillowed tholeiitic basalts and subaerial, calc-alkaline, felsic lobate and brecciated flows at Stormy Lake (Mueller and Corcoran 1998), and, at Kirkland Lake in the Abitibi greenstone belt, ultrapotassic lava flows with blocky or aa flow texture accompanied by pyroclastic surge and air fall deposits containing accretionary lapilli (Cooke 1966).

\section{VOLCANIC GEOCHEMISTRY AND PETROGENESIS}

\section{Introduction}

Volcanic rocks in Archean greenstone belts consist of two major geochemical associations, each typically making up one assemblage: 1) komatiite-tholeiite sequences (Sun and Nesbitt 1978; Arndt and Nesbitt 1982; Polat et al. 1998; Kerrich et al. 1998); and 2) bimodal basalt to dacite/rhyolite sequences (Condie 1981; Thurston et al. 1985; Laflèche et al. 1992). Basalts of the latter association vary from tholeiitic to calcalkaline, and more recent work (Wyman et al. 2000; Polat and Kerrich 2001; Hollings 2002) has shown that magnesian andesites, Nb-enriched basalt/andesite, and adakites common- 


\section{Lower Formational Stage}
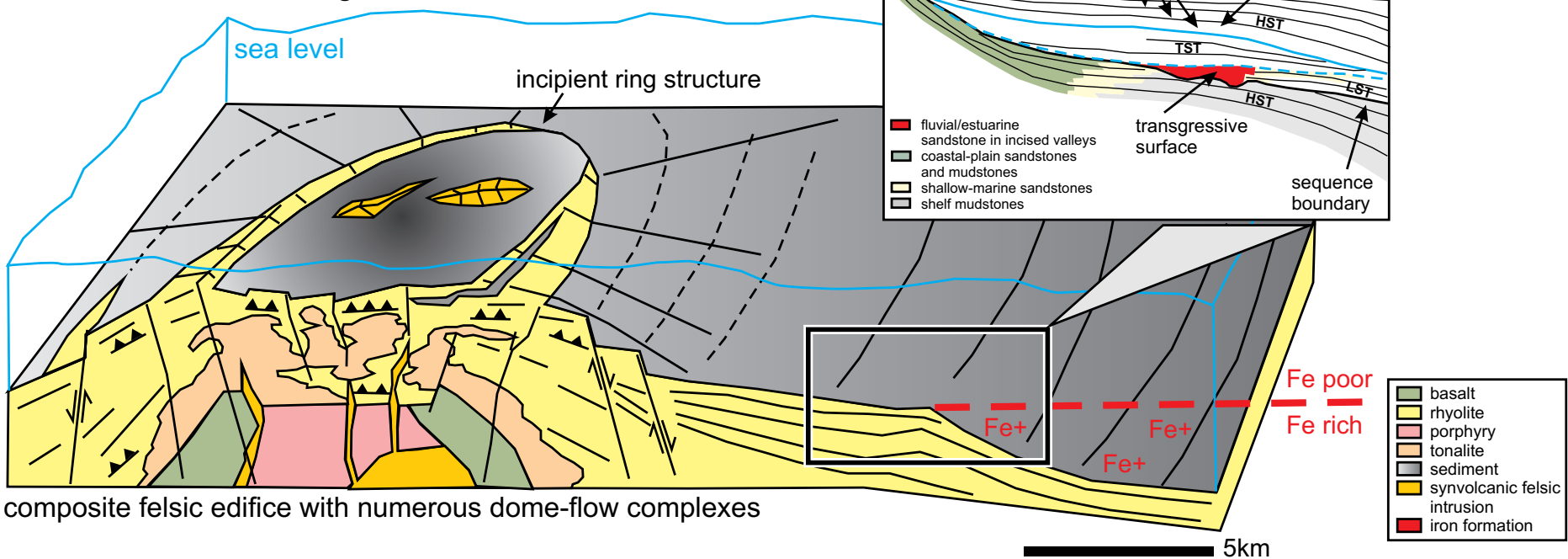

Upper Formational Stage

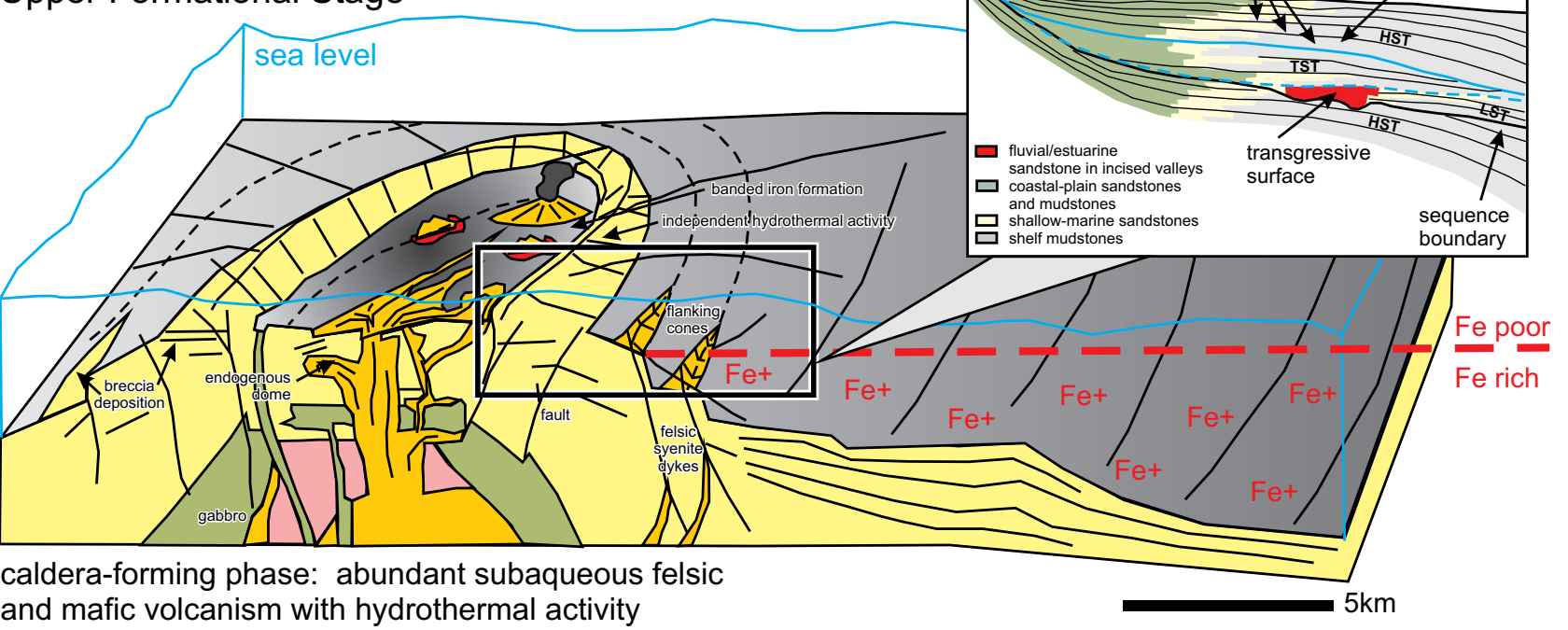

Figure 7. Stylized view of subaqueous calderas in bimodal associations of the Abitibi greenstone belt (after Mueller and Mortensen 2002; Thurston et al. 2008).

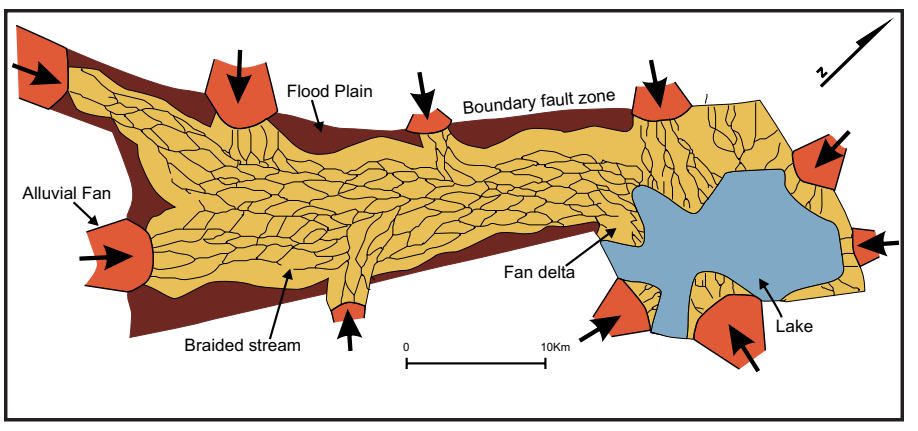

Figure 8. Diagrammatic view of an Archean successor basin prior to deformation (after Krapez and Barley 1987).

ly occur in the upper units of this association. Archean volcanic rocks have been subject to hydrothermal as well as metamorphic alteration. Conventionally, alteration is identified by volatile contents over 3.8\% and presence of normative corundum (Gélinas et al. 1977), and various alteration indices such as the Ishikawa index (Ishikawa et al. 1976) or the alteration box plot of Large et al. (2001). Within individual lava flows, a uniformity of inter-element ratios such as $\mathrm{Al}_{2} \mathrm{O}_{3} / \mathrm{TiO}$, $\mathrm{Ti} / \mathrm{Zr}$, and $\mathrm{Ti} / \mathrm{Sc}$ indicate a lack of large-scale mobility of some elements during alteration (Kerrich and Wyman 1996). General experience with trace element geochemistry has shown that on the extended trace element diagram ('spidergram') the large ion lithophile elements (LILE), Cs, Rb, Ba, and U can show erratic behaviour because of alteration, and therefore they are commonly omitted on plots of Archean volcanic rocks. In the following paragraphs, the geochemistry of the two sequence types is discussed. This is followed by a discussion of the implications of stratigraphic geochemical variations in selected Archean greenstone belts.

\section{Komatiite-Tholeiite Sequences}

Komatiite-tholeiite sequences consist of intercalated komatiitic and tholeiitic flows, and rare volcaniclastic units. Komatiites include ultramafic volcanic and coeval intrusive rocks, and are classified on the basis of $\mathrm{Al}_{2} \mathrm{O}_{3} / \mathrm{TiO}_{2}$ and $\mathrm{Gd} / \mathrm{Yb}_{\mathrm{CN}}(\mathrm{cN}=$ chondrite-normalized) (Table 1). By definition, they have $>18 \% \mathrm{MgO}$, high concentrations of $\mathrm{Ni}$ and $\mathrm{Cr}$, and $\mathrm{FeOt}$ about $11 \%$. The geochemistry of komatiites is a function of: 
Table 1. Petrogenetic classification of komatiites (after Sproule et al. 2002).

\begin{tabular}{lllll}
\hline \hline Geochemical Type & Al undepleted (AUK) & Al depleted (ADK) & Ti enriched & Ti depleted \\
\hline Type area & Munro & Barberton & Finland & Shining Tree \\
$\mathrm{Al}_{2} \mathrm{O}_{3} / \mathrm{TiO}_{2}$ & $15-25$ & $<15$ & $<15$ & $15-25$ \\
$\mathrm{Gd} / \mathrm{Yb}$ & $\sim 1$ & $1.2-2.8$ & $>1.2$ & $0.6-0.8$ \\
Degree of partial melting & $30-50 \%$ & $20-40 \%$ & $>20 \%$ & $20-50 \%$ \\
Depth of melt separation & Plume head: 2-8 Gpa & Plume tail: 6-9 Gpa & Plume head: 2-8 Gpa & Plume tail: 6-9 Gpa \\
\hline
\end{tabular}

1) source composition; 2) conditions of melting; 3) melting mechanisms; 4) extent and type of contamination; 5) degree of fractionation or accumulation; and 6) post-crystallization modification (Ludden et al. 1986; Xie et al. 1993). Komatiites are considered to be the product of mantle plumes, based upon thermodynamic models, experimental petrology, melt inclusions, trace element systematics, and the presence of comparable rocks on oceanic plateaux and oceanic hotspots (Storey et al. 1991; Herzberg 1992; McDonough and Ireland 1993; Kerr 1996). Most Archean plumes were derived from depleted mantle (Campbell et al. 1989; Storey et al. 1991) that was tapped at various depths, as summarized in Table 1 . It is interesting to note that Al-depleted and Al-undepleted komatiites are intercalated in the south-central part of the Abitibi greenstone belt, suggesting a rising plume source (Dostal and Mueller 1997). The major modern analogue to Archean komatiites is the Gorgona komatiite at the base of the Columbia-Caribbean Large Igneous Province (Kerr 1996). A contrasting view suggests that komatiites originated as hydrous magmas (Grove and Parman 2004), possibly in a subduction zone setting (Parman et al. 2001); however, as indicated by Arndt et al. (2008, p. 349), this hypothesis is not widely supported.

Komatiitic basalts have $\mathrm{MgO}$ contents of $18-26 \%$ and relatively low abundances of $\mathrm{TiO}_{2}(<1 \%)$ and incompatible trace elements (Arndt et al. 2008). They have lower contents of Fe, high-field-strength elements (HFSE) and light rare-earth elements (LREE) than tholeiites (Arndt et al. 2008). Trace elements indicate that Archean basalts associated with komatiites are predominantly $\mathrm{Mg}$ - to Fe-tholeiites displaying flat REE patterns (Fig. 9). On the basis of their consistent stratigraphic association with komatiites and picrites, the tholeiites are interpreted as products of a rising plume head that entrained some of the surrounding mantle (Campbell et al. 1989; Arndt 1991). These tholeiites therefore represent a mixture of plume head material and upper mantle melts (Campbell et al. 1989; Arndt 1991). Archean basalts display a continuous trend from high to low $\mathrm{Mg \#}$ accompanied by a rise in $\mathrm{FeOt}, \mathrm{Nb}$, Th, Zr, Hf, REE and $\mathrm{Y}$, accompanied by decreasing $\mathrm{Cr}$ and $\mathrm{Ni}$ contents (Kerrich et al. 1999). In general terms, Archean basalts have higher Fe contents than younger counterparts, clearly seen on an Fe/Ti vs. Al/Ti cation diagram (Francis et al. 1999; Fig. 10). The tholeiites within komatiite-tholeiite sequences are commonly divided into $\mathrm{Mg}$ - and Fe-tholeiites and LREE-enriched units (Maurice et al. 2009). A recently developed subdivision applied on a regional scale consists of $\mathrm{Mg}$-tholeiites with 4-10\% $\mathrm{MgO}$, 9-15\% $\mathrm{Fe}_{2} \mathrm{O}_{3} \mathrm{t}$, and $0.4-1.2 \% \mathrm{TiO}_{2}$, and Fe-tholeiites
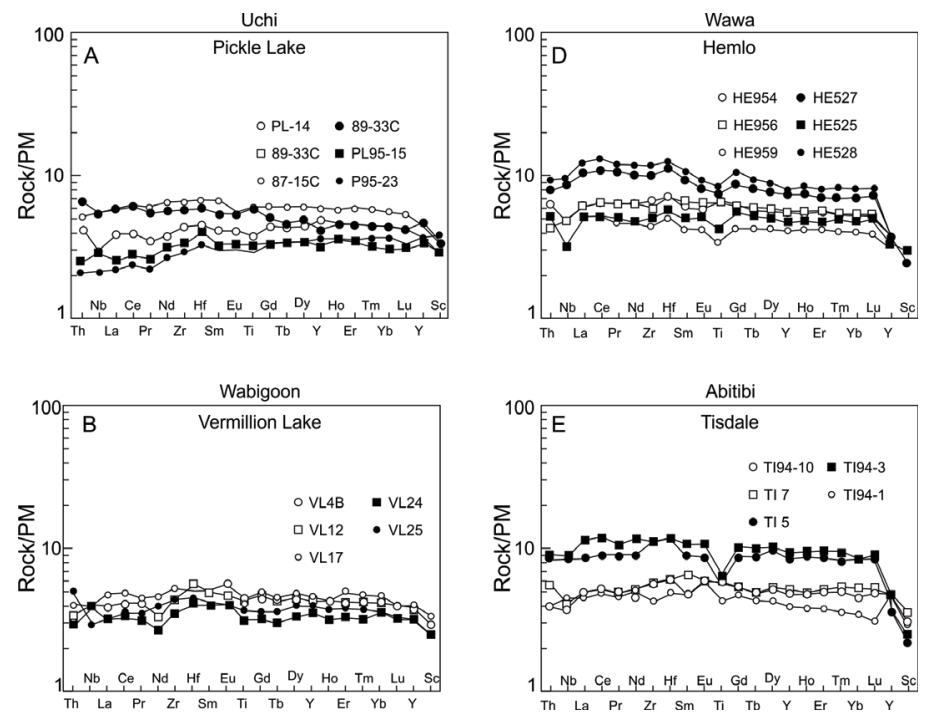

Figure 9. Representative primitive mantle-normalized extended trace element diagrams of Archean tholeiites from the Superior Province (after Kerrich et al. 1999). Normalization to primitive mantle values of Sun and McDonough (1989).

having a similar range of $\mathrm{MgO}$ content, but higher $\mathrm{Fe}_{2} \mathrm{O}_{3} \mathrm{t}$ $(11-20 \%)$, and $\mathrm{TiO}_{2}(1.0-2.6 \%)$. The Fe-tholeiites contain greater abundances of incompatible trace elements (e.g. 50-155 ppm Zr), lower $\mathrm{Al}_{2} \mathrm{O}_{3} / \mathrm{TiO}_{2}(<15)$, and higher $\mathrm{Gd} / \mathrm{Yb}_{\mathrm{CN}}$ (1.2-2.0) (Maurice et al. 2009).

Kerrich et al. (1999), in discussing the origin of Archean tholeiites and komatiites from the Abitibi and the Lumby Lake greenstone belts, dismiss the possibility of contamination affecting trace element geochemistry on the basis of: 1) the lack of geochemical signatures of contamination; 2) the lack of xenocrystic zircons; and 3) the lack of isotopic evidence for contamination. All of these criteria have subsequently been disproven in at least part of the Wawa-Abitibi terrane and the Marmion terrane of the Superior Province (Thurston 2002; Ayer et al. 2005; Buse et al. 2010). The probability of contamination is inherent in the autochthonous development of many other Superior Province greenstones (Thurston 2002). The notion that magmas in granite-greenstone terranes transect older units is supported by the presence of dikes of younger greenstones cutting older greenstones in the North Caribou terrane (Rogers et al. 2000) and the Wawa-Abitibi terrane (Ayer et al. 2005). Xenocrystic zircons in Archean greenstones have been found in about $20 \%$ of post-millennial geochronological studies, which have been carried out mainly in the Wawa-Abitibi terrane and in the Marmion terrane of the Superior Province (Buse et al. 2010). 


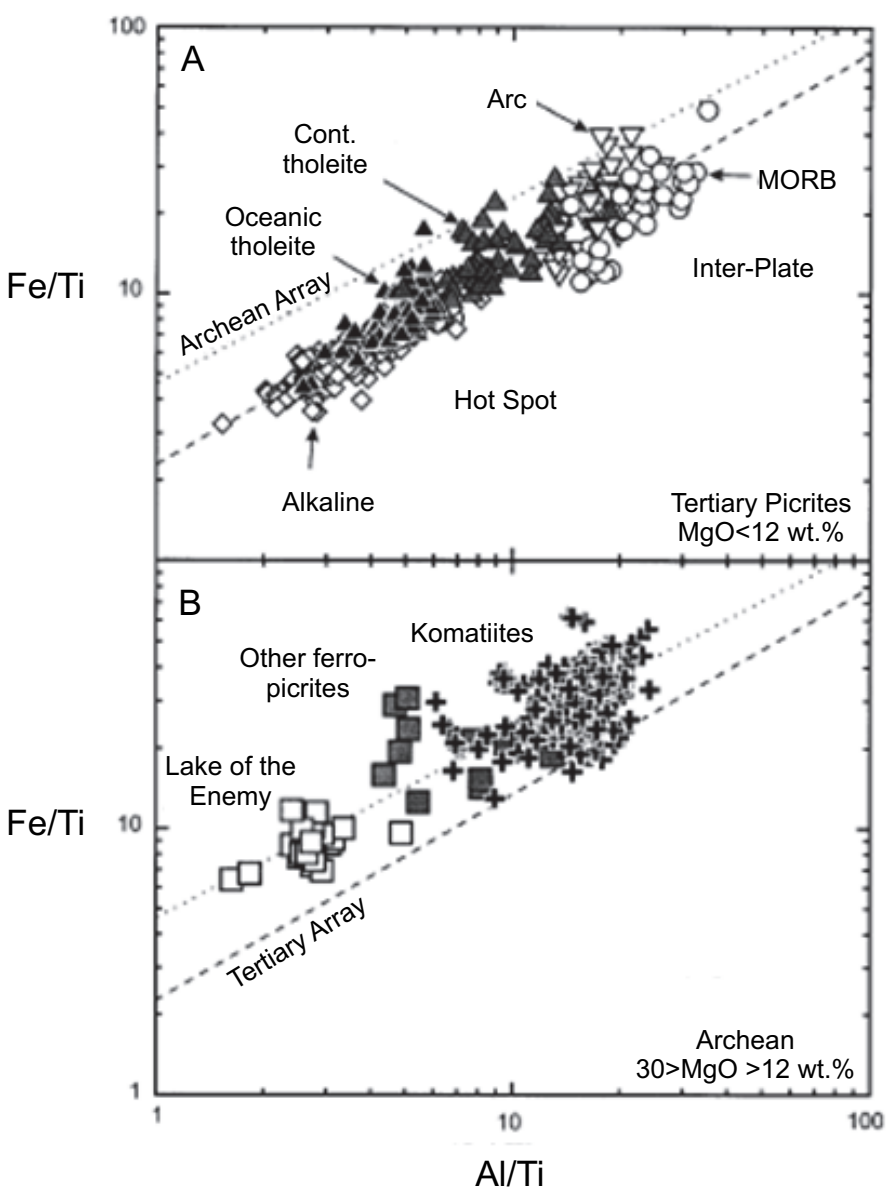

Figure 10. Plot of $\mathrm{Fe} / \mathrm{Ti}$ vs. $\mathrm{Al} / \mathrm{Ti}$ (each in wt. percent) demonstrating the high $\mathrm{Fe}$ nature of Archean mantle, as shown in the chemistry of Archean picritic lavas (Francis et al. 1999).

The advent of ICP-MS analysis has brought about many studies of the trace element geochemistry of Archean volcanic rocks and possible relationships with geodynamic settings (Hollings and Kerrich 1999, 2002; Hollings et al. 1999a, b; Kerrich et al. 1999; Wyman and Kerrich 2009). For example, in northwestern Ontario, Hollings et al. (1999b) have documented basalt geochemistry in 2.9-3.0 Ga komatiite-tholeiite sequences (Fig. 11). They observed that the majority of basalts are $\mathrm{Mg}$-tholeiites with flat REE patterns. However, some samples display negative $\mathrm{Nb}$ anomalies, $\mathrm{La} / \mathrm{Sm}_{\mathrm{CN}} 1.8-3.4$, and $\mathrm{Gd} / \mathrm{Yb}_{\mathrm{CN}}$ 1.0-1.6; some samples display LREE depletion. Many of the northwestern Ontario greenstone belts examined in this study are underlain by older greenstone and granitoid rocks. In support of this, it was noted that $\mathrm{Nb}$ anomalies increase with increasing $\mathrm{SiO}_{2}, \mathrm{La} / \mathrm{Sm}_{\mathrm{CN}}$, and $\mathrm{Th} / \mathrm{Ce}_{\mathrm{CN}}$, all suggestive of contamination by a felsic component, given the high $\mathrm{La} / \mathrm{Sm}_{\mathrm{CN}}$ and $\mathrm{Th} / \mathrm{Ce}_{\mathrm{CN}}$ of granitoid magmas. The so-called Siliceous High Magnesium Basalts (SHMB) documented in the Archean of Australia and elsewhere (Sun et al. 1989) have similar high $\mathrm{SiO}_{2}(51-55 \%)$ and $\mathrm{MgO}(10-16 \%)$, and are shown to be produced by contamination, as validated by $\mathrm{Pb}$ and $\mathrm{Sm}-\mathrm{Nd}$ isotopic and trace element studies.

\section{Boninites}

Boninites are primitive andesites occurring within komatiite-tholeiite sequences. They contain $>53 \% \mathrm{SiO}_{2}, 8-15 \%$

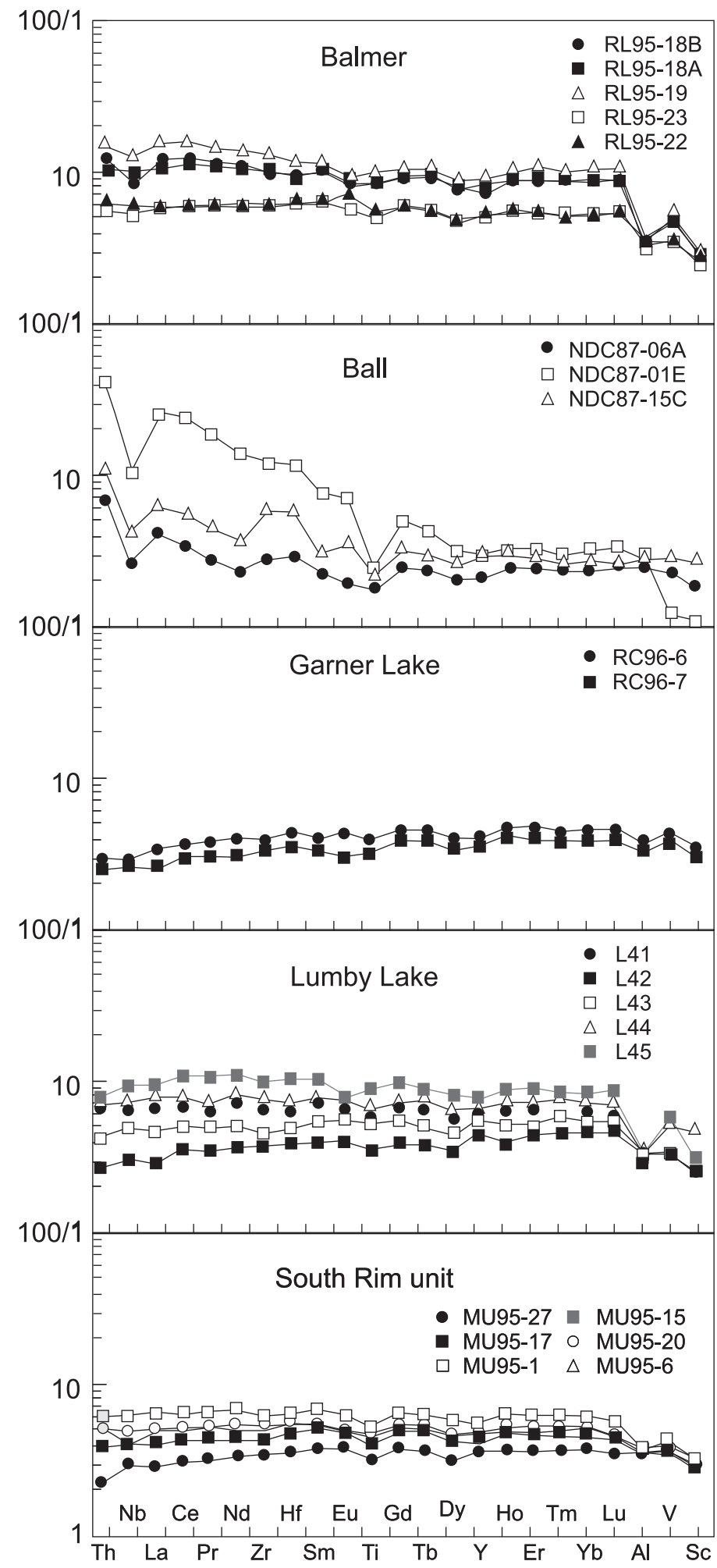

Figure 11. Tholeiitic and komatiitic volcanic rocks from greenstone belts of the northern Superior Province (Hollings et al. 1999). A. Tholeiitic flows from the $\sim 3$ Ga Balmer assemblage, Red Lake greenstone belt; B. Tholeiitic flows from the $\sim 3$ Ga Ball assemblage, Red Lake greenstone belt; C. Tholeiitic flows from Garner Lake in the Rice Lake greenstone belt of the Bird River terrane; D. Tholeiites from the Lumby Lake greenstone belt of the Marmion terrane; and E. Tholeiites from the $\sim 3$ Ga South Rim assemblage of the North Caribou greenstone belt (shown in Figure 3). Data are normalized to the primitive mantle values of Sun and McDonough (1989). 
$\mathrm{MgO}, \mathrm{Mg} \#>60$, low $(<0.5 \%) \quad \mathrm{TiO}_{2}$, enrichment in LREE compared to tholeiites, and fractionated HREE (Crawford et al. 1989; Fig. 12). Representative Archean boninites (Kerrich et al. 1998) are characterized by $\mathrm{Gd} / \mathrm{Yb}_{\mathrm{CN}} 0.3-0.7, \mathrm{Zr} / \mathrm{Y}$ 1.2-1.7, positive $\mathrm{Zr}$ and $\mathrm{Hf}$ anomalies, $\mathrm{Zr} / \mathrm{Hf}>36$, LREE depletion to enrichment $\left(\mathrm{La} / \mathrm{Sm}_{\mathrm{CN}} 0.72-1.40\right)$, and negative $\mathrm{Nb}$ anomalies $\left(\mathrm{Nb} / \mathrm{La}_{\mathrm{PM}} 0.76-0.93\right.$; рм $=$ primitive mantle-normalized; Fig. 12). Boninite petrogenesis is a two-stage process, beginning with extraction of a melt from the mantle and leaving a refractory residue that is fluxed by fluids enriched in Si, Na, LILE, \pm LREE, and in some instances $\mathrm{Zr}$ and Hf. This two-stage process generates the variably enriched or depleted LREE pattern, and the negatively fractionated HREE of boninites and lowTi tholeiites (Crawford et al. 1989). In the Phanerozoic, boninites have been reported from ophiolites, intraoceanic arcs, back arcs, forearcs, continental margin settings, and intra-continental rifts (Kerrich et al. 1998, and references therein). Boninites in the Abitibi greenstone belt are associated with komatiites and tholeiites. Boninites are noted also in the Yilgarn (Angerer et al. 2013), Pilbara (Smithies 2002), and Baltic (Shchipansky et al. 2004) cratons. Kerrich et al. (1998) favour a petrogenesis for the Abitibi boninites involving derivation from a depleted mantle source rather than the second-stage petrogenesis involving fluid fluxing of a depleted source. In more detail, the association with komatiites and a progression from primitive tholeiites to more evolved tholeiites is considered by Kerrich et al. (1998) to represent interaction of plume-derived komatiites and basalts with subduction zone-derived tholeiites.

Archean boninites are more aluminous, slightly less depleted in the heavy REEs, and have higher $\mathrm{TiO}_{2}$ contents than Phanerozoic analogues (Bédard et al. 2013). Given the variety of geodynamic settings of boninites, the only common thread is derivation from a depleted source, with or without fluid fluxing. However, it must be kept in mind that Archean boninites are exceedingly rare, and only a few tens of analyses exist, a function of rarity or perhaps a lack of recognition by investigators other than specialized petrologists. The above-cited studies provide some data on location, but stratigraphic position and primary structures are not described in all the cited studies. Excellent petrographic detail is presented by Wyman and Kerrich (2012) for boninites in the Youanmi terrane of the Yilgarn craton. The consistent features of their petrogenesis are high-temperature melting and derivation from depleted mantle. These komatiite-tholeiite sequences are distinct from more evolved basalt - andesite sequences such as the Blake River Group of the Abitibi greenstone belt, which are characterized by LREE enrichment and negative $\mathrm{Ti}, \mathrm{Nb}$ and $\mathrm{Eu}$ anomalies (Ayer et al. 2005). Geochemically similar rocks have been considered to originate by crustal contamination of komatiitic material (e.g. Sylvester et al. 1997).

\section{Ferropicrites}

Ferropicrites are ultramafic rocks having $\mathrm{MgO}$ contents similar to komatiites $(>18 \% \mathrm{MgO})$ but lower $\mathrm{Al}_{2} \mathrm{O}_{3}(<10 \%$ to $<5 \%$ ); they are defined as ferropicrites based on FeOt $>14 \%$ (Hanski and Smolkin 1989). The $\mathrm{Al}_{2} \mathrm{O}_{3}$ content remains relatively constant with increasing $\mathrm{MgO}$, and $\mathrm{Al}_{2} \mathrm{O}_{3} / \mathrm{TiO}_{2}$ values are $\sim 4$; these characteristics are similar to moderately alkaline olivine basalts associated with hotspots. On the classification diagram for ultramafic rocks (Hanski et al. 2001), the Superior Province ferropicrites fall between the picrite and the $\mathrm{Al}$ depleted picrite fields. They are enriched in $\mathrm{TiO}_{2}(1-2 \%)$ and HFSE (e.g. $\mathrm{Nb}=10-17 \mathrm{ppm}, \mathrm{Nb} / \mathrm{La}_{\mathrm{CN}}=0.8-1.3$ ) relative to komatiites, and display fractionated $\mathrm{REE}$ profiles $\left(\mathrm{La} / \mathrm{Yb}_{\mathrm{CN}}=\right.$ 8-18; Goldstein and Francis 2008) and HREE depletion $\left(\mathrm{Gd} / \mathrm{Yb}_{\mathrm{CN}} \sim 3\right.$; Fig. 13A). Furthermore, they have higher ratios of some incompatible elements (e.g. $\mathrm{Zr} / \mathrm{Y} \sim 6$ ). Given these differences from komatiites, ferropicrites require a distinct petrogenesis (Goldstein and Francis 2008). In support of this, a

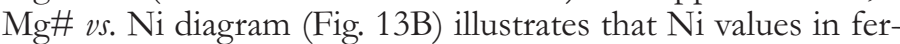
ropicrites rise asymptotically at $\mathrm{Mg \#} \mathrm{83,} \mathrm{whereas} \mathrm{for} \mathrm{komati-}$ ites the rapid rise is at $\mathrm{Mg \#} 90$ (Goldstein and Francis 2008). Thus, sources for ferropicrite magmas have lower $\mathrm{Mg} \#$ values than komatiite source mantle, indicating that they are distinct. Ferropicrites contain higher Ni but lower $\mathrm{Cr}$ than komatiites, indicating higher normative olivine in ferropicrites in contrast to the importance of normative pyroxene in komatiites.

Ferropicrites have liquidus temperatures similar to komatiites, but their source was olivine-rich mantle that, compared to komatiites, was enriched in incompatible trace elements (Goldstein and Francis 2008). Postulated petrogenetic mechanisms for this suite include liquid immiscibility, mixing of an Fe-rich immiscible liquid with a komatiitic liquid, melting of isolated enriched mantle domains, melting of a peridotite-basalt mixture, or melting of an Fe-rich mantle source that was depleted 

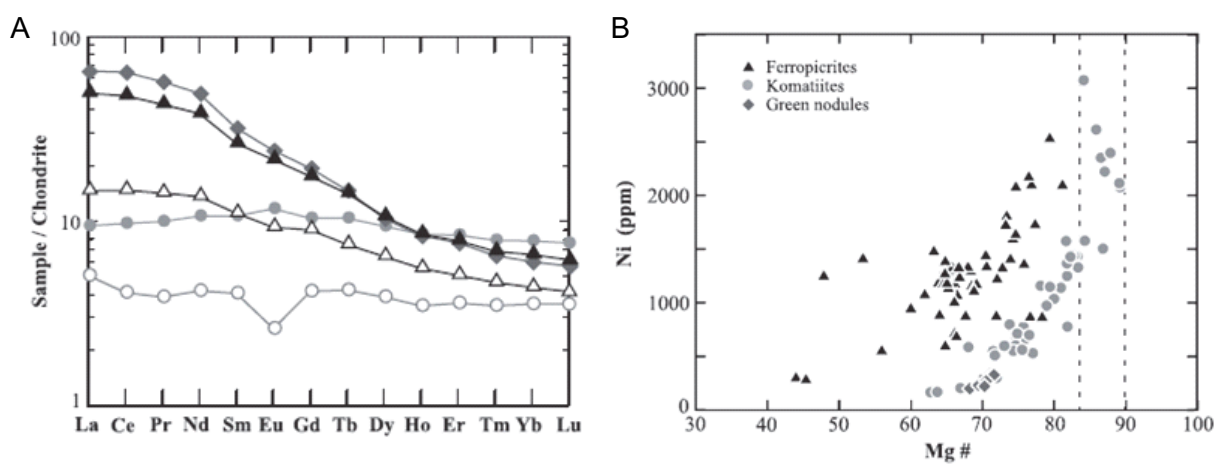

Figure 13. Ferropicrites in greenstone belts. A. REE profiles for an average pyroclastic ferropicrite, ferropicritic intrusive rocks, fine-grained spinifex and chilled margins of komatiitic flows, samples of cumulate zones of komatiitic flows, and green nodules normalized to CI chondrites. Solid triangles: pyroclastic ferropicrites, open triangles: intrusive ferropicrites, solid circle: fine-grained spinifex and chilled margins, open circles: cumulate zones of komatiites, and diamond symbol: green nodules. (after Goldstein and Francis 2008, their figure 5). B. Illustrating the varying $\mathrm{Ni} v$ s. $\mathrm{Mg} \#$ systematics of komatiites and ferropicrites (after Goldstein and Francis 2008, their figure 12).

relative to CHUR (chondritic uniform reservoir) (Goldstein and Francis 2008). Such a melt would have the fractionated REE patterns seen in Archean ferropicrites. In the end, the favoured model is one in which an olivine-rich mantle source is melted at $\sim 5 \mathrm{Gpa}$ (Goldstein and Francis 2008).

Ferropicrites are spatially associated with komatiite-tholeiite sequences within greenstone belts of the Wawa-Abitibi terrane (Green and Schulz 1977; Stone et al. 1995; Goldstein and Francis 2008), the Kolar schist belt of India (Rajamani et al. 1985), and the Lake of the Enemy terrane in the Slave Province (Francis et al. 1999). More recently, they have been reported in the Marmion terrane at Steeprock Lake, at Lumby Lake, and Grassy Portage Bay in the western Wabigoon terrane (Goldstein and Francis 2008). The Marmion terrane occurrences were also described as Al-depleted komatiites (Hollings and Wyman 2000). Ferropicrites may occur either as typical subaqueous pillowed flows (Francis et al. 1999), pyroclastic rocks (Steeprock Lake, Lumby Lake and Grassy Portage Bay) or as intrusive plugs (Dayohessarah Lake; Goldstein and Francis 2008). The western Superior Province ferropicrites of Goldstein and Francis (2008) are somewhat higher in $\mathrm{MgO}$ $(\sim 19 \%)$ compared to those referred to above from Minnesota, Boston Township (in the Abitibi greenstone belt) and India. However, the western Superior Province ferropicrites have similar trace element patterns.

\section{Bimodal Tholeiitic to Calc-Alkaline Basalt-Dacite/ Rhyolite}

The bimodal basalt-dacite association occurs in many of the greenstone belts of the Superior Province and most other Archean cratons. Basalts and basaltic andesites of the bimodal association generally display flat REE patterns and typically contain ca. 5\% MgO, whereas FeOt increases $~ 5 \%$ up to a maximum of 18-20\% (Thurston and Fryer 1983; Jensen 1985; Thurston et al. 1985). There is a continuous transition from tholeiites with flat REE patterns to calc-alkaline basalts with fractionated REE patterns (Leclerc et al. 2011; Bédard et al. 2013). A typical suite from the Schreiber-Hemlo and White River-Dayohessarah greenstone belts of the Wawa-Abitibi terrane is characterized by $\mathrm{Mg}$ - to Fe-tholeiites having $\mathrm{La} / \mathrm{Yb}_{\mathrm{CN}}=2.7-24.5$ (Polat et al. 1998). In the bimodal associ- ation, andesites in general are not prominent (Taylor and McLennan 1985; Condie 1986), where present, they vary from primary andesitic liquids to fractionated basalts (Thurston and Fryer 1983). In the Yilgarn craton, a fractionation sequence from basalt through andesite to rhyolite is reported for the Welcome Well and Marda complexes (Taylor and Hallberg 1977). In the Abitibi greenstone belt, primary andesites range from low- to high-K andesites (Ayer et al. 2005) using the classification of Gill (1981). The felsic endmembers of this association range from dacite to rhyolite. In terms of trace element geochemistry, these units display flat, 'tholeiitic' patterns through to extremely fractionated patterns (Thurston 1981; Lesher et al. 1986; Hart et al. 2004). This bimodal association is more fractionated than the komatiite-tholeiite association and has the negative $\mathrm{Ti}$ and $\mathrm{Nb}$ anomalies considered by some to represent arc petrogenesis (Hart et al. 2004). Similar features are seen in the Blake River Group of the Abitibi greenstone belt and throughout the Superior craton (Thurston et al. 1985; Scott et al. 2002).

Associated with the bimodal suite are a number of relatively unusual rock types for Archean greenstone belts: the socalled adakite suite, consisting of magnesian andesites, $\mathrm{Nb}$ enriched basalts and andesites, and adakites. Their geochemistry is discussed below. In modern arc systems, adakites, Nbenriched basalts and magnesian andesites are spatially and temporally associated (Kepezhinskas et al. 1995). For example, in Panama and Costa Rica, normal arc volcanic rocks are succeeded by an adakite $-\mathrm{Nb}$ enriched basalt association (Defant et al. 1992). The adakite suite is interrelated in the sense that their geochemical variation is a function of garnet fractionation (Richards and Kerrich 2007).

\section{Adakites}

Adakites, formerly termed tonalite-trondhjemite-granodiorite (TTG) series volcanic rocks (including low-K dacites) (Richards and Kerrich 2007), were defined by Defant and Drummond $(1990,1993)$ as a term for magnesian andesites and more felsic derivatives in the Aleutian arc, where they were interpreted to have formed by the melting of subducted oceanic crust. They are characterized by high $\mathrm{La} / \mathrm{Yb}$, high $\mathrm{Sr}$ $(\sim 1800 \mathrm{ppm})$, 'relatively high' Mg\#, Cr, and Ni (Richards and Kerrich 2007) compared to normal andesites, and non-radiogenic $\mathrm{Pb}$ and $\mathrm{Sr}$ isotopic compositions. Further details of the geochemistry of adakite-like rocks are listed in Table 2 . Archean volcanic rocks of this association are enriched in elements mobilized by aqueous fluids (e.g. $\mathrm{W}, \mathrm{Pb}, \mathrm{Be}, \mathrm{Li}$ ), whereas HFSE such as Ti, Nb and Ta are depleted. The central question is whether this geochemical signature is unique to the subduction environment or whether other geodynamic settings can produce the same features. Defant and Drummond (1990) used $\mathrm{Sr} / \mathrm{Y} v$ s. $\mathrm{Y}$ and $\mathrm{La} / \mathrm{Yb} v$ s. $\mathrm{Yb}$ binary plots to demonstrate the role of garnet fractionation in adakites $v s$. plagioclase fractionation typical of normal modern arc suites. The general term 'adakite' or adakitic has been used to describe Mg-rich 
Table 2. Adakite suite details.

\begin{tabular}{|c|c|c|c|}
\hline Rock type & Defining Characteristics & Examples & Petrogenesis \\
\hline Adakite & $\begin{array}{l}\mathrm{SiO}_{2}>56 \%, \mathrm{Al}_{2} \mathrm{O}_{3}>15 \% \\
\mathrm{MgO}<3 \%, \mathrm{Mg} \# \sim 5 \\
\mathrm{Y}<18 \mathrm{ppm}, \mathrm{Yb}<1.9 \mathrm{ppm}, \\
\mathrm{Ni}>18 \mathrm{ppm}, \mathrm{Cr}>30 \mathrm{ppm} \\
\text { High } \mathrm{La} / \mathrm{Yb} \\
\text { High } \mathrm{Sr} / \mathrm{Y} \\
\text { High } \mathrm{Mg} \#, \mathrm{Cr}, \mathrm{Ni} \\
\text { compared to normal }^{\text {andesites }}{ }^{1}\end{array}$ & $\begin{array}{l}\text { Superior Province: } \\
\text { Schreiber-Hemlo, White } \\
\text { River-Dayohessarah, } \\
\text { Winston L. - Big Duck L., } \\
\text { Manitouwadge }^{2} \text { NE } \\
\text { Quebec }^{3} \text {. } \\
\text { Baltic Shield }^{4} \text {, } \\
\text { Dharwar craton }^{5} \\
\text { N. China craton }\end{array}$ & $\begin{array}{l}\text { Evolution by garnet } \\
\text { fractionation. Generated } \\
\text { by slab melting OR by } \\
\text { MASH or AFC. }{ }^{1}\end{array}$ \\
\hline Nb-enriched basalts & $\begin{array}{l}\mathrm{Nb}>20 \mathrm{ppm}, \mathrm{Nb} / \mathrm{La}_{\mathrm{MN}}, \\
0.5-1.4 ;^{7}\end{array}$ & $\begin{array}{l}\text { Superior Province: } \\
\text { Wabigoon; North } \\
\text { Caribou }^{8-9} \text {; Pilbara }{ }^{10} \text {; } \\
\text { Dharwar }^{11}, \text { Baltic shield }^{4}\end{array}$ & $\begin{array}{l}\text { Lithospheric or } \\
\text { asthenospheric OIB in } \\
\text { source; small degree of } \\
\text { melting of a MORB } \\
\text { source in slab window; } \\
\text { adakitic metasomatism } \\
\text { above mantle wedge }\end{array}$ \\
\hline $\begin{array}{l}\text { Andesites and } \\
\text { Magnesian andesites }\end{array}$ & $\begin{array}{l}\text { High } \mathrm{MgO} \text { relative to } \mathrm{SiO}_{2} \\
\mathrm{Sr} / \mathrm{Y}>20^{1}\end{array}$ & $\begin{array}{l}\text { Northern part of Wawa- } \\
\text { Abitibi terrane }^{12}\end{array}$ & $\begin{array}{l}\text { Evolution by garnet } \\
\text { fractionation. Generated } \\
\text { by slab melting OR by } \\
\text { MASH or AFC }\end{array}$ \\
\hline
\end{tabular}

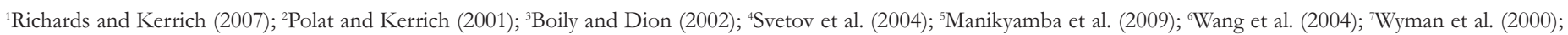
${ }^{8}$ Hollings and Kerrich (2000); ${ }^{9}$ Hollings (2002); ${ }^{10}$ Smithies et al. (2005); ${ }^{11}$ Kerrich and Manikyamba (2012); ${ }^{12}$ Ayer et al. (2010).

andesites, Nb-enriched basalts and andesites, and adakites (Polat and Kerrich 2001; Svetov 2001; Slabunov et al. 2006). Several other rock types in the basalt-rhyolite fractionation series share the high $\mathrm{La} / \mathrm{Yb}$, and high $\mathrm{MgO}, \mathrm{Cr}$ and $\mathrm{Ni}$ of adakites, such as high-Mg andesites and $\mathrm{Nb}$-enriched basalts in modern arcs (Sajona et al. 1996). However, Richards and Kerrich (2007) show that Melting-Assimilation-StorageHomogenization (MASH) (Hildreth and Moorbath 1988) or Assimilation-Fractional Crystallization (AFC; Depaolo 1981) processes that control tholeiitic and calc-alkaline magmas can also produce adakitic compositions. Therefore, although some authors appeal to subduction processes for the origin of the adakite suite, the MASH and AFC processes simply require a subjacent magma chamber; in this way, the high $\mathrm{La} / \mathrm{Yb}$ and $\mathrm{Sr}$ are hallmarks of petrogenesis involving mafic sources within the garnet stability field (Richards and Kerrich 2007). Alternatively, Johnson et al. (2014) modelled trace element distribution in a hotter Archean Earth and found that convergent plate margins are not necessary.

Adakite-like rocks occur in three magmatic associations in greenstone belts: 1) volcanic rocks and related minor intrusive bodies forming part of the bimodal association (Kerrich and Fryer 1979; Hollings and Kerrich 2000; Wyman et al. 2000; Polat and Kerrich 2001; Naqvi et al. 2006); 2) syn- to late-tectonic batholiths of the high-Al-TTG association, such as the Lake Abitibi and Round Lake batholiths of the Abitibi greenstone belt (Feng and Kerrich 1992); and 3) post-tectonic high$\mathrm{Mg}$ diorites/sanukitoids (Smithies and Champion 2000).

Adakites and related magnesian andesites and $\mathrm{Nb}$-enriched basalt-andesite are not common rock types within the bimodal association in Superior Province greenstone belts (Boily and Dion 2002; Percival et al. 2003; Ujike et al. 2007). Given the lack of stratigraphic detail in the papers describing these rocks in the Superior Province, it is not currently possible to understand how the adakitic rocks relate to greenstone chemostratigraphy. However, adakitic rocks occur as lava flows in the Superior Province, and as volcaniclastic rocks in the Baltic shield (upper part of the Hautavaara greenstone belt; Svetov et al. 2004).

\section{Magnesian Andesites}

Magnesian andesites in Archean greenstone belts have high $\mathrm{MgO}$ contents (e.g. 4.8\%) relative to $\mathrm{SiO}_{2}$ (Polat and Kerrich 2001), and high $\mathrm{Cr}$ and Ni. Thus, by definition, they plot above the divide between arc andesites and magnesian andesites on a $\mathrm{MgO}$ vs. $\mathrm{SiO}_{2}$ diagram (McCarron and Smellie 1998). Compared to normal andesites in the Abitibi-Wawa terrane, magnesian andesites contain lower $\mathrm{TiO}_{2}$ at a given $\mathrm{MgO}$ content, and tend to have higher $\mathrm{Th}$ and $\mathrm{Ce}$, lower $\mathrm{Nb}$, and nearly flat patterns for $\mathrm{Zr}, \mathrm{Y}$ and $\mathrm{Yb}$ with respect to $\mathrm{MgO}$. Magnesian andesites form a minor constituent of the ca. 2720 Ma greenstones on the northern fringe of the Wawa-Abitibi terrane west of the Kapuskasing structural zone (Ayer et al. 2010).

Magnesian andesites are interpreted to form through hybridization of adakitic liquids with peridotitic mantle wedge material, which explains their high $\mathrm{Mg}, \mathrm{Cr}, \mathrm{Ni}$, Th and $\mathrm{Ce}$, fractionated REE, low $\mathrm{Yb}$ content and negative $\mathrm{Nb}$ and $\mathrm{Ti}$ anomalies (Keleman 1995; Yogodzinski et al. 1995). Details on volcanology or stratigraphic association are not available. Examples of their trace element geochemistry in the Wawa-Abitibi terrane are shown in Figure 14.

\section{$\mathrm{Nb}$-Enriched Basalts}

$\mathrm{Nb}$-enriched basalts are LREE-enriched basalts containing $>20$ ppm $\mathrm{Nb}$ and $\mathrm{Nb} / \mathrm{La}_{\mathrm{CN}}>1$. In modern orogens, $\mathrm{Nb}$ enriched basalt occurs in arcs, rifted arcs, and back arc settings. 
Basalts
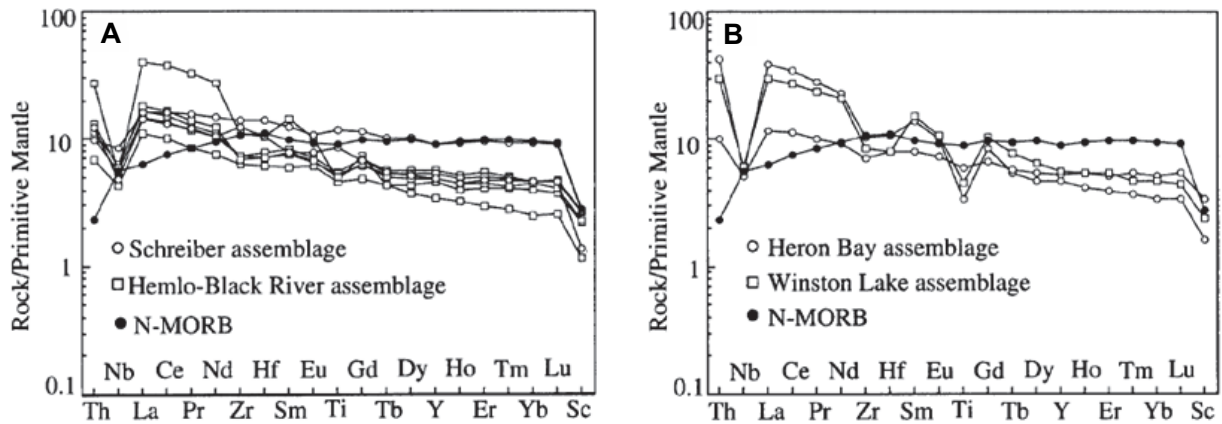

Andesites
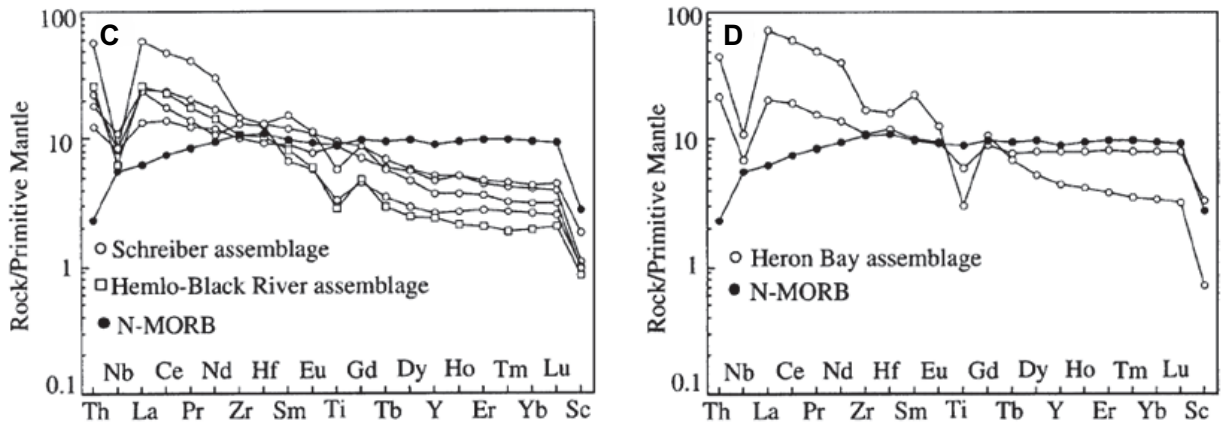

Magnesian andesites
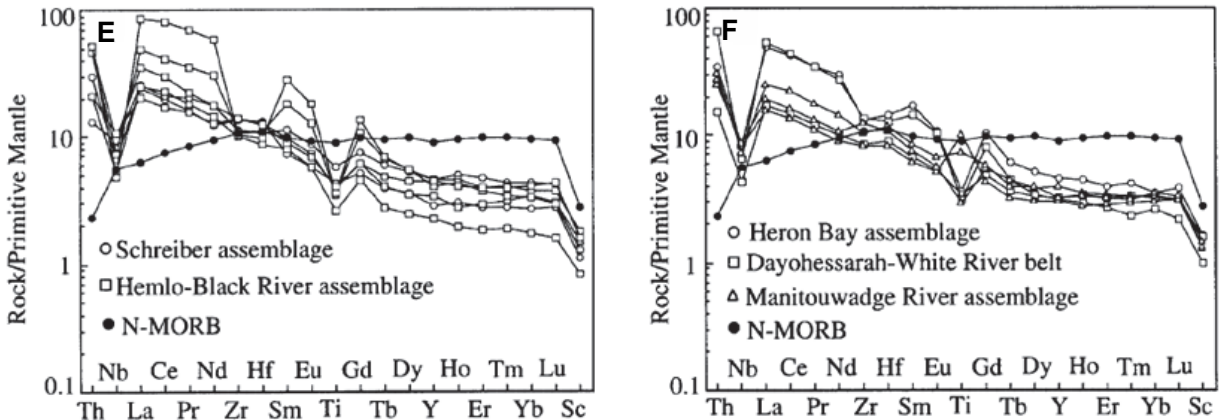

Figure 14. Extended trace element plots of basalts, andesites and magnesian andesites from greenstone belts of the Wawa-Abitibi terrane west of the Kapuskasing structural zone (Polat and Kerrich 2001). Normalizing factors from Hofmann (1988).

The trace element characteristics are similar to those of ocean island basalts (OIB) and have been attributed either to an asthenospheric or lithospheric component in their sources, or to small degrees of melting of a mid-ocean-ridge basalt (MORB) source in a slab window (D'Orazio et al. 2000). Nbenriched basalts have also been attributed to adakitic metasomatism above a mantle wedge (Sajona et al. 1996). Nbenriched basalts occur in the western Wabigoon subprovince of the Superior craton (Wyman et al. 2000), the south margin and elsewhere in the North Caribou terrane (Hollings and Kerrich 2000, 2002; Fig. 15), and the Pilbara (Smithies et al. 2005), Dharwar (Kerrich and Manikyamba 2012) and Karelian (Svetov et al. 2004) cratons. No stratigraphic or volcanological context is provided in the above studies except for the work of Svetov et al. (2004).

\section{Felsic Volcanic Units}

Felsic rocks of the bimodal association in Archean greenstone belts range from dacite to rhyolite and so-called high-silica rhyolite. Thurston (1981) noted that these rocks vary enormously in their trace element character. Subsequent work by Lesher et al. (1986) resulted in a classification based on their trace element chemistry, later modified by Hart et al. (2004). The felsic volcanic rocks are classified by $\mathrm{Zr} / \mathrm{Y}$, as shown in Table 3. The common feature of the petrogenetic schemes in Table 3 is that they involve fractional crystallization or melting of a tholeiitic basaltic precursor. Felsic volcanic units also occur in the komatiite-tholeiite association, the rhyolites associated with the Kidd Creek VMS deposit being the most prominent example (Bleeker 1999).

\section{Successor Basins}

After early deformation of greenstone belts, successor basins developed unconformably above the volcanic rocks. The basal unconformities are generally paleosols (Ayer et al. 1999), indicating that the greenstone belts were at least briefly subaerial. The basins occur in proximity to major transcurrent faults in the greenstone belts and, although relatively late, the basins preserve the same metamorphic grade as the surrounding greenstones. The successor basins are only a few $\mathrm{km}$ in width but extend several tens of $\mathrm{km}$ along strike. They are the remnants of originally much more extensive basins, as outliers are found tens of $\mathrm{km}$ away from the main preserved basins (Thomson 1946).

\section{Successor Basin Sedimentary Units}

Two periods of deposition of Archean successor basin metasedimentary rocks are recorded in the Abitibi greenstone belt: early sand-grade clastic units in the western Wawa-Abitibi terrane (the so-called Porcupine metasediments), followed by later conglomerates displaying gravel lags and intercalated cross-bedded sands (the so-called Timiskaming metasediments). Together, these rocks are diagnostic of alluvial-fluvial environments (Dimroth et al. 1982; Thurston and Chivers 1990; Mueller and Corcoran 1998) that grade laterally to deep marine sands (Dimroth et al. 1982). These units unconformably overlie the older volcanic rocks and occur along major transcurrent shear zones within greenstone belts, suggesting that the basins are, at least in part, faultcontrolled. The early sand-grade units (Porcupine type) are more laterally extensive than the later, coarser Timiskaming type units. The presence of foliated and massive granitoid clasts in the conglomerates (e.g. Mueller and Corcoran 1998) indicates that early deformation preceding the development of the successor basins included emplacement and unroofing of 


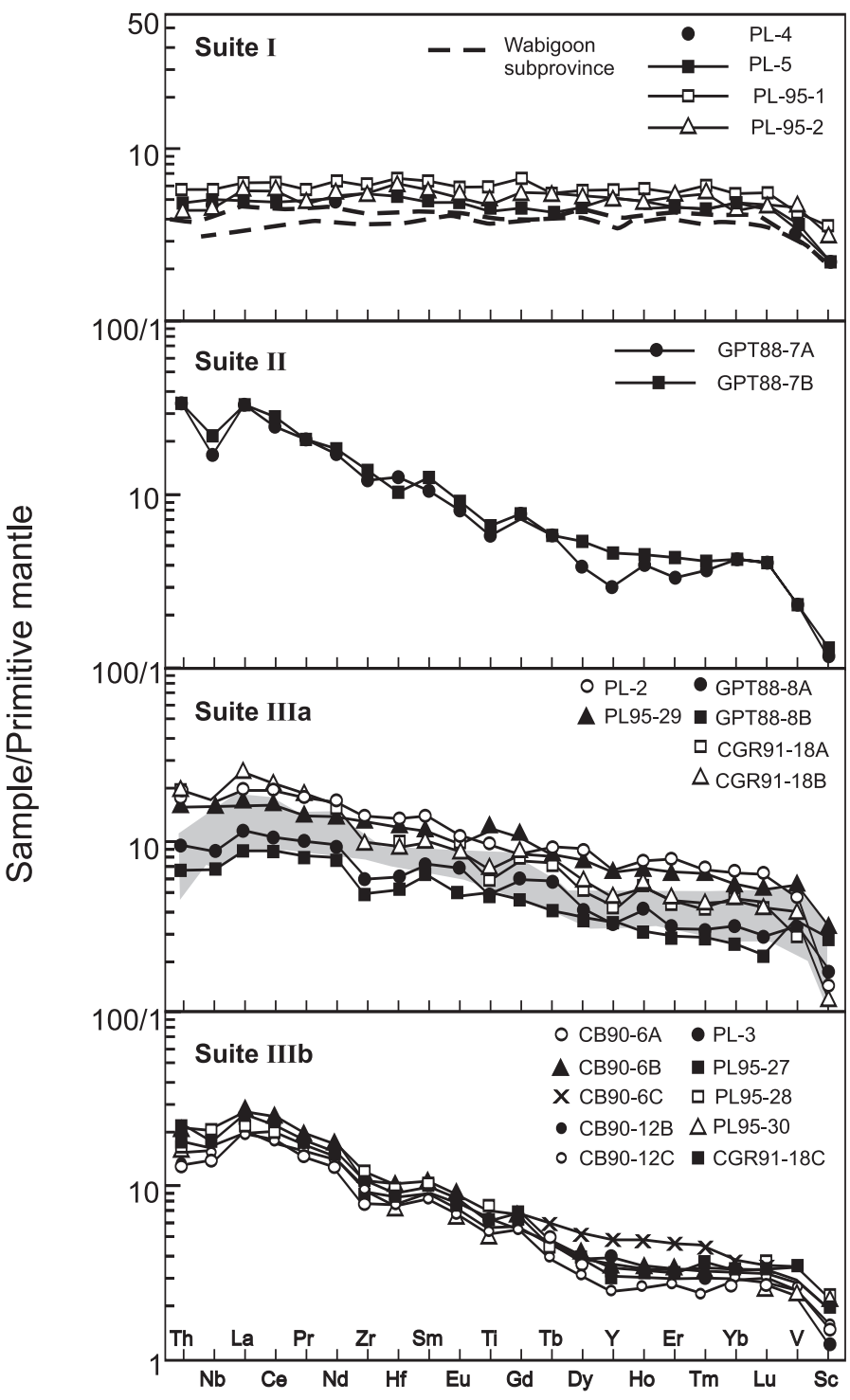

Figure 15. Primitive mantle normalized extended trace element plots for $\mathrm{Nb}$ enriched basalts of the Northern Pickle Assemblage rocks (after Hollings 2002). Wabigoon subprovince data are unpublished data from D. Wyman. The grey field is Niobium-enriched basalts from the Sturgeon Lake greenstone belt in the western Wabigoon terrane (Wyman et al. 2000). Normalizing values from Sun and McDonough (1989). Suite I is unfractionated tholeiites, Suite II is fractionated tholeiites, Suite IIIa is high Fe tholeiites which are more fractionated than Suite IIIb.

granitoid batholiths. Iron-formation clasts in the type Timiskaming of the Kirkland Lake area in the Abitibi greenstone belt suggest a widespread pelagic sedimentation event that terminated Keewatin deposition in that region and elsewhere. Similar units are found in the Slave (Bleeker and Hall 2007), Zimbabwe (Martin et al. 1993), Pilbara (Van Kranendonk et al. 2002), Yilgarn (Krapez and Barley 1987); and Baltic (Slabunov et al. 2006) cratons. Development of the basins is discussed in a subsequent section.

\section{Successor Basin Volcanic Units}

Magma emplaced during successor basin development generally range from calc-alkaline to alkaline in composition; one instance of komatiitic volcanism is associated with the Porcupine unit in the Abitibi greenstone belt (Wray 2014). The alkaline volcanic rocks are generally shoshonitic $\left(\mathrm{K}_{2} \mathrm{O} / \mathrm{Na}_{2} \mathrm{O}>1\right)$, hornblende-phyric andesite and more siliceous derivatives (Shegelski 1980; Brown 1995). An example of the calc-alkaline type is the Shebandowan assemblage in the Wawa-Abitibi terrane just west of Thunder Bay (No. 1 in Fig. 1). Rocks of this assemblage are characterized by LREE abundances about 100 times that of chondrites (Brown 1995), and are spatially associated with more fractionated types (Carter 1993). In the Wawa-Abitibi terrane, the proximal successor basin volcanic rocks of the type Timiskaming have shoshonitic geochemistry, and alkalic dikes and plutons are proximal to major strike-slip structures (Wyman and Kerrich 1989; Othman et al. 1990; Dostal and Mueller 1992). In the northern reaches of the Superior Province, shoshonitic volcanic rocks occur in the North Caribou terrane at Oxford Lake (Brooks et al. 1982) and at North Spirit Lake (Smith and Longstaffe 1974). In the Wabigoon subprovince, alkalic volcanic rocks occur in the Lake of the Woods area (Dostal et al. 2004). Late stage alkalic magmatism also occurs in the western Dharwar (Manikyamba et al. 2012), the Yilgarn (Taylor et al. 1990), and Pilbara (Krapez and Barley 1987) cratons, the Shamvaian sequence in the Zimbabwe craton (Blenkinsop et al. 1997) and in the Baltic shield (Slabunov et al. 2006). In general, the successor basins occur at the margins of terranes or proximal to major structures such as the Porcupine-Destor shear zone in the Abitibi greenstone belt. The extremely fractionated REE patterns of the shoshonitic units suggests that they represent direct mantle melts involving low percentages of partial melting (Othman et al. 1990).

\section{Sedimentary Subprovince Volcanic Units}

The volcanic rocks of greenstone belts are overlain by wackepelite turbidites of adjacent metasedimentary subprovinces. For example, North Caribou terrane greenstones are overlain by wacke-pelite units of the English River subprovince (Breaks 1991; Stott and Corfu 1991). Volcanic rocks form a minor component of the sedimentary subprovinces; the Piché Group within the Pontiac metasedimentary subprovince (Simard et al. 2013) immediately south of the Abitibi greenstone belt is the best known example. These volcanic units are thin, but have a lateral extent of tens to hundreds of kilometres. They vary from komatiite through tholeiitic basalt and calc-alkaline basalt to rhyolite (Stone 1990; Simard et al. 2013). Similar minor metavolcanic rocks form unnamed metavolcanic units in the English River subprovince (Breaks 1991) and the Quetico subprovince (Williams 1991); however, there are limited geochemical data.

\section{SEDIMENTARY UNITS IN GREENSTONE BELTS}

\section{Introduction}

Archean greenstone belts typically have $<10 \%$ sedimentary rocks in the pre-deformation mafic-to-felsic volcanic cycles. Four types of sedimentary sequences are recognized, as summarized by Bédard et al. (2013): 1) subaerial to shallow-water clastic sequences rich in continental detritus; 2) continental rupture sequences containing shallow-water quartz-rich sedimentary and carbonate rocks, succeeded by BIF and deeperwater komatiite-tholeiite units; 3) deep-water chemical sedimentary units (the 'sedimentary interface zones' of Thurston et al. 2008); and 4) clastic and chemical sequences fringing or 


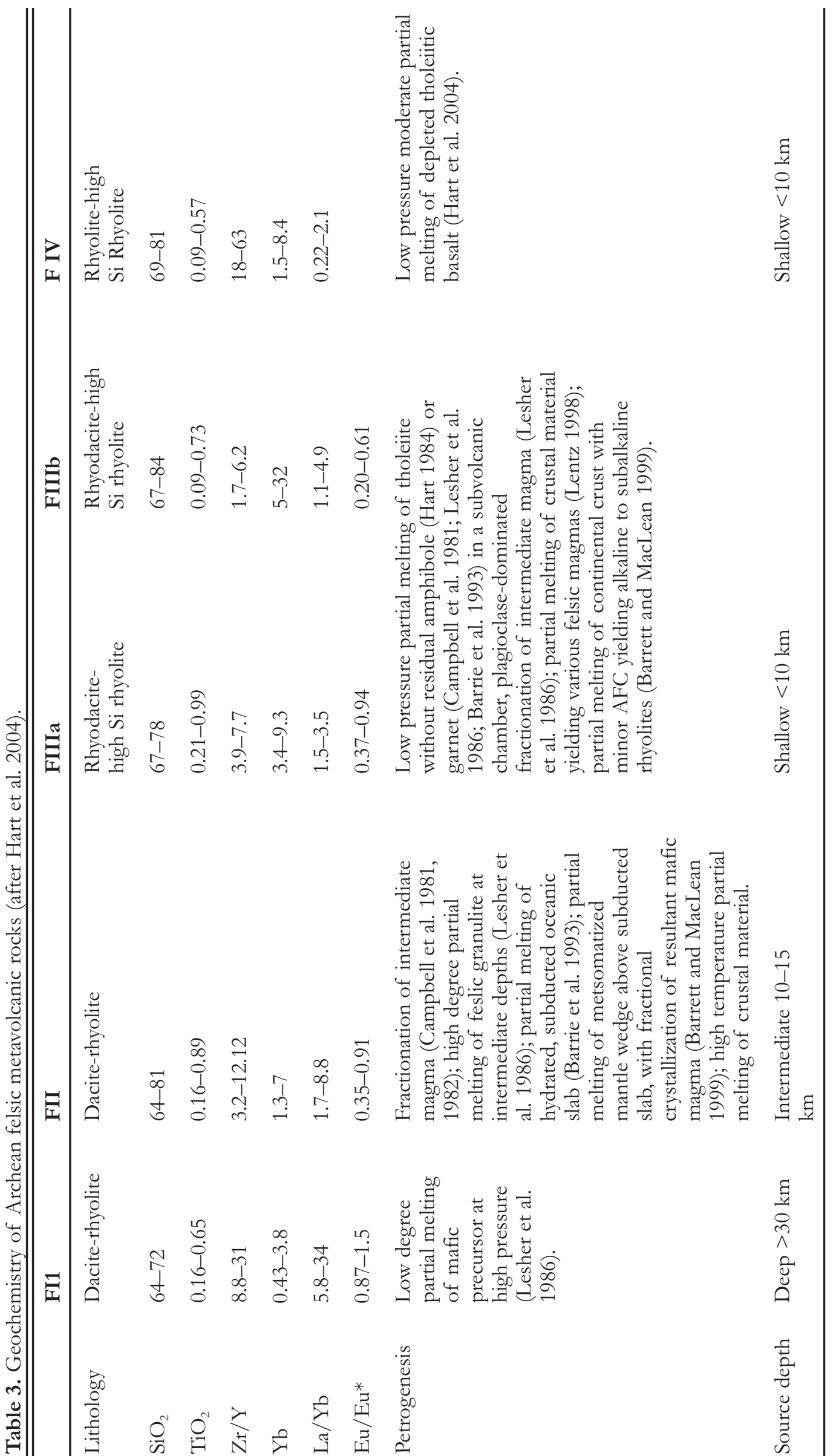

capping older cratonic blocks. The syn-orogenic flysch deposits and Timiskaming metasedimentary units are described elsewhere in this contribution.

\section{Continentally-Derived Clastic Rocks}

Some of the greenstones deposited on or above the margins of older cratonic blocks (Kamber et al. 2004; Fralick et al. 2008) represent fluvial-deltaic environments dominated by coarse clastic rocks of TTG provenance. Subsequent basin subsidence and transgression led to basin starvation and deposition of carbonates, chert and BIF. This style of deposition is present in the 3.0-2.8 Ga Marmion Terrane of northwestern Ontario (Buse et al. 2010) and in the Zimbabwe craton, where shallow-water, quartz-rich metasedimentary rocks are succeeded by argillite and sulphidefacies iron-formation (Prendergast 2004).

\section{Continental Rupture \\ Sequences}

These sequences of quartz-rich metasedimentary rocks are deposited unconformably above older greenstone and granitoid rocks in most cratons, including the Superior (Donaldson and de Kemp 1998), Slave (Mueller and Pickett 2005; Bleeker and Hall 2007), Zimbabwe (Prendergast 2004), and Yilgarn (Myers and Swager 1997) cratons. In some cases, these sequences mark the base of greenstone belts, whereas elsewhere (e.g. Ponask Lake in the North Caribou terrane; Thurston et al. 1991) they mark the edges of cratonic blocks. The quartz-rich metasedimentary units are underlain by paleosols (Breaks 1991) and contain shallow-water structures such as hummocky cross-stratification and mud drapes, followed in turn by stromatolitic carbonates and siliciclastic rocks (Arias et al. 1986), a deepening basin sequence of shale and BIF, and upon basin rifting, emplacement 
of komatiite-tholeiite sequences. Although similar to sequences within Atlantic-style passive margins, the lateral distance from the tidal environment to submarine fan structures is commonly only $5-8 \mathrm{~km}$ (Goutier et al. 1999), much less than an Atlantic-style margin.

\section{Sedimentary Interface Zones}

'Sedimentary Interface Zones' (Thurston et al. 2008) are zones of chemical and lesser clastic sedimentary rocks capping mafic to felsic volcanic cycles in greenstone belts worldwide. These zones are accumulations of chemical metasedimentary rocks and minor clastic material from a few $\mathrm{cm}$ to $\sim 500 \mathrm{~m}$ thick. Their stratigraphic association with volcanic rocks, petrography, geochemistry and isotopic composition indicates that these units are dominated by Algoma-type BIF (Thurston et al. 2008; Baldwin 2009) deposited below storm wave base by one or more of the following processes: 1) direct precipitation from seawater; 2) deposition from hydrothermal fluids; or 3) replacement of precursor rock types.

$\mathrm{U}-\mathrm{Pb}$ zircon geochronology of rhyolites at the top of the ca. $2734 \mathrm{Ma}$ Deloro assemblage in the Abitibi greenstone belt and in the immediately overlying $2710 \mathrm{Ma}$ sequence show a locally developed ca. 25 m.y. age gap. The fundamental question stemming from these apparent age gaps between dated rhyolites in neighbouring assemblages is whether they represent slow, continued volcanic evolution, or lengthy deposition of the chemical sedimentary rocks separating mafic to felsic cycles. Thurston et al. (2008) modelled accumulation of the $750,000 \mathrm{~km}^{3}$ of volcanic rocks in the Deloro assemblage south of Timmins (Abitibi greenstone belt) over periods ranging from 7.5 k.y. to 5 m.y., using rates of magma accumulation for chemically-zoned ash flow magma chambers, plume systems, and modern arc systems, all representing minimal accumulation rates given a hotter Archean Earth. These rapid rates of volcanism compared to the time gaps between assemblages in the western part of the Abitibi greenstone belt suggest that chemical sedimentary units marking magma clan transitions represent periods of slow deposition. These estimates of depositional rates were corroborated by $\mathrm{U}-\mathrm{Pb}$ dating of bounding rhyolite units (Baldwin 2009), which indicate that the rate of deposition was fairly slow, i.e. $0.060-0.008 \mathrm{~mm} / \mathrm{y}$ (Baldwin 2009) for a $40 \mathrm{~m}$-thick BIF, perhaps comparable to sedimentation rates in the mid-Pacific Ocean (Gleason et al. 2004). Thus, apparently minor chemical and associated clastic sedimentary units, including minor $\mathrm{cm}$-scale graphitic argillites marking magma clan transitions, are important in assessing the rate of accumulation and volcanic evolution in greenstone belts. However, it should be noted that the 'key tuffite,' a chert and/or fine-grained felsic ash marker horizon 2734-2724 Ma at Matagami, is bounded above and below by rhyolite having ages that overlap within error (Ross et al. 2014).

\section{Continental Margin Sedimentation}

The margins of Archean microcontinental fragments in the Superior and Yilgarn cratons are the sites of off-lapping, mixed clastic and chemical metasedimentary units. The Superior Province example is composed of a $2.85-2.75 \mathrm{Ga}$, southwest-younging sequence of wackes, siltstones and iron-formation along the south margin of the 3.4-2.8 Ga Winnipeg River subprovince, where it is juxtaposed against $2.75-2.72$ Ga juve- nile volcanic rocks of the western Wabigoon subprovince (Sanborn-Barrie and Skulski 2006). Some microcontinental terranes in the Superior Province (Fralick and Pufahl 2006) and the Yilgarn craton (Angerer et al. 2010) have unconformably overlying shallow-water iron-formation.

\section{Archean Sedimentary Patterns}

Basement-cover relationships of older vs. younger greenstones (Blenkinsop et al. 1993; Buick et al. 1995; Bleeker 2003), abundant compositionally mature sedimentary units (Krapez and Barley 1987; Hessler and Lowe 2006), isotopic and trace element evidence (Kamber 2010), and generally coarse-grained epiclastic units associated with greenstone mafic to felsic cycles (Mueller and Corcoran 1998; Corcoran and Mueller 2007), all point to the presence of exposed continents and subaerial weathering. This evidence is also supported by isotopic considerations (Dhuime et al. 2012). The sand-rich nature of Archean sedimentary rocks points to a depositional system in which the sediment source is proximal and characterized by high relief and a narrow shelf, whereas mud-rich systems (seen mainly in sedimentary subprovinces of the Superior Province), reflect a sediment source distant from the shoreline in a low relief environment (Bouma 2000).

The quartz-rich nature of Meso- and Neoarchean metasedimentary rocks is a function of a largely granitoid source and intense chemical weathering under reducing conditions. The paucity of clays and feldspars, and enrichment of Archean mudstones in $\mathrm{Al}$ relative to younger mudstones (Eriksson and Soegaard 1985; Hessler and Lowe 2006) reflect this style of weathering. The erosion of Archean volcanic rocks brought about similar Al enrichment in Archean metasedimentary rocks relative to younger equivalents, whereas sedimentary units display a steady decrease in $\mathrm{Mg}$ content over time (Migdisov et al. 2003). Enrichment in $\mathrm{Al}$ is a function of a largely granodioritic source and extensive weathering, and the decrease in $\mathrm{Mg}$ is a function of the overall decrease in komatiite eruptions over time (Arndt et al. 2008; Van Kranendonk 2012).

Archean sedimentary carbonate units are scarce (Ojakangas 1985), and where present, commonly occur at the top of mafic to felsic volcanic cycles in sedimentary interface zones (Thurston et al. 2008). These carbonate rocks are shallowwater rocks featuring multiple forms of stromatolites (Hofmann et al. 1985; Arias et al. 1986; Wilks and Nisbet 1988; Hofmann et al. 1991; Hofmann and Masson 1994).

There is little evidence constraining the depth of water in greenstone belt metasedimentary units, except, for example, quartzose sedimentary rocks of the continental rupture sequences that display hummocky cross-stratification and mud drapes typical of the tidal environment (Donaldson and de Kemp 1998). Estimates of mean ocean depth in the Archean are $\sim 2.6 \mathrm{~km}$ (Bickle et al. 1994). With this mean depth in mind, one might conclude that greenstone belts represent deep-water deposits; however, the near total absence of mudstones, which typically form $70 \%$ of Phanerozoic abyssal sedimentary sequences (Aplin and Macquaker 2011) suggests that greenstone belts either do not represent a deep-water environment, or that Archean oceans were remarkably free of fine-grained detritus. 


\section{CONTROLS ON VOLCANIC CYCLICITY}

\section{Introduction}

Many of the geochemical studies referred to in the preceding sections provide limited stratigraphic detail beyond the level of major geochemical groupings and the relationship of the geochemistry to broad stratigraphic groups. However, in the minority of studies that utilized detailed stratigraphy as a control on geochemical variation, insight into magma chamber dynamics can be obtained.

\section{Fe-Enrichment Cycles: Evidence for Fractionation}

Tholeiitic basaltic sequences within the komatiite-tholeiite association (e.g. the western Abitibi greenstone belt; Jensen 1985) and the bimodal basalt-dacite association (e.g. the Confederation assemblage on the south margin of the North Caribou terrane; Thurston and Fryer 1983) show Fe-enrichment cycles ranging from $6-8 \%$ to $18-20 \% \mathrm{FeO}^{*}$. Similar Feenrichment cycles are observed in the Fe-rich tholeiites of northern Québec (Maurice et al. 2009) and in many tholeiitic sequences throughout the Superior Province (Ludden et al. 1986), the Pilbara craton (Van Kranendonk et al. 2002), the Yilgarn craton (Barley 1997) and the Slave Province (Bleeker and Hall 2007). The high-Fe tholeiites are occasionally capped by variolitic flows (Gélinas et al. 1976; Thurston and Fryer 1983), with or without minor sedimentary rocks. Fe-enrichment cycles in tholeiitic basalts are interpreted to represent an initial mantle-derived tholeiitic liquid evolving by fractionation of olivine and plagioclase in a low pressure magma chamber, in rare cases to the point of developing liquid immiscibility (Gélinas et al. 1976; Thurston and Fryer 1983).

\section{Fractionation vs. Mantle Input}

In the Chibougamau area of the Abitibi greenstone belt, Leclerc et al. (2011) divided the ca. 2730 Ma Roy Group into multiple units (Fig. 16) of largely tholeiitic and minor calc-alkaline units. Insight comes from examination of the stratigraphically controlled geochemistry of the David Member of the Obatogamau Formation. The authors report that the basalts and basaltic andesites of this member show no chemical variability with stratigraphic position in spite of their relatively evolved compositions (about $5 \% \mathrm{MgO}$ ). This lack of variation is explained in terms of fractionation being balanced by input of fresh mantle-derived magma. An upward decrease in $\mathrm{Zr} / \mathrm{Y}$, $\mathrm{P}_{2} \mathrm{O}_{5}$ and $\mathrm{TiO}_{2}$ at near constant $\mathrm{MgO}$ are explained as sampling of increasingly depleted starting material by successive magma batches. The authors further speculate as to whether this represents exhaustion of fertile components in the mantle, changes in the mantle source, or a progressive increase in the degree of partial melting.

Overlying the David Member, felsic units of the Allard and the Queylus members are calc-alkaline. Their fractionated REE patterns reflect a garnet-bearing residue, suggesting that a metabasite source was melting at high pressure. Transitional to calc-alkaline mafic rocks are interpreted as mixtures of minor volumes of these melts with variable proportions of background tholeiites, which are interfingered with the felsic units. However, in the upper part of the Allard Member, tholeiites are absent, implying that the crust acted as a density filter (Hildreth 1981; Thurston and Sutcliffe 1986), preventing eruption of the tholeiites.

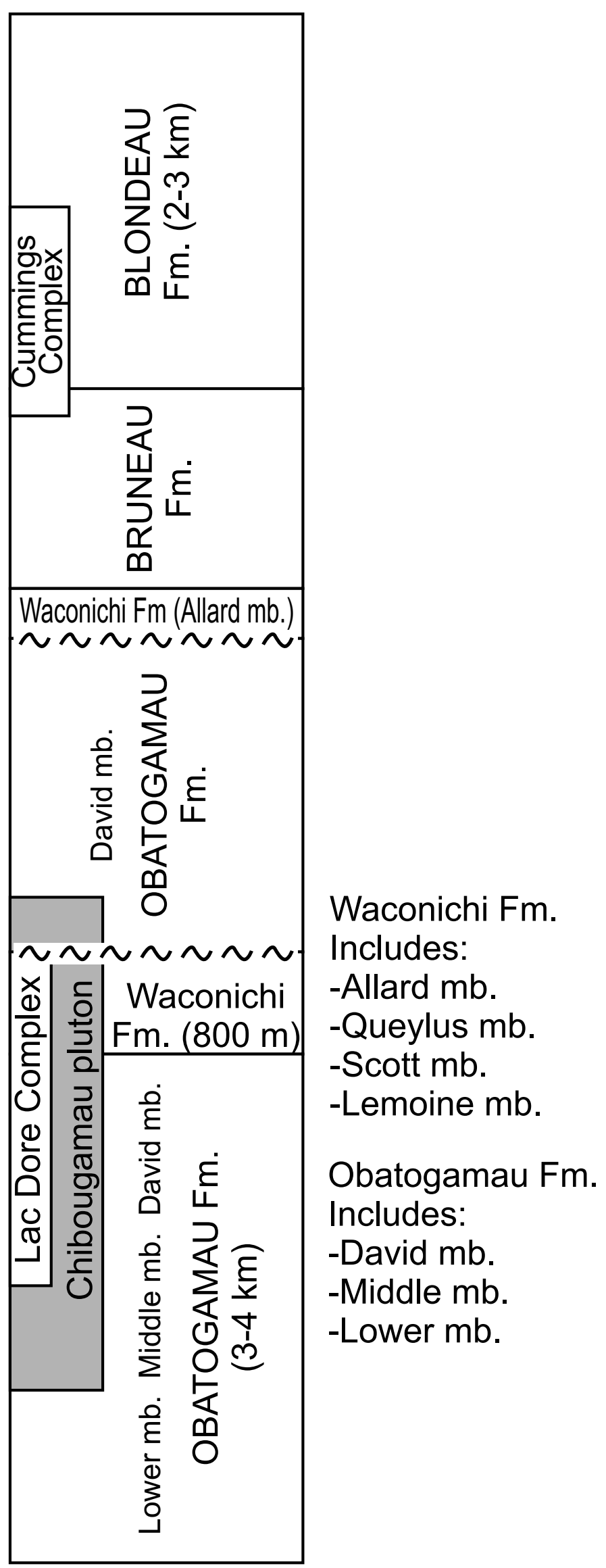

Figure 16. Stratigraphic nomenclature for the Chibougamau greenstone belt (after Leclerc et al. 2011). 


\section{Origin of Felsic Volcanic Rocks by Contamination - or Two Separate Sources?}

Felsic metavolcanic rocks are a minor constituent of greenstone belts and their petrogenesis is largely independent of basalt petrogenesis. A full fractionation sequence from basalt to andesite and rhyolite is reported in the Marda complex of the Yilgarn craton (Taylor and Hallberg 1977); however, Thurston and Fryer (1983) demonstrated that fractionation of a basaltic sequence in the North Caribou terrane could not produce the volume of rhyolite capping the $2.74 \mathrm{Ga}$ Confederation assemblage east of Red Lake (No. 2 on Fig. 1). In fact, many basaltic sequences are capped by sedimentary interface zones (Thurston et al. 2008), indicating the cessation of volcanism. In the Abitibi greenstone belt (Leclerc et al. 2011), the calc-alkaline Allard Member is a 500 m-thick package of andesite to dacite/rhyodacite within a thick sequence of tholeiites. Several authors (Barrie et al. 1993; Hart et al. 2004; Leclerc et al. 2011) envision that basalts represent one end member and rhyodacites produced by anatexis (crustal melting) form the other end member. Modelling indicates that intermediate units represent mixing of varying proportions of basalt and anatectic rhyodacite in the magma conduit (Leclerc et al. 2011; J. Bédard personal communication; Fig. 17).

\section{Archean Andesites}

Phanerozoic andesites are plagioclase- and pyroxene-phyric intermediate volcanic rocks found in continental and island arcs, and more rarely in oceanic islands, oceanic plateaus, Large Igneous Provinces and back-arc settings (Hooper et al. 2002; Scarrow et al. 2009; Willbold et al. 2009). The origin of these andesites is mainly by mixing of mafic and felsic magmas regardless of geodynamic setting (Reubi and Blundy 2009). However, icelandites (low-Al, high-Fe andesites, a relatively rare rock type; Carmichael 1964) form by fractionation (Sensarma and Palme 2013). Andesites in Phanerozoic continental arcs are mainly produced by mixing of mantle-derived basalt with melted continental crust (Gill 1981; Tatsumi 2005). As andesites can constitute up to $35-40 \%$ of continental arcs and represent about $30 \%$ of rock types in island arcs, based on a compilation by Winter (2001; p. 326) of 397 Andean and 1484 southwest Pacific analyses from Ewart (1982), they can be considered a hallmark of plate tectonics. Modern andesites possess negative $\mathrm{Ti}, \mathrm{Nb}$ and $\mathrm{Ta}$ anomalies, which have been related to the presence of residual Nb- and Ta-bearing minerals such as rutile, ilmenite, titanite, and perhaps hornblende (Morris and Hart 1983; Saunders et al. 1991). Others argue for enrichment of the adjacent elements on extended trace element diagrams, and suggest that the HFSE are similar in abundance to MORB and reflect source characteristics (McCulloch and Gamble 1991). However, Jahn (1994) calculated that contamination of primitive mantle by $\sim 2 \%$ upper crustal material would produce negative $\mathrm{Nb}$ and Ta anomalies. Bédard (2006), using partition coefficient data, states that $2 \%$ rutile in the source would have a similar effect.

Archean andesites are rare (Condie 1981; Ayres and Thurston 1985) and generally lack the plagioclase and pyroxene phenocrysts typical of Phanerozoic andesites. Proposed origins for Archean andesites include extensive fractionation of large basaltic magma chambers accompanied by some admixing of felsic melts (Smithies et al. 2007), as well as sim-

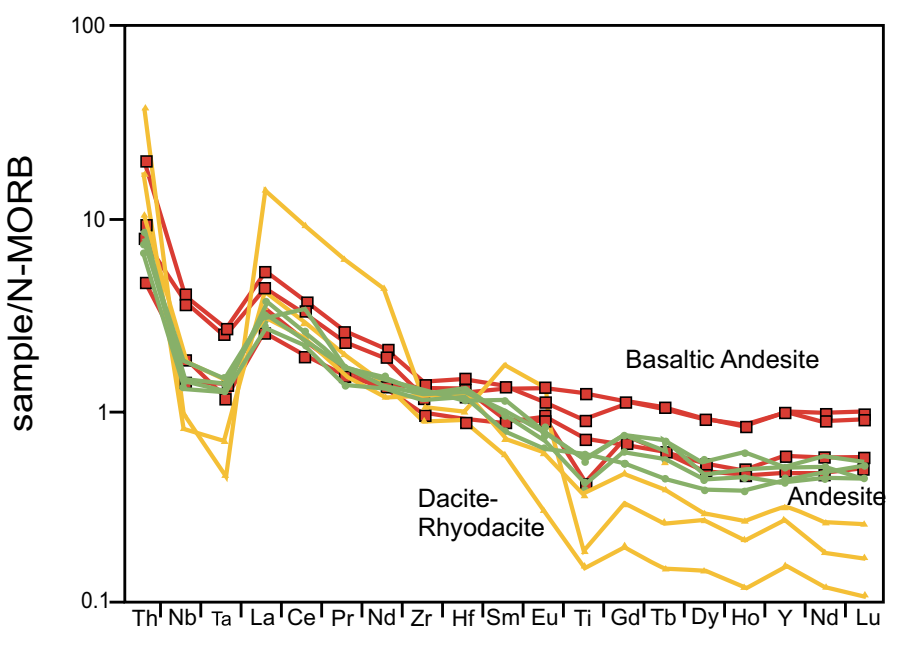

Figure 17. MORB-normalized analyses of basaltic andesite to rhyodacite in the Chibougamau greenstone belt of the Abitibi-Wawa terrane (after Bédard et al. 2013). MORB normalizing factors after Sun and McDonough (1989).

pler mixing scenarios (Bédard et al. 2013). In the Yilgarn craton, Barnes and Van Kranendonk (2014) provided convincing field evidence and modelling to conclude that Archean andesites in the Yilgarn are a product of plume-related tholeiites mixed with rocks having TTG compositions. Thurston and Fryer (1983) postulated two possible additional origins for Archean andesites: 1) primary andesitic melts; and 2) fractionation of basaltic precursors.

\section{STRUCTURAL GEOLOGY OF GRANITE-GREENSTONE TERRANES}

\section{Introduction}

The structural style of greenstones plays a pivotal role in constraining geodynamic models for greenstone belt development (Anhaeusser 2014). The two major points of view are that tectonic processes were dominated by either gravitational tectonics or compressional forces. The so-called 'granite-greenstone pattern' (Macgregor 1951) consists of upward-younging and upward-facing volcanic stratigraphy, surrounded by granitoid rocks.

\section{Structural Style}

The predominant structural style of Archean granite-greenstone terranes is a series of alternating high-amplitude (minimum $15 \mathrm{~km}$ ), long-wavelength (ca. $20 \mathrm{~km}$ ) domes of TTG and keels of volcanic rocks - a style unique in Earth history (Fig. 2). This structural style is broadly similar world-wide, whether an older granitoid basement is identified, such as in the Pilbara craton (Van Kranendonk et al. 2002, 2004) or if identification of basement is elusive, such as in most Superior Province greenstone belts (Williams et al. 1992; Thurston et al. 2008). The best understood example, by virtue of extensive mapping and geochronology of both granitoid rocks and supracrustal rocks, is the eastern Pilbara terrane (Fig. 18), where tightly folded synclines of volcanic rocks alternate with broad domes of TTG batholiths (Van Kranendonk et al. 2004). Wrapping of supracrustal rocks around the granitoid domes is a function of upward movement of the domes, i.e. diapiric emplacement of the granitoid rocks - a pattern also seen in the Abitibi green- 


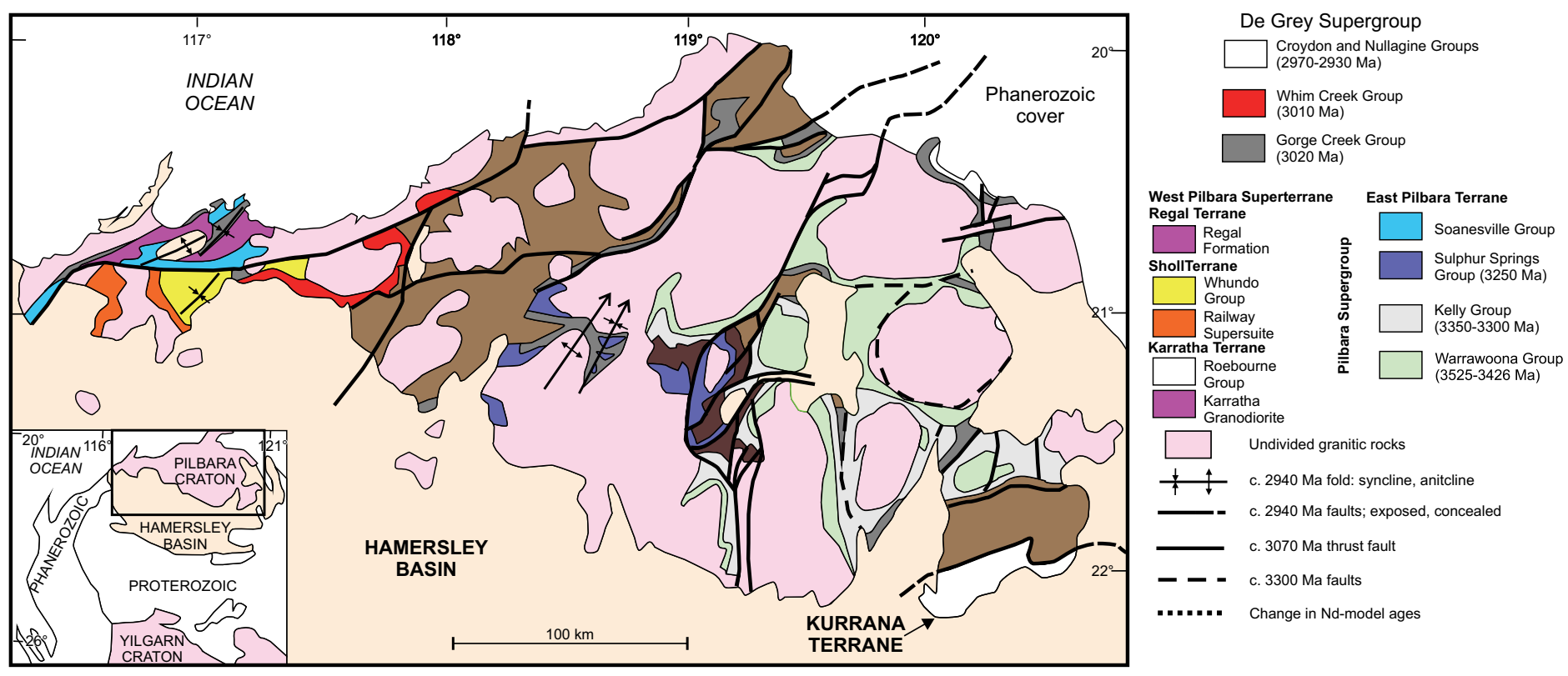

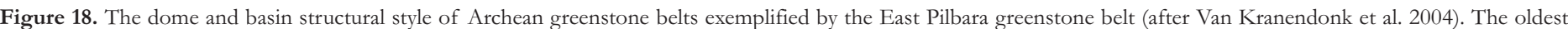

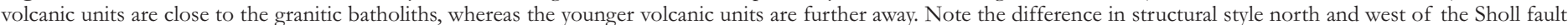

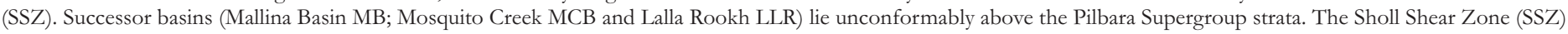

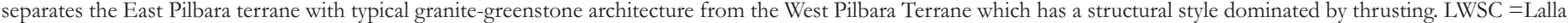
Rookh-Western Shaw structural corridor.

stones (Heather 2001). The granitoid units of the domes display an inward-younging pattern (Van Kranendonk et al. 2002, 2004), unlike classical diapirs. The ubiquity of isotopic inheritance in Archean batholiths implies ensialic magmatism, i.e. magmatism within a granitic, continental environment (Larbi et al. 1999; Davis et al. 2000; Smithies et al. 2007).

The emplacement of granitoid bodies by diapirism is a key piece of evidence for vertical tectonics in granite-greenstone terranes. Examples of diapiric granitoid rocks occur in the East Pilbara terrane (Van Kranendonk et al. 2004), the Barberton greenstone belt in the Kaapvaal craton (Anhaeusser 1984), the Zimbabwe craton (Jelsma et al. 1993), the Yilgarn craton (Bloem et al. 1997), the Yellowknife greenstone belt in the Slave craton (Drury 1977), and the Wabigoon subprovince of the Superior Province (Schwerdtner 1984). Granitoid domes surrounded by greenstones occur throughout the Superior Province (Williams et al. 1992), but most examples lack the detailed structural studies necessary to postulate diapiric emplacement.

Worldwide, the stratigraphy of Archean greenstone belts is characterized by upward structural facing and upward younging, except where dismembered by subsequent deformation. Examples having good stratigraphic and geochronologic control include the Superior craton (Stott and Corfu 1991; Thurston et al. 2008) and the Pilbara craton (Van Kranendonk et al. 2002). Stratigraphic units decrease in age with increasing distance from the batholiths, suggesting that these batholithcentered zones are mid- to upper-crustal sections (Thurston et al. 2008).

An elegant explanation of this dome-and-keel structural style is provided by the 'punctuated partial convective overturn' model of Van Kranendonk et al. (2004). This model consists of granitoid basement overlain by higher density greenstone belt basalt. TTG sills were emplaced into the base of the greenstone succession and also fed felsic eruptive centres in the overlying basalts, creating an uneven distribution of denser basalts $v$ s. less dense TTGs and coeval volcanic units. In the second stage, a younger, extensive and thick basaltic sequence was deposited on the older units. Meanwhile, the elevated content of radiogenic heat-producing elements ( $\mathrm{U}, \mathrm{Th}$, and $\mathrm{K}$ ) in the underlying granitoid rocks rendered the latter somewhat plastic. The overall gravitational instability of dense basaltic material overlying softened granitic material led to sagging of the basaltic domain, forming keels between up-rising, less dense, dome-forming granitoid rocks.

Some greenstone belts display a long, linear form, such as the Yilgarn craton (Gee et al. 1981; Swager et al. 1990). At the scale of terranes, the Superior Province consists of long, linear granite- greenstone terranes, but the greenstone belts within these terranes in the northern part of the Superior Province commonly display dome-and-keel structural style (Stott and Corfu 1991; Thurston et al. 1991). The dome-and-keel structural style in the eastern Pilbara is bordered to the north and west by the West Pilbara granite-greenstone terrane. The latter greenstones are somewhat younger than those in the classic East Pilbara stratigraphic section, but the important distinction between the two is the northeasterly structural grain of the West Pilbara and the fact that granitoid rocks are structurally simpler than in the East Pilbara, and discordant to the supracrustal units. Thus, Van Kranendonk et al. (2002) invoke an early episode of vertical tectonics followed by later horizontal tectonics, including major, terrane-bounding shear zones and thrust-based stratigraphic transport and duplication.

\section{Successor Basin Structural Style and Genesis}

The dome-and-keel structural style described above must be modified to accommodate the presence of scattered successor basins having the following characteristics: 1) metamorphic 
grades similar to the surrounding greenstones; 2) rapid transition from fluvial to deep-water facies; and 3) the presence of mantle-derived alkaline magmatism. Bleeker (2012) has synthesized a model for the late structural evolution of greenstone belts (concentrating on the western part of the Abitibi greenstone belt) and the place of orogenic gold deposits in that process, as follows (Fig. 19): 1) early folding, thrusting and terrane imbrication (Bleeker and Van Breemen 2011); 2) synorogenic extension; 3) later thick-skinned extension that inverted earlier extensional structures; 4) further shortening and steepening of structures; and 5) transpression and associated sinistral and later dextral strike-slip movement.

Early folding was involved in the development of the above-noted dome-and-keel structures, and was followed by local-scale thrusting (e.g. the out-of-sequence position of the Kidd-Munro assemblage north of the Porcupine-Destor structure). In the Timmins area, a second phase of folding has produced the so-called 'Porcupine syncline,' which is cut by the unconformity at the base of the Timiskaming rocks. Subsequent synorogenic extension is marked by uplift and erosion, filling the successor basins. Extension is required to explain the alkaline to calc-alkaline magmatism and the presence in the conglomerates of foliated granitoid clasts, indicative of uplift and exhumation of mid-crust. The rapid lateral transition within these basins from alluvial-fluvial facies to deep-water wackes is explicable by extension and strike-slip processes. The 'major breaks' or transcurrent faults in greenstone belts are not numerous and have a spacing perpendicular to strike of several tens of $\mathrm{km}$. These 'major breaks' are late, and transect early thrusts, but are spatially associated with the successor basins. Given the close spatial relationship of the 'breaks' and the basins, Bleeker (2012) proposed that the 'breaks' are first-order extensional structures. The common development of extensional shear bands in granitoid plutons at greenstone belt margins (Beakhouse 2013) is consistent with extensional processes. The extent of these extensional detachments is shown in Figure 20 for an area in the western Superior Province. It should be noted that some of the faults near the interface between the Wabigoon subprovince and the older Winnipeg River subprovince represent originally shallow-dipping thrust faults that were steepened by collision of the two terranes (Beakhouse 2013).

Given the necessity of $10-15 \mathrm{~km}$ of uplift required by the exposed metamorphic facies in the successor basins, their preservation would indicate that they were tectonically buried. The basins are asymmetric: the contact with older greenstones is an unconformity, whereas the 'major break' lies on the other flank of the basin. Using the Abitibi greenstone belt as an example, successor basin stratigraphy youngs south but appears on the north side of these major structures. These patterns are best explained by late-stage thrust burial in which the major extensional 'breaks' became inverted, forming thickskinned thrusts. The association of successor basins with gold mineralization is discussed in a subsequent section. It should be noted that the Bleeker (2012) model does not explain alongstrike variations in the Porcupine-Destor structure east of Timmins (J. Goutier personal communication 2014).

Although the model for successor basin development is based on the Abitibi greenstone belt (Bleeker 2012), similar basins, complete with evidence of extension (alkaline to calc-
A

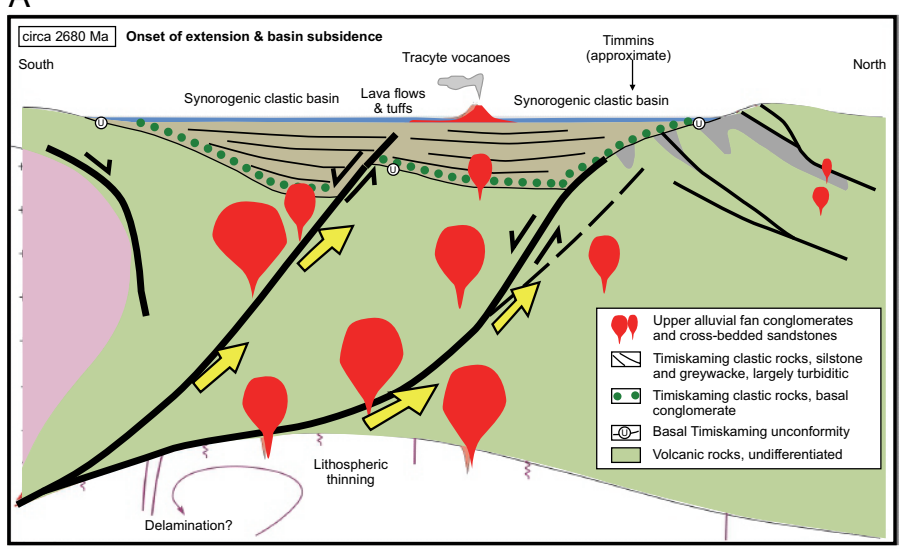

B

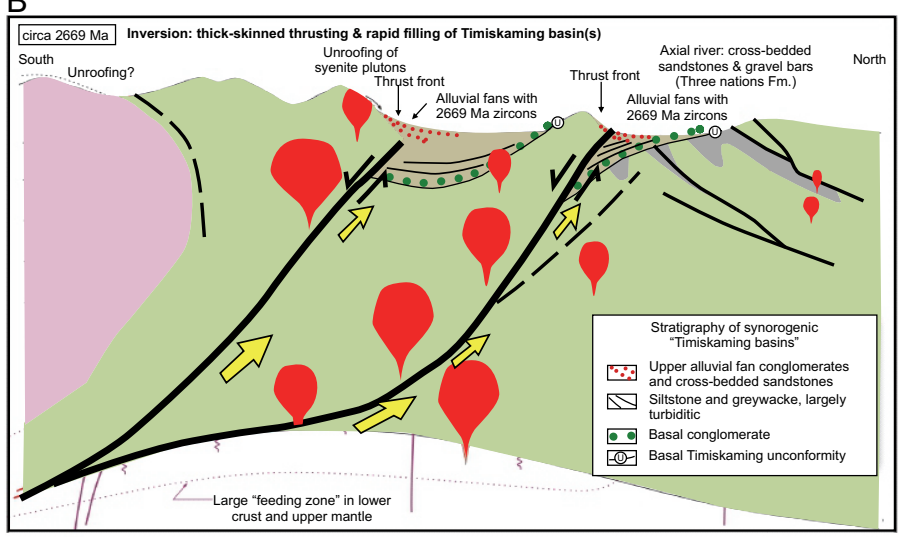

C

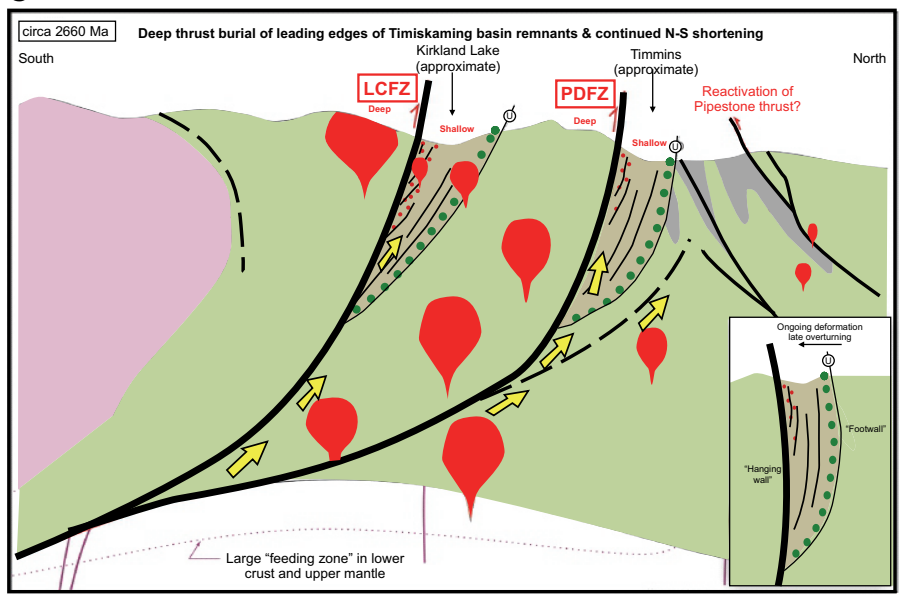

Figure 19. Late structural history of greenstone belts and the place of orogenic gold deposits based on the model of Bleeker (2012). A. Onset of regional extension at $\sim 2680 \mathrm{Ma}$ resulting in development of synorogenic late phases of successor basins. Extension provides access for alkalic magmatism. B. Transition from extension to renewed north-south shortening at ca. $2669 \mathrm{Ma}$ with the major breaks becoming thick-skinned thrusts resulting in burial in the footwall of the clastic basins. C. Deep burial and steepening of thrusts at ca. 2660 Ma. Note that the region south of the basin represents deeper crustal levels exhumed during continued shortening.

alkaline magmatism) exist in the western part of the Wawa-Abitibi terrane (Lodge et al. 2013), in the Wabigoon subprovince (Mueller and Corcoran 1998), and the North Caribou terrane (Brooks et al. 1982; Parks et al. 2006). Similar successor basins exist in the Slave (Bleeker and Hall 2007), Yilgarn (Kositcin et al. 2008), Pilbara (Krapez and Barley 1987), 


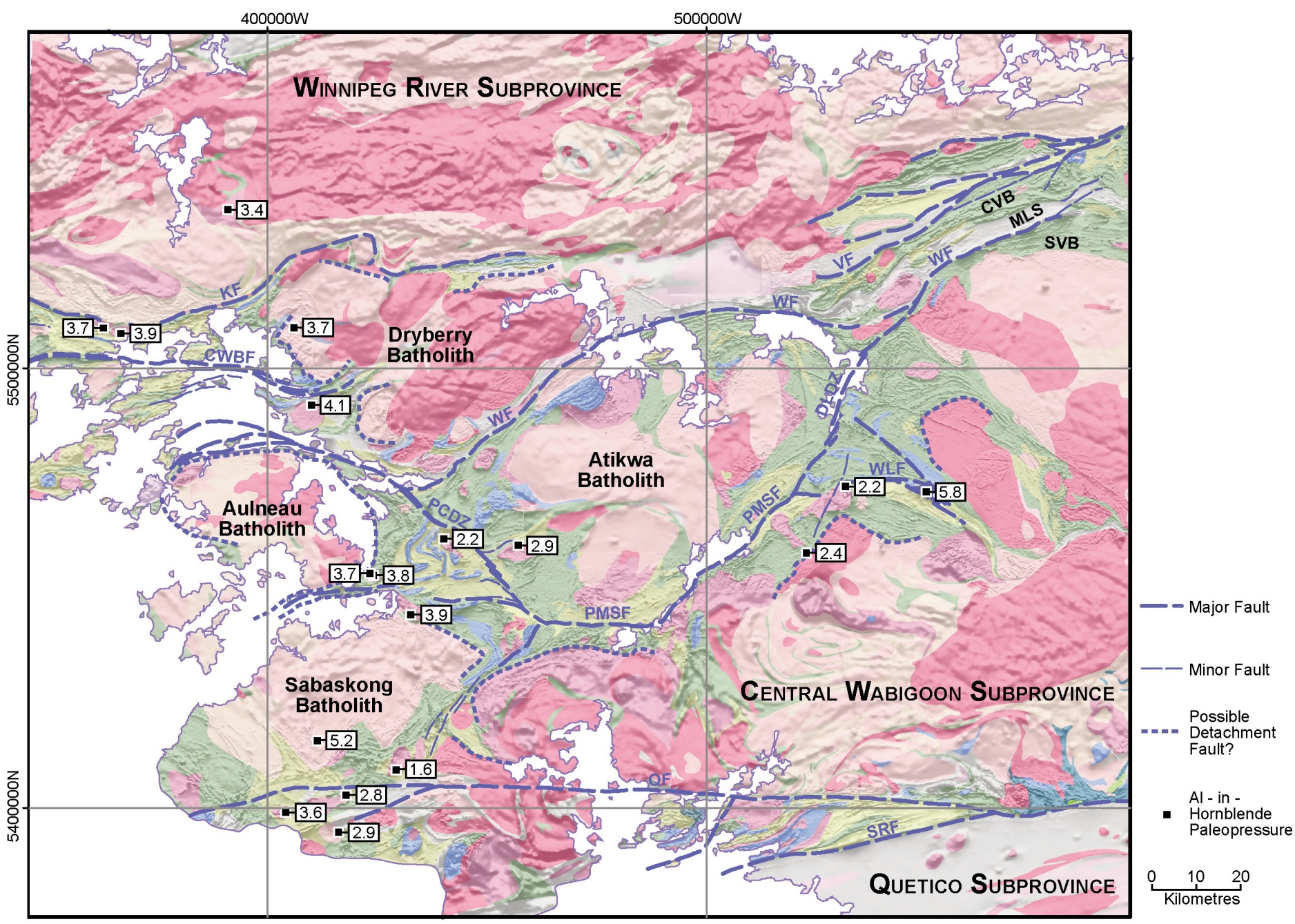

Figure 20. The western Wabigoon subprovince in the southwestern part of the Superior Province. The geology is generalized and draped over a shaded image of the first vertical derivative of the total magnetic field. Dashed lines denote potential detachment faults at the granite-greenstone contacts. Squares show location of aluminum-in-hornblende paleopressure determinations with pressure in kilobars in adjacent boxes. North of the Dryberry batholith, extensional structures are associated with the collision of the Wabigoon subprovince with the older Winnipeg River subprovince to the north (after Beakhouse 2013). The labeled features are: CVB-central volcanic belt; MLS-Minnitaki Lake sediments; SVB-southern volcanic belt; CWBF-Crowduck Lake-Witch Bay fault; DLDZ-Dinorwic Lake deformation zone; KF-Kenora Fault; PCDZ-PipestoneCameron deformation zone; PMSF-Pipestone-Manitou Straits fault; QF-Quetico Fault; SRF-Seine River fault; WF-Wabigoon fault; WLF-Washeibemaga Lake fault; VF-Vermilion fault.

Baltic (Slabunov et al. 2006), and Zimbabwe (Blenkinsop et al. 1997) cratons, among others.

\section{METAMORPHISM}

Metamorphic patterns reveal the thermal and structural history of Archean granite-greenstone terranes. Metamorphism of these terranes is of the low pressure, high temperature type, and isograds are broadly concentric with respect to the major batholiths (Thurston and Breaks 1978; Easton 2000; Fig. 21). The most intensely studied region in terms of metamorphism in the Superior Province is the Abitibi greenstone belt, where $\mathrm{P}_{1}$, a seafloor metamorphism, produced prehnite-pumpellyite assemblages (Jolly 1978; Dimroth and Lichtblau 1979). In places, the early metamorphism includes development of contact aureoles around synvolcanic plutons such as the Flavrian and Powell plutons. These events predate cleavage development (Dimroth et al. 1983). The second metamorphic event in most greenstone belts, $\mathrm{P}_{2}$, consists of up to $5 \mathrm{~km}$-wide contact aureoles imposed on the greenstone belt and early plutonic rocks by intrusion of large TTG plutons and late alkaline plutons (Mortensen 1993). The $\mathrm{P}_{2}$ assemblages overprint the earlier event, though the textural features could be explained by outward progression of the thermal anomalies surrounding granitoid intrusions. Thus, in the most intensely studied region, both burial and contact metamorphic processes are evident (Easton 2000). The metamorphic grade in greenstone belts elsewhere in the Superior Province and on other Archean cratons is in the greenschist to amphibolite facies (Thurston and Breaks 1978; Easton 2000; Goscombe et al. 2012; Bédard et al. 2013). The Abitibi greenstone belt is unusual in having sub-greenschist facies assemblages in the interior of the belt (Powell et al. 1995).

Regional mapping coupled with metamorphic studies demonstrate a systematic variation in structural style and metamorphic pressure (Bédard et al. 2013). At upper crustal levels having low metamorphic pressures, the dome-and-keel structural style predominates. At middle- to deep-crustal levels, greenstones form $<10 \%$ of the crust and TTGs predominate 
among steeply dipping, minor supracrustal enclaves. In deep crust such as the North Atlantic craton, gneissic units and supracrustal enclaves display subhorizontal structures and metamorphic pressures equivalent to 25-30 $\mathrm{km}$ depth (Windley and Garde 2009).

The early metamorphism $\left(\mathrm{P}_{1}\right)$ is the main metamorphic event in the granite-greenstone terranes north and west of the Abitibi-Wawa terrane (Easton 2000; Table 4). The higher-grade granite-greenstone terranes have somewhat later metamorphic events (e.g. $\mathrm{P}_{2}$ ), whereas $\mathrm{P}_{3}$ is the dominant metamorphic event in the southern Superior Province. $\mathrm{P}_{4}$ is present mainly in amphibolite- to granulitefacies areas of the southern WawaAbitibi, Quetico and English River sub-

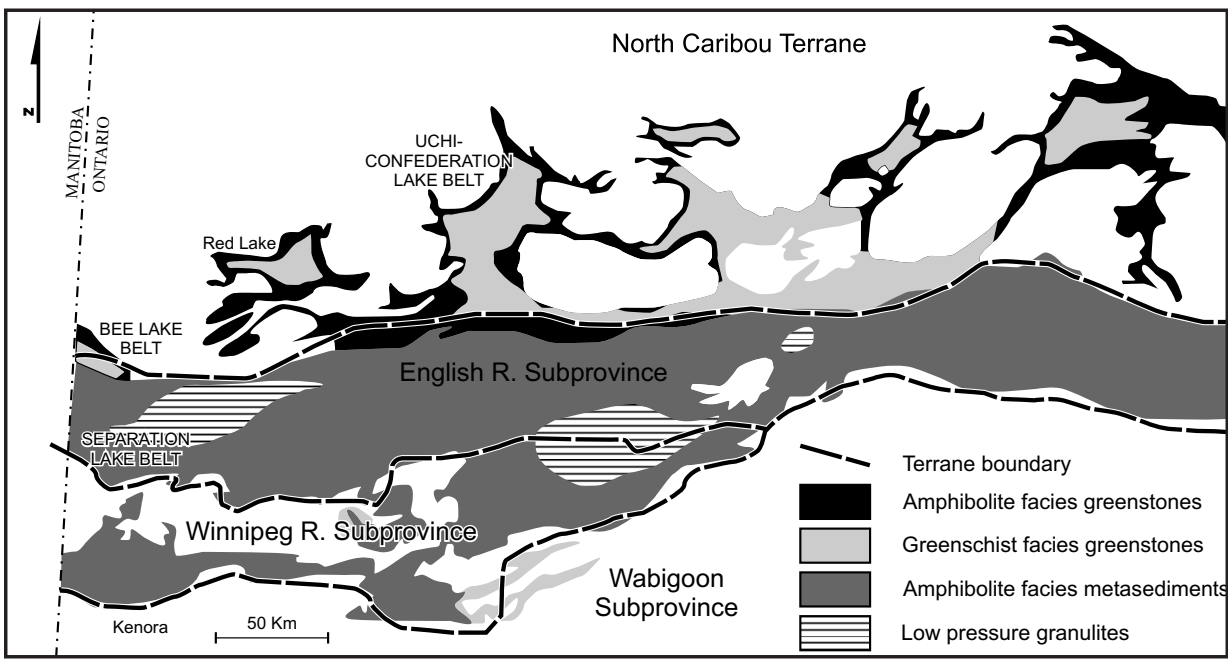

Figure 21. Metamorphic patterns in the southern part of the North Caribou terrane and the English River subprovince (after Thurston and Breaks 1978). provinces (Easton 2000).

Metamorphic discontinuities at major tectonic boundaries, e.g. the North Caribou terrane-English River subprovince boundary (Thurston and Breaks 1978) are abrupt, commonly representing a difference of hundreds of degrees over a horizontal distance of a few metres. Metamorphic variations in the Superior Province indicate that the individual terranes were not tilted; for example, northeastern Québec displays broad areas of uniform metamorphic rank, whereas the metamorphic variation in the Baltic shield (Nehring et al. 2009) suggests that granite-greenstone terranes are large-scale tilted blocks.

\section{GRANITOID ROCKS AND MAFIC/ULTRAMAFIC INTRUSIONS IN GRANITE-GREENSTONE TERRANES}

\section{Introduction}

Granitoid rocks in granite-greenstone terranes are classified based on the system of Le Maitre (1989; Fig. 22), with modifications by Stone (2005). At a regional scale, the granitoid rocks surrounding greenstone belts in the Superior Province are subdivided into: 1) gneissic tonalite, 2) foliated tonalite, 3) granite, 4) peraluminous granite, and 5) sanukitoid suite plutons (Stone 2005; Table 5).

With minor variations in nomenclature, these subdivisions are present in all Archean cratons (Pawley et al. 2004; Martin et al. 2005). The gneissic tonalite suite commonly connects greenstone remnants in high-grade metamorphic zones in the northwestern and northeastern Superior Province (Percival et al. 1994; Stone 2005). The foliated tonalite suite, made up of biotite tonalite and hornblende tonalite, constitutes about 50\% of the crust in northwestern Ontario (Stone 2005, 2010). It makes up greater proportions of the crust in areas of higher metamorphic grade, e.g. in northern Québec (Bédard et al. 2013). The dominant geochemical type of tonalite is the highAl type of Martin (1993), which is produced in the garnet stability field, whereas in the East Pilbara terrane (Champion and Smithies 2007) and in the Baltic shield (P. Holtta personal communication 2009), both high- and low-Al types occur. Peraluminous granites form elongate to irregular bodies commonly found along major structures, e.g. along the Bearhead fault zone (Thurston et al. 1991). The sanukitoid suite intru-

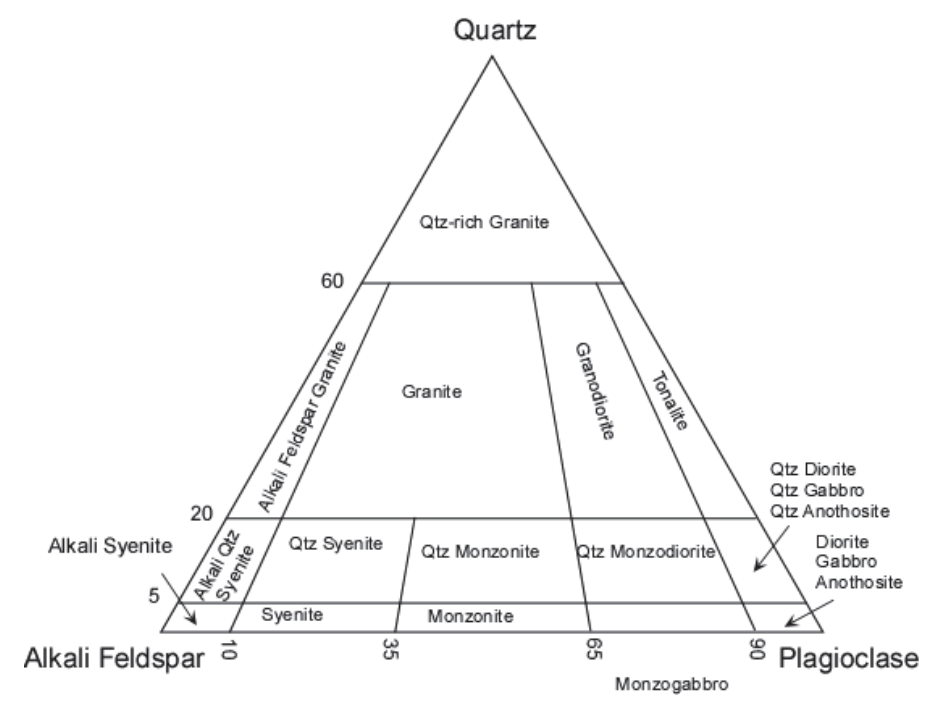

Figure 22. Classification of granitic rocks (after Le Maitre 1989).

sions occur in quasi-linear arrays along major strike-slip structures and along terrane boundaries (Thurston et al. 1991). The proportions of the various suites are a function of exposure level; the northern Superior Province represents mid-crustal depth (Stone 2005) and the northeastern Superior Province a somewhat deeper level wherein the proportion of tonalites increases slightly (Bédard et al. 2003, 2013). At higher crustal levels, such as in the Wawa-Abitibi terrane (Sutcliffe et al. 1993), the proportion of granite suite plutons increases slightly.

\section{Age Relationships of Archean Granitoid Rocks vs. Greenstones}

Granitoid units in Archean granite-greenstone terranes range in timing of emplacement from synvolcanic to syn-tectonic to post-tectonic. In rare instances, where not overprinted by later structures or intrusions, granitoid rocks form basement to greenstones (Wilks and Nisbet 1988; Bickle et al. 1993). In a mechanical sense, kinematic indicators show that, at the granitoid-greenstone interface, the sense of motion is batholithup and greenstones-down (Stott and Corfu 1991; Pawley et al. 
Table 4. Bathozones in the Superior Province (after Easton 2000).

\begin{tabular}{|c|c|c|c|}
\hline \multirow[t]{2}{*}{ Event } & \multicolumn{3}{|c|}{ Bathozone (depth in crust) } \\
\hline & $1-2(3-8 \mathrm{~km})$ & $3-4(9-14 \mathrm{~km})$ & $5-6(15-24 \mathrm{~km})$ \\
\hline \multicolumn{4}{|l|}{ P1 } \\
\hline $2710-2695 \mathrm{Ma}$ & $\begin{array}{l}\text { NW Superior (N. Caribou terrane) } \\
\text { Wabigoon, Eastern Wawa-Abitibi } \\
\text { (Abitibi greenstone belt) }\end{array}$ & Southern Winnipeg River & Quetico \\
\hline \multicolumn{4}{|l|}{ P2 } \\
\hline $2693-2680 \mathrm{Ma}$ & Central Wawa-Abitibi & English River, northern Winnipeg River & Kapuskasing, Pikwetonei \\
\hline \multicolumn{4}{|l|}{ P3 } \\
\hline $2678-2665 \mathrm{Ma}$ & $\begin{array}{l}\text { Western Quetico, Eastern Wawa- } \\
\text { Abitibi }\end{array}$ & $\begin{array}{l}\text { SW Abitibi, English river, northern } \\
\text { Winnipeg River, Wawa, central and } \\
\text { eastern Quetico }\end{array}$ & South-central Quetico \\
\hline \multicolumn{4}{|l|}{ P4 } \\
\hline $2660-2648 \mathrm{Ma}$ & & $\begin{array}{l}\text { North-central Wawa-Abitibi, } \\
\text { Central Wawa-Abitibi gneisses }\end{array}$ & $\begin{array}{l}\text { South central Quetico } \\
\text { granulites, Kapuskasing, } \\
\text { eastern Wawa-Abitibi } \\
\text { gneisses, Levack } \\
\text { granulites }\end{array}$ \\
\hline \multicolumn{4}{|l|}{ P5 } \\
\hline$<2640 \mathrm{Ma}$ & & & $\begin{array}{l}\text { Eastern Kapuskasing, } \\
\text { western Pikwetonei }\end{array}$ \\
\hline
\end{tabular}

Table 5. Regionally important Granitoid types in the Superior Province (after Stone 2005).

\begin{tabular}{|c|c|c|c|c|}
\hline Suite & Rock types & Fabric & $\begin{array}{l}\text { Form/Occurrence } \\
\text { and } \% \text { of area }\end{array}$ & Inclusion types \\
\hline Gneissic Tonalite & $\begin{array}{l}\text { Biotite }+ \text { hornblende } \\
\text { tonalite to granodiorite }\end{array}$ & $\begin{array}{l}\text { Foliated, layered, } \\
\text { folded }\end{array}$ & $\begin{array}{l}\text { Belts, masses; scattered } \\
\text { near greenstone } \\
\text { remnants 3\% }\end{array}$ & Supracrustal xenoliths \\
\hline Foliated Biotite Tonalite & $\begin{array}{l}\text { Biotite tonalite to } \\
\text { granodiorite }\end{array}$ & $\begin{array}{l}\text { Foliated to gneissic; } \\
\text { quartz and feldspar } \\
\text { megacrystic }\end{array}$ & $\begin{array}{l}\text { Irregular to crescentic } \\
\text { and lobate bodies; } \\
\text { scattered } 34 \%\end{array}$ & $\begin{array}{l}\text { Amphibolite, } \\
\text { supracrustal xenoliths }\end{array}$ \\
\hline $\begin{array}{l}\text { Foliated Hornblende } \\
\text { Tonalite }\end{array}$ & $\begin{array}{l}\text { Hornblende }+ \text { biotite } \\
\text { tonalite to granite }\end{array}$ & $\begin{array}{l}\text { Foliated; granular; } \\
\text { feldspar megacrystic }\end{array}$ & $\begin{array}{l}\text { Irregular to elongate } \\
\text { bodies of variable size; } \\
\text { scattered; } 14 \%\end{array}$ & $\begin{array}{l}\text { Lensoid dioritic } \\
\text { inclusions }\end{array}$ \\
\hline Biotite Granite & $\begin{array}{l}\text { Biotite granodiorite } \\
\text { to granite }\end{array}$ & $\begin{array}{l}\text { Massive to weak } \\
\text { magmatic layering }\end{array}$ & $\begin{array}{l}\text { Dikes, irregular masses, } \\
\text { oval batholiths; scattered } \\
30 \%\end{array}$ & $\begin{array}{l}\text { Biotite tonalite, } \\
\text { amphibolite }\end{array}$ \\
\hline Peraluminous (S-type) & $\begin{array}{l}\text { Biotite }+ \text { muscovite } \\
\text { granodiorite to granite }\end{array}$ & Massive; mylonitic & $\begin{array}{l}\text { Elongate to irregular } \\
\text { bodies }<1 \%\end{array}$ & Sediment \\
\hline Sanukitoid & $\begin{array}{l}\text { Biotite }+ \text { hornblende+ } \\
\text { pyroxene quartz diorite, } \\
\text { tonalite, quartz } \\
\text { monzodiorite, } \\
\text { granodiorite, quartz } \\
\text { monzonite, quartz } \\
\text { syenite, granite }\end{array}$ & $\begin{array}{l}\text { Massive to weak } \\
\text { magmatic layering }\end{array}$ & Oval plutons $4.5 \%$ & $\begin{array}{l}\text { Hornblendite, } \\
\text { amphibolite }\end{array}$ \\
\hline
\end{tabular}


2004; Van Kranendonk et al. 2004; Robin and Bailey 2009). In granite-greenstone terranes worldwide, there is a regular progression from TTG units to true granites followed by sanukitoid plutons, as shown by relationships in the North Caribou terrane (Corfu and Stone 1998; Fig. 23), the Superior craton in northeastern Québec (Bédard et al. 2003), and the Pilbara craton (Van Kranendonk et al. 2004). Geochronology linked with phase-byphase mapping of granitoid plutons and structural geology is not commonly done in granite-greenstone terranes, with some notable exceptions (Corfu and Stone 1998; Van Kranendonk et al. 2004; Stone 2005). Early units occur at the margins of batholiths and younger phases in the central zones in the East Pilbara craton (Van Kranendonk et al. 2004), the Wabigoon subprovince (Stone 2010), and the northern Superior Province (Stone 2005). A limited number of so-called 'late crescentic plutons' intruded along the interface between greenstones and granitoid rocks in the Wabigoon subprovince (Stott 1986). A more robust dataset indicates that the granite batholiths post-dated the tonalitic rocks and feature Al-in-hornblende barometry demonstrating that they crystallized at lower pressures than the surrounding, more abundant tonalites (Stone 2005, 2010).

Using integrated geochronology and Al-in-hornblende data on pressure at the time of emplacement, Beakhouse et al. (2011) demonstrated that after emplacement of the syntectonic phases of the Pukaskwa batholith, the batholith was uplifted as a structural dome. Similar features are seen in the Shaw batholith in the Pilbara craton (Pawley et al. 2004; Van Kranendonk et al. 2004). In a general sense, integrated studies of petrogenesis, structural geology and geochronology (Corfu and Stone 1998; Whalen et al. 2004) show that low-K granitoid rocks precede tectonism and that high-K granitoid rocks followed the major deformation events.

\section{Mafic/Ultramafic Intrusions}

Mafic to ultramafic intrusions occur across the Superior craton as synvolcanic to post-tectonic intrusions generally a few hundred metres to a few kilometres in diameter. The synvolcanic intrusions represent komatiitic to tholeiitic magmatism as synvolcanic sills, dikes and plutons (e.g. Kuiper 2010). Larger, and somewhat later, layered to massive mafic to ultramafic plutons are found cutting the volcanic units of greenstone belts across the Superior craton (Barrie et al. 1990; Jackson and Fyon 1991; Sappin et al. 2013). These intrusions vary from basaltic to ultramafic and range from synvolcanic to post-tectonic. An excellent example of large intrusions of synvolcanic age in the Abitibi greenstone belt is the Bell River Complex, a subvolcanic intrusion in the Matagami district (Maier et al. 1996). These intrusions bear no particular relationship to stratigraphy or structure at a large scale. Post-tectonic, kilometre-scale mafic/ultramafic intrusions are broadly associated with major tectonic boundaries in granite-greenstone terranes. These intrusions vary from concentrically zoned bodies to rather conventional layered complexes. The primary magma for the concentrically zoned Lac des Iles intrusion in the Marmion terrane is basaltic (Sutcliffe et al. 1989). A string of post-tectonic, concentrically zoned, ultramafic to mafic small intrusions are scattered along the interface between the Quetico subprovince and the western Wabigoon subprovince to the north (Pettigrew and Hattori 2006); their emplacement may well be tectonic (Devaney and Williams 1989a; Pettigrew and Hattori 2006). 


\section{Petrogenesis}

\section{Tonalite-Trondhjemite-Granodiorite Suite (TTGs)}

Archean batholiths of the T'TG suite vary from the dominant high-Al type (Martin 1987; Martin et al. 2005) displaying fractionated REE patterns, to less common low-Al type TTGs with less fractionated REE patterns. The lack of significant Eu anomalies and a lack of correlation between $\mathrm{Eu}^{*}$ and $\mathrm{MgO}$ or $\mathrm{SiO}_{2}$, particularly in the high-Al type, suggests that fractional crystallization within the plagioclase stability field was not a major process (Stone 2005, 2010; Champion and Smithies 2007). The Si-rich, low-Al T'TGs do show evidence consistent with at least some fractional crystallization (Bagas et al. 2003). However, the consensus is that TTGs in general represent the partial melting of a mafic precursor (Barker and Arth 1976; Drummond and Defant 1990), and that variations in the LREE/HREE values reflect melt production in the garnet stability field (high values) or the plagioclase stability field (lower values). Champion and Smithies (2007) modelled the derivation of high-Al T'TGs in the East Pilbara terrane by relatively modest degrees $(\sim 20 \%)$ of melting of low-K tholeiitic basalt from the neighbouring greenstone belts. They note that more enriched starting materials are required to produce the more LILE-rich granitoid rocks. Their modelling requires a residual phase retaining $\mathrm{Nb}$, $\mathrm{Ti}$ and $\mathrm{Ta}$ (perhaps amphibole), or a source that has been depleted in $\mathrm{Nb}$ and Ti. The high-Al TTGs can be produced in a similar way from a garnet-free residue containing 20-40\% residual plagioclase.

Using actualistic models, Martin $(1993,1999)$ promoted the generation of TTGs by melting of subducted slabs in what is known as the 'adakite' model, based on geochemical similarities to adakites. Alternatively, trace element modelling has shown that the elevated $\mathrm{La} / \mathrm{Yb}$ and $\mathrm{Sr} / \mathrm{Y}$ signature of TTGs can be explained by hornblende fractionation of a tonalitic parent melt (Bédard 2006). Further consideration of major element modelling (Bédard et al. 2013) suggests that a maximum of $25 \%$ fractionation is possible given the low abundances of $\mathrm{FeO}$ and $\mathrm{MgO}$ in TTGs. However, when these approaches are combined with $\varepsilon N d$ data, Champion and Smithies (2007) conclude that some form of intermediate to felsic crustal component is also required along with a basaltic protolith. The isotopic data in this instance also show that contributions to TTG melts had a crustal residence time of as much as 200 m.y. Similar results are seen in $\mathrm{Sm}-\mathrm{Nd}$ studies of Superior craton granitoid rocks (Henry et al. 1998).

In summary, partial melting of a basaltic protolith at varying pressures controls the residual mineralogy and thus the geochemistry of the TTG suite. The existence of 'TTGs with high LILE, Th and U requires a source richer in LILE than typical Archean basalts. Therefore, the two types of TTGs may well reflect crustal thickness, the high-Al type indicating thicker Archean crust (Champion and Smithies 2007). The lack of high $\mathrm{Mg \# ,} \mathrm{Cr}$ and $\mathrm{Ni}$ in high-Al TTGs probably precludes interaction with the mantle wedge (Champion and Smithies 2007) and instead suggests partial melting of thickened mafic crust, which is also seen in younger terranes (Gromet and Silver 1987). There are contrasting opinions that call upon subduction processes (Moyen and Stevens 2006; Laurent et al. 2014); however, representative crustal thickness beneath the
Superior (White et al. 2003) and Pilbara (Drummond 1988) cratons $(\sim 40 \mathrm{~km})$ and the dominantly felsic nature of that crust preclude the presence of mafic-ultramafic residua in the production of tonalite. Therefore, some form of recycling such as delamination (Smithies and Champion 1999) is required.

The high-alumina TTGs are explained (Wyman et al. 2011) by hornblende and titanite fractionation. If TTGs with high $\mathrm{Sr} / \mathrm{Y}$ or $\mathrm{La} / \mathrm{Yb}$ are not residua from fractionation of tonalites, then they must represent very small degrees of partial melting. But if adakites and tonalites are produced by slab melting, these small degree melts do not explain the large proportions of TTGs that characterize granite-greenstone subprovinces (Bédard et al. 2013). Fundamentally, the total variability of high- and low-Al tonalites is best explained by genesis at various temperatures and pressures. For example, Nehring et al. (2009) explain the variety of T'TGs in the Baltic shield in terms of the melting of granulites and amphibolites.

\section{Granodiorite to Granite}

The last phase of granitoid magmatism is the broadly post-tectonic intrusion of granodiorite to granite. Conventional petrogenetic arguments indicate that granites are produced by melting of pre-existing granitic units, based on trace elements and $\mathrm{Nd}$ isotope systematics (Whalen et al. 2004). The granites consistently display negative $\mathrm{Nb}$ and $\mathrm{Ti}$ anomalies (Stone 2005, 2010), which can be explained by retention of trace minerals in residua, enrichment in adjacent trace elements, or a contamination, as discussed previously. The granite suite in northwestern Ontario is marginally peraluminous, indicating a petrogenetic link to the peraluminous granite suite and implying that these characteristics are present in the source, in turn suggesting that the source for this suite is perhaps the biotite tonalite suite (Stone 2005). The presence of depletions in Sr, Ba and $\mathrm{Eu}$, and general REE enrichment is consistent with feldspar fractionation. Isotopic studies (Whalen et al. 2004) indicate that the late, high-K granitoid rocks have $\varepsilon N d$ values of -3.1 to +3.3 , demonstrating that the K-rich granitoid rocks are produced with input from LREE-enriched older crustal materials and juvenile material. This suggests melting of older crust and young infracrustal material. Lastly, the biotite granite suite includes REE-enriched and REE-depleted units similar to those elsewhere in the Superior Province, implying a broadly similar petrogenesis across the Superior Province.

\section{Peraluminous Granites}

Peraluminous leucogranites are commonly found along major tectonic boundaries, e.g. within the North Caribou terrane (Stone 2005) and along the boundaries of the Wabigoon, Winnipeg River and English River terranes (Breaks and Moore 1992). The values of $\varepsilon N d$ vary from -2 to +2 for the leucogranite suite in the Wabigoon terrane, overlapping values for nearby metavolcanic and metasedimentary units. Thus, Larbi et al. (1999) concluded that the leucogranite suite was developed from both mantle and crustal sources. The leucogranite suite from across the Superior Province is ca. $2650 \mathrm{Ma}$ in age (Larbi et al. 1999; Percival and Stott 2010), suggesting that this suite may be related to a large-scale process such as crustal delamination (Percival et al. 2004). 


\section{Sanukitoid Suite}

The sanukitoid suite of plutonic rocks was defined by Shirey and Hanson (1986) as follows: $\mathrm{SiO}_{2}<60 \%, \mathrm{MgO}>6 \%, \mathrm{Mg} \#$ $>0.6, \mathrm{Cr}>100 \mathrm{ppm}$, Sr and $\mathrm{Ba}>500 \mathrm{ppm}$, and high $\mathrm{Na}_{2} \mathrm{O}, \mathrm{K}_{2} \mathrm{O}$, LREE, and $\mathrm{La} / \mathrm{Yb}$. This suite ranges in composition from dioritic to granodioritic. The high $\mathrm{Cr}, \mathrm{Ni}$ and $\mathrm{K}_{2} \mathrm{O}$ distinguish this suite from TTGs and mandate a mantle origin, yet high contents of LILE suggest a more complex origin. Modelling summarized in Martin et al. (2005) demonstrates that sanukitoids cannot be produced by contamination of
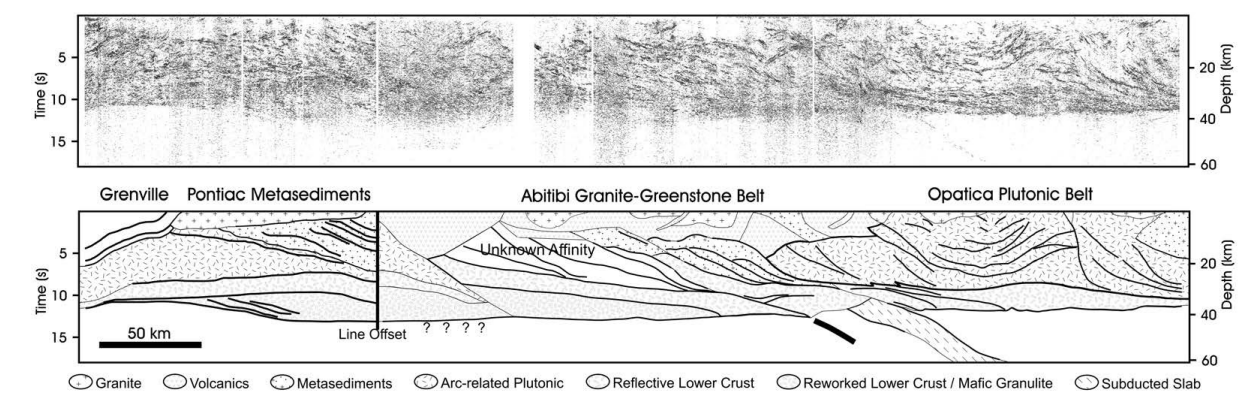

Figure 24. A reflection seismic profile of the Abitibi greenstone belt and the Opatica gneisses to the north, showing north-dipping reflections in the Opatica gneisses interpreted by Calvert and Ludden (1999) as subduction scars. komatiitic or basaltic magmas by LILE-

rich felsic crust, as that scenario does not explain coincident high $\mathrm{Cr}, \mathrm{Ni}$ and LILE. Therefore, the less-evolved sanukitoids must represent a peridotitic source, but any mantle source must also account for the high $\mathrm{SiO}_{2}$ and LILE. Given the similarities with TTGs and adakites (high LILE, fractionated REE patterns, low $\mathrm{Yb}$ and $\mathrm{Y}$ concentrations), these characteristics are interpreted to represent slab melting (Martin et al. 2005); however, the possibility of melting of fertilized mantle has also been postulated (Shirey and Hanson 1986). Sanukitoid intrusions in Archean cratons are post-tectonic and, for example, in the Superior craton, they are spatially associated with major terrane-bounding, strike-slip shear zones.

\section{GEOPHYSICS OF GRANITE-GREENSTONE TERRANES}

\section{Introduction}

Granite-greenstone terranes have been investigated using a variety of geophysical techniques. Early magnetic surveys optimized for regional mapping clearly distinguished greenstone belts from the surrounding granitoid rocks (Gupta 1991). Gravity maps and gravity modelling of granite-greenstone terranes have shown that the depth to tonalitic basement varies from $10-12 \mathrm{~km}$ in the low metamorphic grade Abitibi greenstone belt (Peschler et al. 2004; Benn and Peschler 2005) to about $5 \mathrm{~km}$ in the case of the Birch-Uchi greenstone belt in the North Caribou terrane (Gupta et al. 1982). Studies of seismic anisotropy (Silver and Chan 1991; Ferguson et al. 2005) have shown that the structural trends of greenstone belts persist into the upper mantle.

\section{Reflection Seismic Studies}

Reflection seismic studies of the Superior craton carried out as part of the LITHOPROBE project (summarized by Percival et al. 2004, 2006) indicate that Superior craton crust is about 40 $\mathrm{km}$ thick. Dipping structures interpreted as 'subduction scars' occur along the Abitibi-Grenville seismic line, the western Superior Province line, and the Slave Province line (van der Velden and Cook 2005; Fig. 24). Calvert et al. (2004) have developed a model in which the southern part of the North Caribou terrane (the former Uchi subprovince) is preserved at relatively low metamorphic grade along a south-dipping extensional shear zone truncating sub-horizontal reflectors in the interior of the North Caribou terrane gneisses. These authors note that early vertical tectonics is still possible and also note that the extensional event they portray is related to orogenic gold mineralization in the Uchi subprovince. However, numerical models of crustal processes (Gray and Pysklywec 2010) suggest that the features imaged can develop by shortening without subduction or accretion, although these authors invoke the production of "plate-like mantle lithosphere at depths of 200-400 km," which may be interpreted as a possible early version of plate tectonics. The LITHOPROBE seismic profiles display few details of greenstone belt structure, although more recent detailed reflection seismic profiles specifically designed to image greenstone belt structure are revealing (Snyder et al. 2008). These studies do not image the prevailing vertical foliations of greenstone belts, but do show structures with dips of $<\sim 60^{\circ}$. Therefore, the shallowly dipping strata found in anticlinal domes are clearly revealed and it can be seen that seismically transparent units coring these domes are likely granitoid rocks (Fig. 25). Steeply dipping features such as the gold-associated Porcupine-Destor fault zone are imaged by virtue of the offset of greenstone belt stratigraphy and are seen to have a listric geometry at depth, passing at a depth of a few $\mathrm{km}$ into locally-developed antiformal thrust stacks (Snyder et al. 2008).

Similar seismic surveys designed to optimize the detail near greenstone-hosted gold deposits in the Yilgarn craton have been able to trace detachment faults at $4-7 \mathrm{~km}$ depth (i.e. at the base of the supracrustal rocks) that pass into a network of faults trending upward through the greenstones to sites of lode gold deposits (Goleby et al. 2004, 2006). Seismic profiles in the Superior Province lack the combination of detail and depth extent to enable similar interpretations.

\section{RELATIONSHIP OF GRANITE-GREENSTONE TERRANES TO SEDIMENTARY SUBPROVINCES}

Sedimentary subprovinces (Card 1990) are linear belts of largely amphibolite- to low-pressure granulite-facies clastic metasedimentary rocks that were termed orogenic flysch by Percival and Stott (2010). Typical examples are the English River, Quetico, Opinaca and Ashuanipi subprovinces in the Superior craton, and the Limpopo sedimentary rocks at the junction between the Kaapvaal and Zimbabwe cratons (Eglington and Armstrong 2004). Geochronological work indicates that the metasedimentary units are coeval with successor basin sedimentary rocks (Davis 1990; Davis et al. 1990). In numerous places in the Superior Province, sedimentary subprovince clastic units overlie greenstones (Breaks 1991; Williams 1991). 

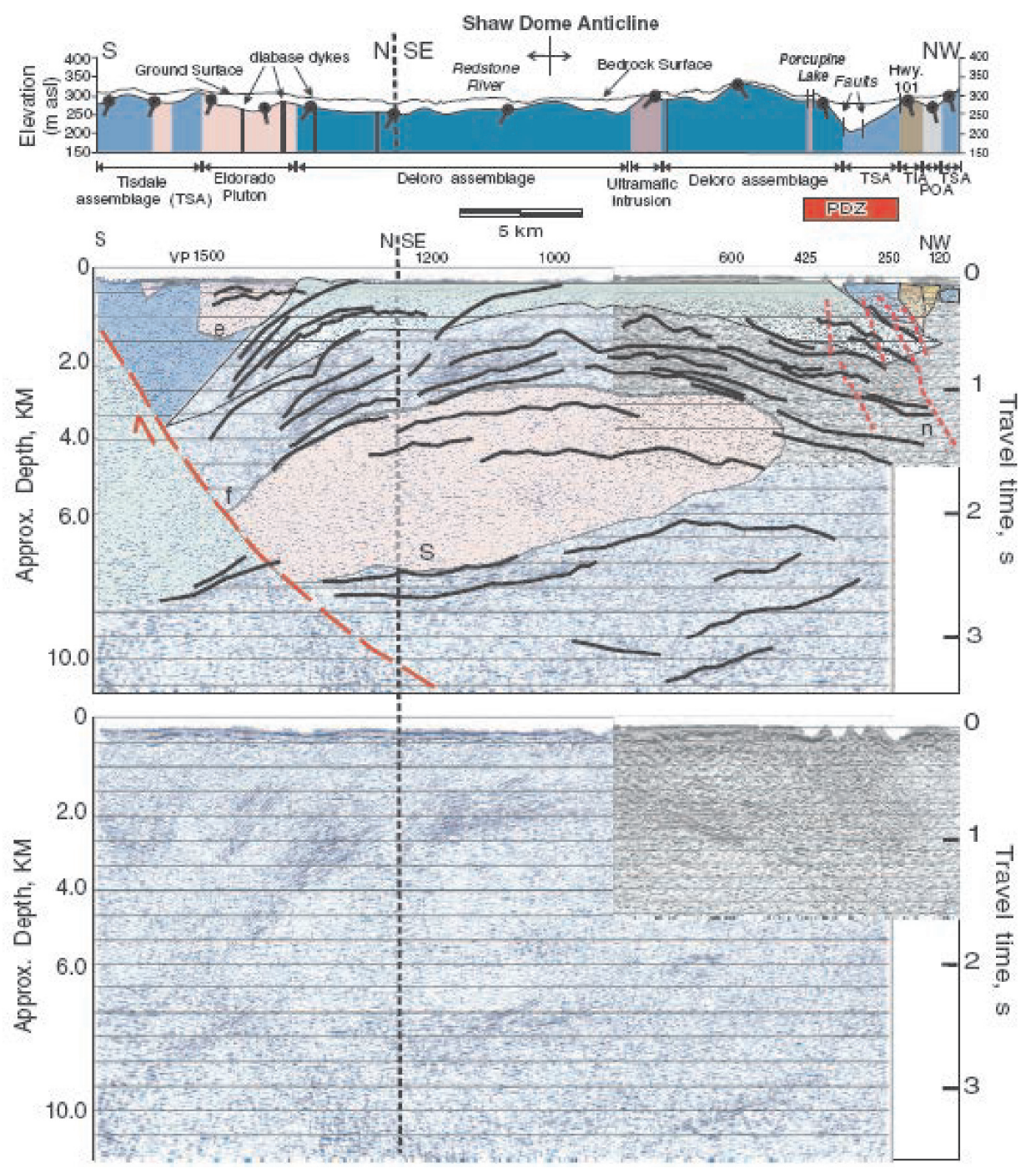

Figure 25. Shaw Dome reflection seismic line in the Abitibi greenstone belt (after Snyder et al. (2008) The data shows reflections from quasi-horizontal greenstone units over the Shaw Dome, a regional anticline south of Timmins, and a seismically transparent, nearly horizontal granitoid intrusion which bowed up the greenstones of the Deloro assemblage.

The sedimentary detritus is derived both from the adjacent granite-greenstone terranes and also from more distal and older plutonic terranes (Sanborn-Barrie and Skulski 2006; Percival 2007; Percival and Stott 2010). Structural and metamorphic studies indicate that the sedimentary subprovinces transition southward from lower-grade northern margins to highergrade zones via extensive thrust telescoping (Devaney and Williams 1989; Hrabi and Cruden 2006). Structural mapping has also demonstrated that the strike-slip faults now bounding the sedimentary subprovinces are relatively late structures (Hrabi and Cruden 2006). Similar relationships are seen for the Limpopo sedimentary rocks and their relationship to the Kaapvaal and Zimbabwe cratons (Eglington and Armstrong 2004).

\section{ORE DEPOSITS}

Archean cratons are a major repository for mineral deposits. The major syngenetic deposit types are VMS deposits and komatiite-associated $\mathrm{Cu}-\mathrm{Ni}$-platinum group element (PGE) deposits. Other important types of mineralization in Archean granite-greenstone terranes are orogenic gold deposits, intrusion-hosted $\mathrm{Cu}-\mathrm{Ni}-$ PGE and Cr deposits, and pegmatite-hosted rare metal deposits.

\section{Volcanogenic Massive Sulphide (VMS) Deposits}

Knowledge of stratigraphy is critical to evaluation of likely locales for VMS deposits. VMS deposits require subvolcanic pluton-centred hydrothermal circulation, largely during periods of volcanic quiescence (Franklin et al. 2005; Galley et al. 2007a). They are commonly associated with development of calderas in later stages of the evolution of major Archean volcanic systems at Noranda (Gibson and Watkinson 1990) and Sturgeon Lake (Hudak et al. 2003) in the Superior Province, although many VMS deposits are not associated with calderas (Allen et al. 2002; Ross and Mercier-Langevin 2014). The deposits consist of massive to disseminated chalcopyrite, sphalerite and pyrite forming massive lenses deposited on the seafloor, and subjacent stockwork vein systems representing zones of hydrothermal upwelling responsible for the seafloor deposits (Galley 2007a). The hydrothermal processes produced zones of metal leaching in sub-deposit semiconformable alteration zones. The metal content of the deposits is a function of the temperature and $\mathrm{pH}$ of the hydrothermal system; hotter systems are more $\mathrm{Cu}$-rich and shallow water systems are possibly more gold-rich (Galley et al. 2007a).

Ore deposits can provide some insight into the geodynamic setting of greenstone belts in that modern VMS deposits, for example, are currently forming in a restricted range of settings (Franklin et al. 2005), e.g. oceanic arcs, back arcs, rifted suprasubduction zone epicontinental arcs, and mature epicontinental back arcs. On the modern seafloor, over $50 \%$ of VMS deposits are on ocean ridges (Hannington et al. 2005; Shanks and Thurston 2012). However, there is much debate as to the possible existence of preserved Archean oceanic floor; on one hand, many authors describe possible examples (Manikyamba and Naqvi 1998; Terabayashi et al. 2003; Shibuya et al. 2012), whereas a minority state that no unequivocal ocean floor of Archean age has been identified (Bickle et al. 1994; Bédard et al. 2013; Kamber 2015). Most interpretations of Archean VMS deposits relate them to oceanic arcs and back arcs (Franklin et al. 2005). Of the VMS deposits in the Superior Province, epicontinental arc and back arc settings are favoured by some, largely based on geochemical studies (Polat et al. 1998).

\section{Komatilite-Associated $\mathrm{Cu}-\mathrm{Ni}$-PGE Mineralization}

Komatiite-associated $\mathrm{Cu}-\mathrm{Ni}-\mathrm{PGE}$ mineralization occurs in two styles: 1) basal massive to disseminated (type I of Lesher 
and Keays 2002); and 2) stratabound, internally disseminated (type II of Lesher and Keays 2002). Controlling the presence of mineralization are parameters such as magma composition, the presence of a suitable substrate in which to develop erosional channels later filled with mineralization, and the physical volcanology (Lesher 1989; Sproule et al. 2002, 2005). In the komatiite-tholeiite sequences, sulphur-undersaturated melts achieve sulphur saturation near surface, commonly by processes such as assimilation of iron-formation or graphitic argillites. Particularly well known examples of this style of mineralization are the nickel deposits of the Kambalda area of the Yilgarn craton (Lesher 1989; Hill 2001) and the deposits of the Abitibi greenstone belt of the Superior craton (Houle et al. 2001, 2008a, 2009; Sproule et al. 2002). Similar mineralization is known in Zimbabwe (Prendergast and Wingate 2013).

\section{Orogenic Gold Deposits}

Epigenetic gold deposits are variously known as lode gold deposits (Poulsen et al. 2000), mesothermal gold deposits, and orogenic gold deposits (Goldfarb et al. 2005). Mineralization is syn- to late-deformational, post metamorphic peak, and associated with regional-scale alteration, hence the term 'orogenic gold' is preferred. They occur mainly in tholeiitic and variolitic basalts and iron-formation units, proximal to the major transcurrent structures forming the faulted margins of successor basins within Archean greenstone belts (Robert and Poulsen 1997; Poulsen et al. 2000; Dubé et al. 2004; Goldfarb et al. 2005; Dubé and Gosselin 2007). There are rare examples almost wholly within metasedimentary units (e.g. Gaillard et al. 2014). The deposits are associated with regional-scale Fe-carbonate and silica alteration of greenstone belt units (Dubé and Gosselin 2007). The mineralization occurs in quartz or quartzcarbonate fault-fill vein arrays, hydrothermal breccias, and shallowly dipping extensional veins cutting the greenstones. The deposits are hosted in greenschist- to amphibolite-facies metamorphic rocks, reflecting development at an intermediate depth of $5-10 \mathrm{~km}$, and thus represent temperatures of $325-$ $400^{\circ} \mathrm{C}$ (Goldfarb et al. 2005). Gold is confined to the vein and breccia systems, but given recent increases in the price of gold, not only are the vein arrays economic, but extensive hydrothermal aureoles around the vein systems are also exploited (e.g. Gaillard et al. 2014). The timing of this style of mineralization varies systematically across complex cratons such as the Superior Province, in which the age of deposits becomes younger from north to south (Fyon et al. 1992). The timing is also synchronous with magmatism spatially associated with major transcurrent faults cutting the greenstone belts and successor basins, representing the later stages of greenstone belt tectonism. Berger (2001) has shown that post-Archean vertical movements along the Porcupine-Destor fault have exposed along-strike variability in the style of gold mineralization. The deposit style along this structure varies from brittle in the west to ductile to the east, and deposit style varies within fault segments that are bounded by Proterozoic crosscutting structures.

Syngenetic models for orogenic gold deposits are no longer viable (Goldfarb et al. 2005), although gold may have been added to the greenstone belt system through seafloor hydrothermal processes producing Au-rich pyrite (Large et al. 2011). Gold transport and deposition are probably related to metamorphic processes, given the $\mathrm{CO}_{2}$ - and S-rich nature of the fluids, the decrease in abundance of gold-associated elements (As, Sb, W, Ba, etc.) as metamorphic grade increases, and the association of these deposits with greenschist- to amphibolite-grade metamorphism (Goldfarb et al. 2005). Bleeker (2012) relates the gold-mineralizing event to regional-scale extension of the greenstone belts, given the association with alkaline to calc-alkaline volcanic rocks in the successor basins, as discussed previously.

A new age of gold mineralization in the Wawa-Abitibi terrane is represented by the Coté deposit south of Timmins, wherein gold mineralization occurs in a brecciated phase of a granitoid intrusion adjacent to a strike-slip fault just east of the Swayze greenstone belt (Katz et al. 2015). The mineralization is in the Chester granitoid complex, which lies along the interface between the Ramsey-Algoma batholith to the south and the Kenogamissi Batholith to the north. The mineralization consists of orogenic-style mineralization hosted by an intrusion-related magmatic hydrothermal breccia. Significantly, the mineralization is dated at $2737 \pm 8 \mathrm{Ma}$ by Re-Os isotopic dating, in contrast with the ca. 2680-2670 Ma age for most Abitibi gold mineralization (Ayer et al. 1999).

Structural overprinting relationships and the spatial association of lode gold deposits with successor basins and their major strike-slip structures indicate that the lode gold style of mineralization occurs late in greenstone belt evolution. The association of gold mineralization with silicification, Fe-carbonate alteration and elevated LILE provides evidence that the hydrothermal system associated with the deposits circulated through the mid-to-deep crust (Goldfarb et al. 2005). Goleby et al. (2004) have shown that a relationship exists between gold mineralization in the Yilgarn craton and anticlinoria associated with subjacent granitoid rocks, and more importantly, with fault systems extending from the base of the crust through to the mineralized units of the greenstone belt.

\section{Cu-Ni-PGE and Cr Mineralization}

Copper-Ni-PGE mineralization within granite-greenstone terranes occurs in: 1) concordant sills; 2) layered gabbroanorthosite complexes; and 3) komatiitic volcanic units and coeval plutons. In the Superior Province, concordant sills include the Katimiagamak sills in the Wabigoon Subprovince (Davis and Edwards 1986), and layered gabbro-anorthosite bodies include Big Trout Lake in the North Caribou terrane (Whittaker 1986), the Bad Vermilion anorthosite in the Wabigoon subprovince (Ashwal et al. 1983), and the Weese Lake gabbro-anorthosite (Thurston and Carter 1970). PGE mineralization at Lac des Iles in the Marmion terrane is associated with late hydrothermal alteration in the so-called Roby zone (Sutcliffe et al. 1989). $\mathrm{Fe}-\mathrm{Ti}-\mathrm{V}$ mineralization is present in some layered mafic intrusions of the Abitibi greenstone belt, such as the Dore Lake complex in Chibougamau and the Bell River complex in Matagami (Allard 1976; Daigneault and Allard 1990; Taner et al. 2000).

Because of their economic importance, synvolcanic komatiite-tholeiite sequences and their related intrusions are better known. They account for about $25 \%$ of the world nickel resource for deposits grading $>0.8 \% \mathrm{Ni}$ (Lesher 1989). These deposits are located close to the basal contact of individual komatiitic flows and consist of massive and brecciated sulphides toward the base of flows, and matrix-textured and 
disseminated sulphides throughout the flows. In general, this type of mineralization requires a sulphur-undersaturated magma, which becomes sulphur-saturated by assimilation of sulphur-rich rock types enroute to eruption. The massive style of mineralization reflects late assimilation, whereas the more disseminated mineralization reflects slightly earlier assimilation of sulphur. This style of mineralization is found in the Yilgarn craton at Kambalda, where the komatiites consist of thin, extensive sheet flows and thicker, channelized flows (Perring et al. 1994; Hill et al. 1994). The channelized flows may be up to $15 \mathrm{~km}$ long and $100 \mathrm{~m}$ thick; mineralization is concentrated at the base of flows in masses up to $3 \mathrm{~km}$ long and $5 \mathrm{~m}$ thick. Similar mineralization is found in komatiites of the Tisdale and Kidd-Munro assemblages of the Abitibi greenstone belt (Fyon et al. 1992; Ayer et al. 2002a) and in the Zimbabwe craton (Prendergast and Wingate 2013).

Synvolcanic sills and intrusions of broadly komatiitic affinity also host $\mathrm{Cu}-\mathrm{Ni}-\mathrm{PGE}$ and $\mathrm{Cr}$ mineralization, e.g.

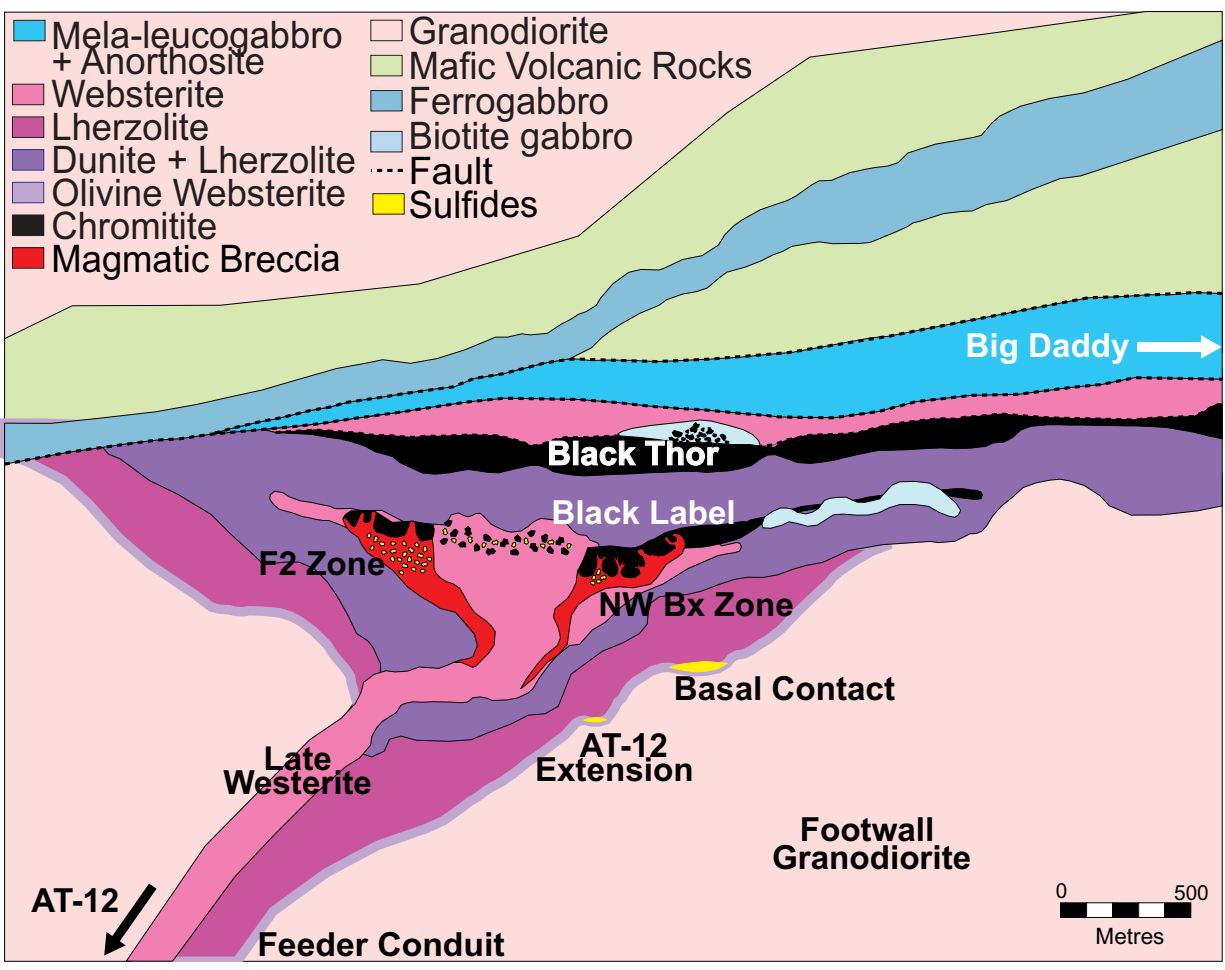

Figure 26. Schematic section of the Black Thor intrusion and associated chromite mineralization in the Ring of Fire area of the North Caribou terrane (after Carson et al. 2013).

the Bird River Sill in the Winnipeg River subprovince (formerly the Bird River subprovince; Scoates and Scoates 2013), the Shebandowan intrusion in the Wabigoon subprovince (Morin 1973), the Big Trout Lake intrusion in the North Caribou terrane (Whittaker 1986), the Kemi intrusion in the Baltic shield (Tormanen and Karinen 2011), and sills related to the Bulawayan Group komatiites (Prendergast and Wingate 2013). Largely post-tectonic intrusions also host $\mathrm{Cu}-\mathrm{Ni}-\mathrm{PGE}$ mineralization in the Superior Province, e.g. Lac des Iles (Sutcliffe et al. 1989).

High Cr, low-MgO (18-24\%) komatiitic magmas may contain a distinct type of chromite mineralization that differs from the classic stratiform and podiform styles. This type occurs in the Baltic shield, Zimbabwe, Brazil and India as well as in the so-called 'Ring of Fire' intrusions in the eastern part of the North Caribou Terrane (Mungall et al. 2010; Carson et al. 2013). The Black Thor intrusive complex in the North Caribou terrane consists of lower and middle ultramafic zones and an upper ultramafic to mafic zone. The mineralization occurs mainly in the middle ultramafic zone as chromite-rich layers interstratified with dunite and peridotite. The deposit contains about $102 \mathrm{M}$ tonnes, has an aggregate thickness of up to 100 $\mathrm{m}$, and a strike length of $3 \mathrm{~km}$ within a relatively small intrusion (Carson et al. 2013; Fig. 26). The thickness and lateral extent of the chromite mineralization mitigates against in situ fractionation such as is observed in a layered intrusion. Instead, Carson et al. (2013) appeal to deposition of the large volumes of chromite in a conduit feeding superjacent komatiite-associated magmatism. Similar ages of mafic and ultramafic intrusions across the Superior Province (from the Bird River area, through the North Caribou terrane to the La Grande and Eastmain domains in Québec) suggest that mafic-ultramafic intrusions in these areas may constitute a distinct $\mathrm{Cr}-\mathrm{Ni}-\mathrm{Cu}-$
PGE-V metallotect 'fundamentally different' from the rest of the Superior Province (Houlé et al. 2012). Such a metallotect crossing many terrane boundaries late in Superior Province history implies a distinct, late event such as plume magmatism or crustal delamination.

Of tectonic importance is the observation of shear-bounded ultramafic intrusions along the interface between the Wabigoon subprovince and the Quetico metasedimentary subprovince to the south, which may indicate tectonic emplacement (Pettigrew and Hattori 2006). In areas removed from greenstone belts, mineralized, relatively small mafic to ultramafic intrusions occur among granitoid units. Given their limited importance, they are not discussed further.

\section{Pegmatite-Hosted Rare Metal Deposits}

Pegmatites and associated rare metal deposits occur within granitoid batholiths or as dikes in the country rock. The pegmatites originate by initial undercooling of granitoid magma to produce the outer zones of the pegmatites, followed by crystallization of very coarse-grained interiors rich in unusual minerals produced by 'constitutional zone refining.' This leads to build-up of fluxing components in a boundary layer, which advances within the pegmatite (London and Morgan 2012). Most Archean pegmatites occur within or proximal to peraluminous or S-type granites (Breaks and Moore 1992; Fyon et al. 1992; Stone 2005), which develop relatively late in the evolution of granitoid rocks in granite-greenstone terranes; they occur as linear plutons proximal to major transcurrent structures, and as batholiths within granite-greenstone terranes and sedimentary subprovinces. Examples of pegmatite-associated mineralization within the Superior Province include: 1) Li and $\mathrm{Be}$ occurrences in pegmatites located along a late structure crosscutting the central part of the North Caribou terrane 
(Stone 1998); 2) pegmatites associated with peraluminous granites in the Abitibi greenstone belt; and 3) pegmatites along the Winnipeg River-Wabigoon subprovince boundary (Fyon et al. 1992). Similar peraluminous granite-associated deposits are known in the Yilgarn craton (Flint 2010) and on other Archean cratons.

\section{ARCHEAN VS. PROTEROZOIC GREENSTONE BELTS}

\section{Introduction}

This article has emphasized Archean greenstone belts, but when we consider a broad definition of greenstone belts as Precambrian belts of low grade, largely volcanic rocks surrounded by granitoid batholiths (e.g. Hunter and Stowe 1997), many Proterozoic orogens have regions that fulfill the definition. Examples include the Trans-Hudson orogen (Gibson et al. 2011) and the multitude of Proterozoic orogens of Africa (Allibone et al. 2002). The major differences between Archean and Proterozoic greenstone belts are summarized below.

\section{Rock Types}

Conventional wisdom has it that Proterozoic greenstone belts lack komatiites. However, the greenstone belts of West Africa (Abouchami et al. 1990) do contain komatiites. The inference is that, although there was a global mantle overturn event at approximately 2.5 Ga (Van Kranendonk 2012), komatiite generation continued for some time after. Comparisons of basalt compositions show that Proterozoic basalts do not display the high Fe content of Archean basalts (Francis et al. 1999).

Mapping in Paleoproterozoic orogens such as the TransHudson orogen (Lucas et al. 1996), the Cape Smith belt (Lesher 2007), and the Fennoscandian shield (Gaál and Gorbatschev 1987) reveals the presence of oceanic floor and oceanic plateau basalts and ophiolites (Galley et al. 2007b). In contrast, there have been contrasting claims about whether or not Archean ocean floor rocks are preserved (Martin et al. 1993; Bickle et al. 1994; Kusky 1998; Kusky et al. 2001). This issue will be discussed more extensively in a subsequent section.

The abundance of TTGs decreased with time and they become lower in Al (Martin 1987); granitoid magmatism in general becomes more potassic in the Proterozoic (Fumerton et al. 1984). Successor basins developed in Proterozoic greenstone belts are similar to those in Archean greenstone belts; for example, they contain clast populations demonstrating granite unroofing (Ansdell et al. 1999).

\section{Structural Style}

In contrast to the dome-and-keel structural style of Archean greenstone belts, individual lithotectonic assemblages in Proterozoic greenstone belts are thrust-bounded packages (Lucas et al. 1996). When Proterozoic orogens as a whole are considered, they vary from clearly accretionary systems to abnormally thick crustal sections related to accretion (Korja et al. 2006).

\section{ARCHEAN TECTONIC MODELS}

\section{General Considerations}

The tectonic processes that produced the unusual rock types and structural style of Archean greenstone belts are important in developing a full understanding of the genesis of Archean granite-greenstone terranes. Identification of the processes involved centres upon the presence or absence of horizontal processes, i.e. Archean plate tectonics vs. vertical processes such as granitoid diapirism and convective overturn. If greenstone belts originate by completely autochthonous processes, this would tend to minimize the importance of horizontal tectonics. If, on the other hand, greenstone belts are allochthonous, complete with fold and thrust belts, metamorphic core complexes, ophiolites, blueschists, etc., then Archean tectonic processes should be little different from those observed in younger orogens. Like most geological problems, there are advocates on both sides of the issue; for example, Hamilton (1998), Stern (2005), and Bédard et al. (2013) favour the autochthonous model, whereas Langford and Morin (1976), Polat et al. (1998), Hollings and Kerrich (1999), and Percival et al. (2004) argue for the allochthonous model. This discussion will review the evidence for both hypotheses.

\section{Plate Tectonic Origin for Granite-Greenstone Terranes}

The plate tectonic model for the modern Earth is characterized by the presence of seafloor spreading, subduction (including its related distinctive magmatism), and continental drift. The operation of the model in the Archean should result in the preservation of rocks and primary structures representing distinct geodynamic settings: ocean floor, island arcs, continental arcs, passive margins, subduction-related mélanges, and metamorphic belts. Langford and Morin (1976) proposed a plate tectonic origin for the Superior Province. They noted the fundamentally different character of granite-greenstone terranes $v s$. sedimentary subprovinces in the northwestern part of the Superior Province in terms of rock types, metallogeny, stratigraphy and radiometric ages. The hypothesis was supported by a limited number of U-Pb zircon ages showing that the northern part of the Superior Province is older than the greenstone belts to the south (Krogh and Davis 1971). More recent syntheses of Superior Province geology (Card 1990; Williams et al. 1992) have fleshed out the concepts. Percival and coworkers (Percival et al. 2004, 2006; Percival and Helmstaedt 2006) established over 20 domains, terranes, subprovinces and superterranes in the Superior Province. These authors classify the various tectonic blocks as continental fragments (e.g. North Caribou, Marmion, and Winnipeg River terranes) separated by volcanic-rich oceanic domains (e.g. the Wawa-Abitibi and Wabigoon terranes, and Oxford-Stull domain) and orogenic flysch belts (e.g. the English River, Quetico, and Ashuanipi belts).

Evidence favouring the plate tectonic hypothesis in the Superior Province includes: 1) the long, linear nature of the various tectonic blocks; 2) an orderly southward-younging of the ages of volcanism, plutonism, and shear zones (Fig. 27) bounding major tectonic blocks; and 3) a crustal structure observed in reflection seismic images that is consistent with accretionary tectonics (Calvert et al. 1995; Calvert and Ludden 1999; White et al. 2003; Percival et al. 2004a; Percival and Helmstaedt 2006). The plate tectonic hypothesis calls for a ca. $2720 \mathrm{Ma}$ amalgamation of the Hudson Bay terrane (or Northern Superior superterrane) with the North Caribou terrane, followed by the Uchian orogeny in which the North Caribou, English River, and Winnipeg River terranes are accreted at about $2700 \mathrm{Ma}$, and finally the Shebandowanian orogeny in 


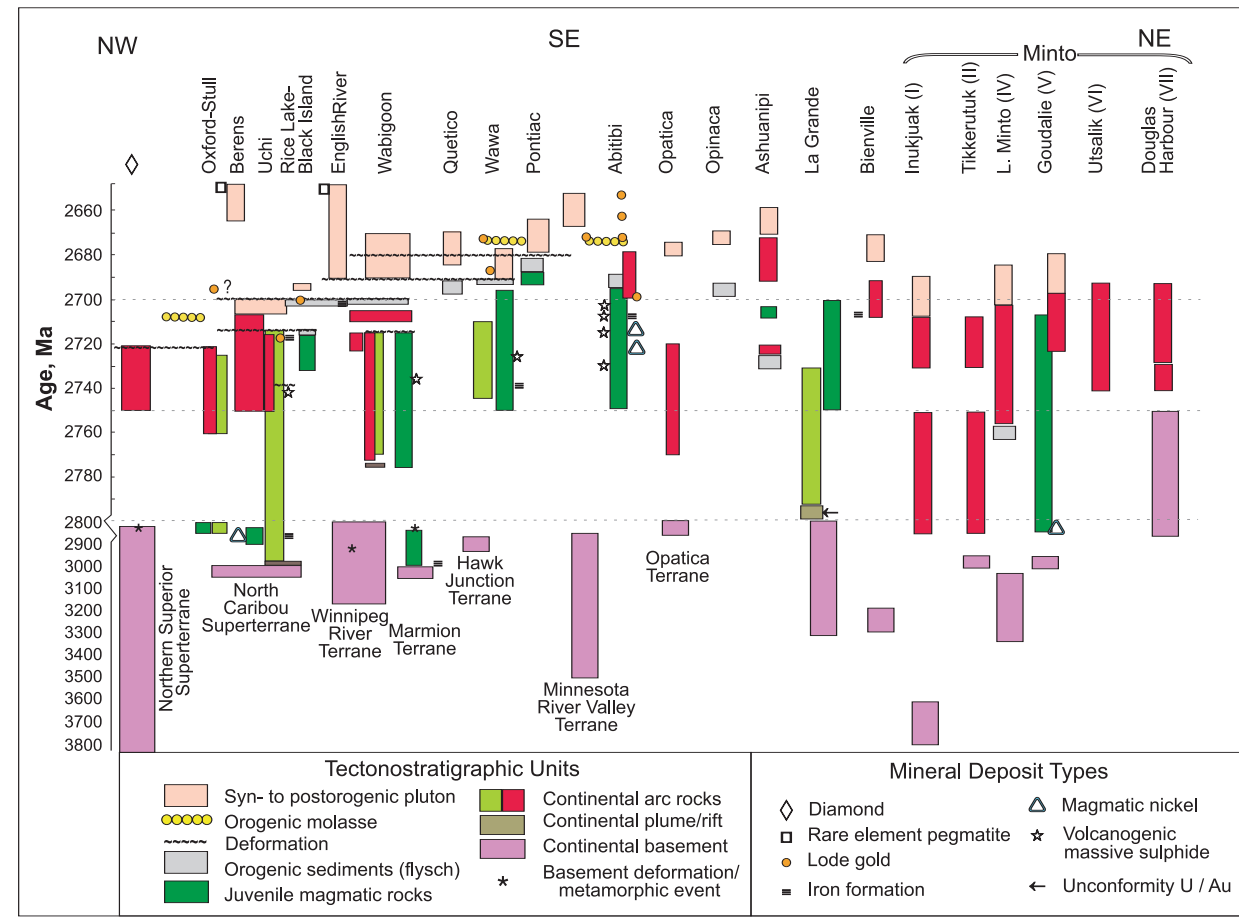

Figure 27. Time-space chart for the Superior Province by Percival (2007).

which the composite Superior superterrane collides with the Wawa-Abitibi terrane at about $2690 \mathrm{Ma}$ (Fig. 1).

Another major line of evidence for the plate tectonic hypothesis is the presence in greenstone belts of relatively unusual, geochemically-defined rock types having linkages to plate tectonic processes in younger orogens, as discussed previously. The most extensive research on these unusual rocks has been done in the Superior Province. They include boninites (Kerrich et al. 1998) in the komatiite-tholeiite geochemical association, and adakites, high-Mg andesites, and $\mathrm{Nb}-$ enriched basalts in the bimodal geochemical association. The adakites and related rocks are found in volcanic units (e.g. Hollings and Kerrich 2000; Wyman et al. 2000; Polat and Kerrich 2001; Boily and Dion 2002), syn- to late-tectonic batholiths (Feng and Kerrich 1992), and in post-tectonic diorites/sanukitoids (Smithies and Champion 2000). These unusual rock types are also documented in the Yilgarn (Angerer et al. 2013), Pilbara (Smithies 2002), Baltic (Shchipansky et al. 2004), Dharwar (Manikyamba et al. 2005; Naqvi et al. 2006; Naqvi 2008), and Kaapvaal (Wilson 2002) cratons.

Many authors point to reflection seismic images as evidence for the operation of plate tectonics in the development of the Superior Province (Percival et al. 2004, and references therein). The presence of fossil subduction zones in reflection seismic profiles has been discussed in a previous section. However, similar structures beneath the Yilgarn craton are interpreted to indicate delamination at the base of the crust (Goleby et al. 2006).

\section{The 'Metamorphic Core Complex' Model}

Alpine-style thrusting allied with extension can produce socalled 'metamorphic core complexes.' Such a model has been proposed for the Superior (Sawyer and Barnes 1994) and Pilbara (Bickle et al. 1980; Zegers et al. 1996; Blewett 2002) cratons. This style of tectonics requires extensive normal faulting and extension such that domical zones of high metamorphic grade rocks (centred on granitic batholiths) form the structures known as metamorphic core complexes. The advent of widespread geochronology in granite-greenstone terranes has ruled out the extensive duplication of strata expected with such a model in either of these cratons, as seen in more recent descriptions (Van Kranendonk et al. 2007a; Thurston et al. 2008).

\section{The 'Mantle Wind' Model}

The continued northward motion of the Indian microcontinent leading to collision with Eurasia has taken place over ca. 50 m.y. without the presence of a plate boundary driving force. Alvarez (2010) advanced the concept of 'basal traction,' or more colloquially the 'mantle wind,' as the driving force for this movement. This mechanism is the basis for an alternative tectonic model for the Archean (Bédard et al. 2013), as summarized in the following paragraphs.

The model requires the development of cratonic 'roots' or 'keels' that extend to or beyond the lithosphere-asthenosphere boundary. These keels obstruct upper mantle flow, which deflects around the keels and also has the effect of moving them. This process provides the force to move continental blocks, resulting in the accretion of microcontinental fragments to make cratons. The individual microcontinental blocks represent oceanic plateaux in which komatiitic to tholeiitic greenstones develop, and the increasing thickness of these plateaux would bring basaltic material down to depths required to produce T'TGs and TTG-related felsic volcanic rocks.

However, the oceanic plateaux suggested in the Bédard et al. (2013) model (Fig. 28) probably differ from modern equivalents. As noted by Kamber (2015), the consistent upward younging of greenstone stratigraphy described above for most greenstone belts is the essence of a volcanic plateau. Kamber (2010) also noted the existence in the Archean of a second type of landmass, based on the REE chemistry of marine chemical sediments and their Sr- and Nd-isotopic systematics. Any postulated Archean volcanic plateau would differ from modern oceanic plateaux in terms of: 1) the presence of synvolcanic granitoid rocks; 2) the prevailing extensive hydration of Archean basalts in greenstone belts; and 3) the presence of thick cratonic mantle keels (Kamber 2015). The thickness and higher temperature of Archean plumes would have permitted the vertical growth of thick volcanic plateaux.

In the absence of plate tectonics, how are the overprinting structural fabrics and shortening in Archean orogens explained? If the Archean lacked subduction zones, then a global oceanic spreading ridge system cannot have existed, leaving only oceanic plateau crust - broadly comparable to the mafic units of greenstone belts. In this model, contractional structures and accreted terranes would develop at the leading edge of the craton and strike-slip structures at the sides. 


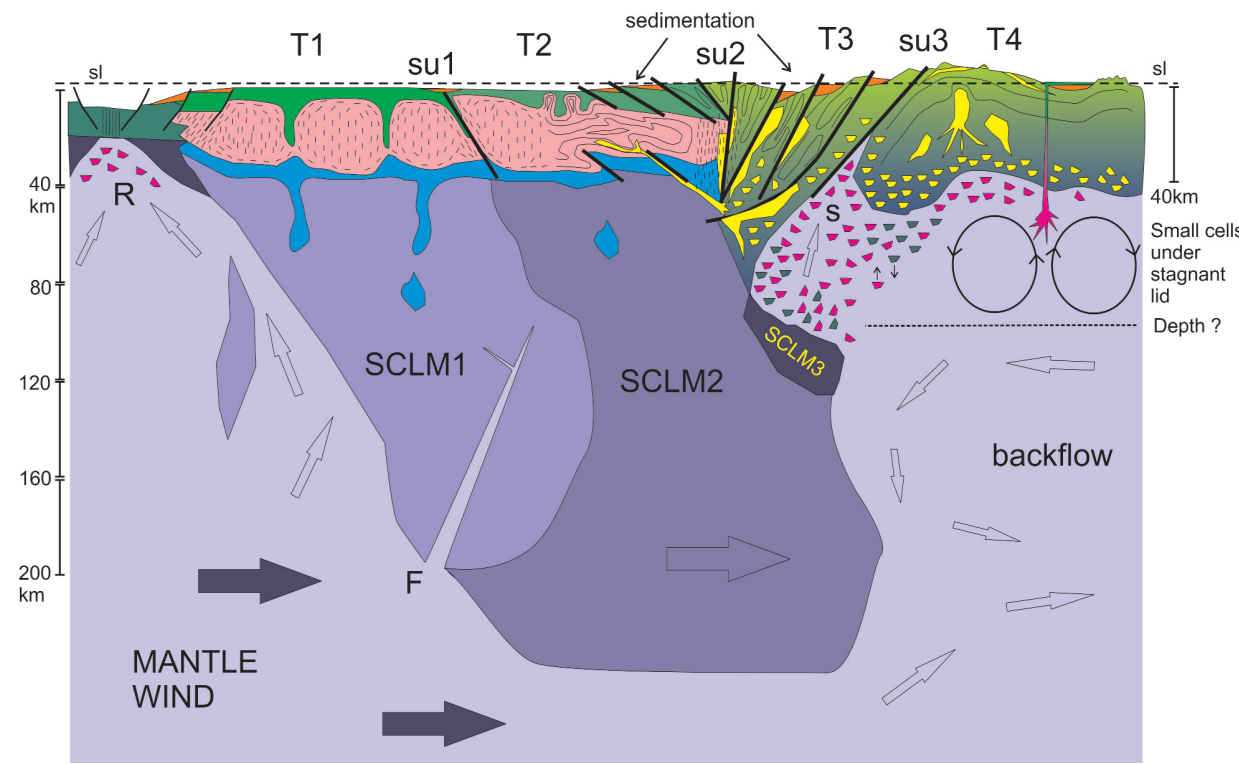

Figure 28. Bédard et al. (2013) mantle wind model. In this model, a composite older terrane consists of two terranes (T1 and T2) each with subjacent sub-continental lithospheric mantle keels (SCLM 1 and 2) separated by a soft-docking suture. Terrane 1 is characterized by vertical fabrics in the T'TG dominated mid-crust, whereas T2, originally similar, has been overprinted during accretion to T1 and T3. Terranes T3 and T4 are simatic oceanic plateau crust. Mature sedimentary rocks develop in localized ensialic basins or at craton margins. Terrane 4 is building up a thick plateau through underplating and eruption of basalt (red) and is underlain by small convection cells. Anatexis generated juvenile TTGs (yellow) are produced and at this stage, dome and keel structures also develop. SU1 is a soft-docking suture between T1 and T2. SU2 is a suture separating T2 and T3 with much flattening in the proximal lower crust. SU3 separates T3 and T4 and has thinner crust underlain by hot mantle.

\section{Ophiolites}

Ophiolites consist of two types: 1) Cordilleran ophiolites that are scraped off downgoing oceanic crust; and 2) Tethyan ophiolites obducted onto continents by failed continental subduction (Sylvester et al. 1997). The presence of distinctive sheeted dike arrays within ophiolites is a function of the balance between spreading rate and magmatism (Robinson et al. 2009). Although Archean ophiolites have been proposed (Helmstaedt et al. 1986; de Wit et al. 1987; Kusky 1998; Kusky et al. 2001; Dilek and Polat 2008), nowhere is a full ophiolite section of Archean age preserved. In a putative example of Archean oceanic crust reported by Kusky and Kidd (1992), Bickle et al. (1994) found basal unconformities rather than tectonic contacts, xenocrystic zircons indicating interaction with older crust, isotopic and geochemical evidence of crustal contamination, and intrusive relationships between older basement and the internal stratigraphy of the purported ophiolite. If Archean oceanic crust were thicker than modern oceanic crust (Sleep and Windley 1982; Hoffman and Ranalli 1988), deeper crust characterized by distinctive ophiolite

\section{DISCUSSION}

\section{Introduction}

Having described the essential elements of the plate tectonic model for Archean granite-greenstone terranes and the major competing 'mantle wind' model, a critical examination of the relationship of features of granite-greenstone terranes to one or the other tectonic model is useful. In contemplating whether plate tectonics operated in the Archean, it must be remembered that the dominant force in the plate tectonic paradigm is the sinking of cold, dense lithosphere. Therefore, plate tectonics requires a lithosphere that is sufficiently cool to allow it to sink into the asthenosphere (Stern 2008).

\section{Missing Plate Tectonic Indicators}

Numerous authors have noted the nearly complete absence of ophiolites, Atlantic-style passive margins, overprinting foldand-thrust belts, paired metamorphic belts, ultra-high-pressure (UHP) and ultra-high-temperature (UHT) metamorphic assemblages, and subduction zone mélanges in Archean granite-greenstone terranes (Kröner 1991; Chardon et al. 1996; Hamilton 1998, 2007; Bleeker 2002; McCall 2003; Stern 2005, 2008; Brown 2006, 2007). Subsequent investigations (Bédard et al. 2013) have noted the absence in greenstone belts of both the extensive talus and lahar aprons surrounding 'arc' sequences (perhaps a preservation problem?), and the orogenic andesites typical of continental and island arc systems. Archean granite-greenstone terranes also lack the high proportion of mudstone found in modern orogens (Thurston 2012). features such as sheeted dikes may well have been subducted (Condie and Benn 2006). The proposed ophiolite in the Kam Group of the Yellowstone greenstone belt in the Slave Province (Helmstaedt et al. 1986) has been disproved using trace element geochemistry and $\mathrm{Nd}$ isotopic data (Cousens 2000). Similarly, the proposed 2.5 Ga Dongwanzi ophiolite (Kusky et al. 2001) has subsequently been questioned (Zhai et al. 2002).

\section{Atlantic-Style Passive Margins}

Atlantic-style passive margins featuring widespread units of shallow-water carbonate and siliciclastic rocks do not exist in Archean granite-greenstone terranes. In the La Grande subprovince, lateral transitions over a distance of $5-8 \mathrm{~km}$ have been observed from shallow-water quartz arenites displaying cross-stratification and mud drapes, to submarine fans containing sheet sandstones (Goutier 2006). Sedimentary carbonate units in the Archean are rare and of limited lateral extent (Ojakangas 1985). However, Condie and Benn (2006) point to sequences such as the Moodies Supergroup of South Africa (Lowe et al. 1999) as possible analogues of Atlantic margins.

\section{Deep-Water Sedimentary Rocks}

Metasedimentary rocks, especially mudrocks, make up only a very small proportion of volcanic successions in Archean greenstone belts of most cratons, including the Superior Province (Williams et al. 1992), the Yilgarn craton (Myers and Swager 1997), the Pilbara craton (Barley 1997) and the West African craton (Attoh and Ekwueme 1997). Although wacke-pelite sequences are rare in greenstones of the Superior and Kaapvaal cratons, they do make up much of the sedi- 
mentary subprovinces of the Superior craton (Williams et al. 1992) and the Limpopo belt of the Kaapvaal craton (Eglington and Armstrong 2004). In contrast, the Slave craton has areally extensive sediments overlying the greenstone belts (Bleeker and Hall 2007). In modern orogens, deep-water sedimentary rocks consist of $\sim 70 \%$ mudstones (Aplin and Macquaker 2011).

\section{Fold and Thrust Belts}

There are numerous descriptions of thrusting within greenstone belts on most cratons (de Wit et al. 1987; Devaney and Williams 1989b; Van Kranendonk et al. 2002; Bleeker 2012; Furnes et al. 2013). The crucial question is whether the thrusting is local or larger in scale. Greenstone belts in the Superior craton (Williams et al. 1992), the Pilbara craton (Van Kranendonk et al. 2004), and in Zimbabwe (Prendergast 2004), as typical examples, feature upward-facing, upward-younging stratigraphy, and no major thrust-based stratigraphic duplication or long-distance tectonic transport by thrusts. Reflection seismic images (Goleby et al. 2004; Snyder et al. 2008) show that there is no kilometrescale thrust transport of greenstone sequences, in contrast to the structural style of Phanerozoic accretionary orogens (Percival et al. 2004).

\section{Blueschists, Ultra-High-Pressure Rocks, and Paired Metamorphic Belts}

Blueschist metamorphic rocks typical of subduction zones are not known in the Archean, probably because of higher thermal gradients (Hamilton 1998) and the difficulty of rapid exhumation (Ernst and Liou 1999). Likewise, ultra-high-pressure rocks of Archean age are rare (Brown 2007; Stern 2008), although they are found at Gridino on the White Sea in the Karelian craton (Perchuk and Morgunova 2014). Paired metamorphic belts consist of a trench-proximal, high pressure, low temperature belt succeeded inland by a low pressure, high temperature belt. Such pairings, typical of subduction settings (Miyashiro 1973), are not found in the Archean, again a likely function of the Archean thermal regime (Komiya et al. 2002).

\section{Structural Style}

The dome-and-keel structural style of Archean greenstone belts is unique and not repeated in subsequent earth history (Bédard et al. 2013). Although there is a southward younging of plutonism, volcanism, and shear zones in the Superior Province, each major terrane has a unique, specific assemblage of rock types and event ages (Percival 2007). These relationships have been interpreted in terms of a plate tectonic scenario (Percival 2007), but it must be borne in mind that these relationships are also consistent with simple lateral transport of individual terranes.

\section{Autochthonous vs. Allochthonous Greenstone Belts}

If greenstone belts are autochthonous, this would tend to support a non-plate tectonic origin; however, it is still possible to consider autochthonous greenstones to represent some sort of continental arc setting. Listed below are characteristics of greenstones supporting an autochthonous origin.

1) Diking relationships in the Abitibi greenstone belt (Ayer et al. 2005) and the Confederation Lake greenstone belt of the North Caribou terrane (Rogers et al. 2000) show that dikes cutting older units are feeders to overlying volcanic units (Fig. 29); thus, older units in two major Superior Province greenstone belts were present when younger units were deposited. This may represent a limited dataset, but it is in two critical areas for interpretation of Archean tectonics in the Superior Province: the North Caribou superterrane (see also Parks et al. 2006) respecting the superterrane as a whole, and the Abitibi greenstone belt.

2) Isotopic inheritance is seen in recent U-Pb zircon age determinations in about $15 \%$ of samples from the Abitibi greenstone belt. The xenocrystic zircon grains are found in younger greenstone units and represent the ages of underlying volcanic units (Ayer et al. 2005). Similar inheritance patterns are seen in the Marmion terrane (Buse et al. 2010) and in the North Caribou terrane (Parks et al. 2006) of the Superior Province. In the Murchison domain of the Yilgarn craton (Van Kranendonk et al. 2013), 39 of $117 \mathrm{U}-\mathrm{Pb}$ zircon ages (mainly of greenstone belt units) show xenocrystic zircons. Extensive isotopic inheritance is described in the Pilbara terrane (Van Kranendonk et al. 2007a). However, the Abitibi greenstone belt units are largely juvenile and gener- 
ated in contemporaneous depleted mantle (Corfu and Noble 1992; Carignan et al. 1993; Vervoort et al. 1994). Nevertheless, Hf isotope data show that the western edge of the Abitibi greenstone belt was underlain by $2.8-2.9$ Ga crust (Ketchum et al. 2008).

3) Contamination of Archean basalts, based on negative $\mathrm{Ti}, \mathrm{Nb}$ and $\mathrm{Ta}$ anomalies, is postulated to represent contamination of basaltic magmas through contact with granitoid rocks (Thurston 2002, and references therein), although these features can also be explained by magma origins in subduction systems (Polat et al. 1998; Hollings and Kerrich 2000) or by melting of over-thickened mafic crust (Hoffmann et al. 2011).

4) Basal unconformities between basement and greenstone belt units imply either a continental arc setting for a given belt, or autochthonous development (Thurston 2002). Basal unconformities are widespread in the North Caribou terrane (Thurston et al. 1991), at Steeprock in the Marmion terrane of the Superior Province (Wilks and Nisbet 1988), in the Slave craton (Bleeker 2002), and in the Belingwe greenstone belt of Zimbabwe (Bickle et al. 1994). Subtle cryptic unconformities can be marked by leaching of underlying greenstones (Thurston and Kozhevnikov 2000).

5) Stratigraphic patterns: The volcanic units in most major greenstone belts worldwide display upwardfacing sequences, along with the younging of volcanic units away from granitoid bodies, indicating that the batholiths and surrounding volcanic rocks represent a series of crustal sections (Van Kranendonk et al. 2002; Thurston et al. 2008). In the larger greenstone belts, some fundamental conundrums exist. For example, the seven volcanic assemblages of the Abitibi greenstone belt (Thurston et al. 2008) represent a total stratigraphic thickness of at least $45 \mathrm{~km}$. However, the greenstone belt is at subgreenschist to greenschist grade (Easton 2000), which is difficult to reconcile with an average geothermal gradient of $25-30^{\circ} \mathrm{C} / \mathrm{km}$. Have large greenstone belts (Fig. 2) undergone thrust-based condensation of stratigraphy? Is there some sort of volcanism-induced subsidence (Hargraves 1976), or is the stratigraphic thickness a function of onlapping stratigraphic lenses? In contrast to Phanerozoic orogens, most greenstone belts do not display evidence for large-scale horizontal tectonic transport. For example, in the Abitibi greenstone belt, Thurston et al. (2008) note a lack of evidence for large-scale thrusting, whereas in detailed seismic sections (Snyder et al. 2008), there are few out-of-sequence volcanic units (Ayer et al. 2005), and detailed structural studies (Benn and Peschler 2005) all indicate no large-scale thrusting. The stratigraphic map of the Abitibi greenstone belt (Thurston et al. 2008; Fig. 18) demonstrates off-lapping stratigraphic geometry. Similar patterns of upward-facing, upwardyounging stratigraphy are seen in the North Caribou terrane (Thurston et al. 1991; Sanborn-Barrie et al. 2001), the Wabigoon subprovince (Sanborn-Barrie and Skulski 2006), and the Pilbara (Van Kranendonk et al. 2007a), Yilgarn (Van Kranendonk et al. 2013), and Zimbabwe (Bickle et al. 1994) cratons.

The stratigraphy of plume-related units in the Abitibi greenstone belt shows some interesting patterns involving potential structural controls. There are basically three plume events in the Abitibi greenstone belt: 1) the 2723-2720 Ma Stoughton-Roquemaure episode; 2) the 2719-2711 Ma Kidd-Munro episode (including the 2717-2714 Ma LaMotte-Vassan Group in Québec); and 3) the 2710-2704 Ma episode (Tisdale in Ontario and Jacola in Québec), collectively related to a single plume in which magma separation occurred at increasingly shallower depths (Sproule et al. 2002; Dostal and Mueller 2013). The komatiites occur along two crustalscale fault zones, suggesting that the plume either created or followed these zones of weakness. Interdigitation of compositionally different komatiites and tholeiites in small-volume $\left(1-10 \mathrm{~km}^{3}\right)$ flows suggests a compositionally heterogeneous plume; selective tapping of various plume zones would then explain this style of compositional variation. Dostal and Mueller (2013) compare this situation to the Yellowstone hotspot, which developed over ca. 17 m.y. and had a diameter of about $300 \mathrm{~km}$.

Archean greenstone belts present a paradox, in that rocks of the komatiite-tholeiite association are of plume derivation and make up $80-90 \%$ of many greenstone belts (Ayer et al. 2005; Van Kranendonk et al. 2007a; Thurston et al. 2008; Barnes and Van Kranendonk 2014), whereas interbedded calcalkaline units have been interpreted to represent convergent margin processes. Plume-arc interaction has been invoked (Kerrich et al. 1998; Wyman et al. 2002), but a scale problem and a mechanical problem both emerge when one observes that, in the Yilgarn (Barnes and Van Kranendonk 2014), extensive plume-related komatiites and tholeiites are accompanied by minor accumulations of calc-alkaline andesite to dacite/rhyolite. In the Abitibi greenstone belt there is a fourfold repetition of this pattern (Ayer et al. 2002b), requiring an appeal to multiple episodes of arc-plume interaction (Bédard 2013; Bédard et al. 2013). Wyman and Kerrich (2009) respond by proposing a subduction zone along the entire south margin of the Superior Province.

\section{Evidence for Modern Plate Tectonic Interpretations}

The term, 'oceanic domains,' is controversial. The 'oceanic domains' of Percival (2007) should display no isotopic inheritance; however, it must be borne in mind that an age difference between two units of at least $150 \mathrm{~m} . \mathrm{y}$. is necessary for discernible evidence of inheritance to be apparent in the $\mathrm{Sm}-\mathrm{Nd}$ and $\mathrm{Lu}-\mathrm{Hf}$ systems (Larbi et al. 1999). Second, the process of searching for datable zircon grains in a geochronological lab involves a general process of: 1) ignoring high-U grains, in that they are strongly discordant; and 2) concentration on one or two zircon populations in order to obtain a crystallization age. Thus, $20^{\text {th }}$ century U-Pb zircon geochronology rarely found zircon xenocrysts. With the advent of single-grain dating, researchers have found xenocrystic zircons in multiple 'oceanic domains,' including modern oceanic crust (Pilot et al. 1998; Tapster et al. 2014) and in Archean settings such as the Abitibi 
greenstone belt (Ayer et al. 2005) and the Marmion terrane (Tomlinson et al. 2003; Buse et al. 2010). Similar patterns of xenocrystic zircons representing subjacent units are now found in other cratons, such as the East Pilbara (Van Kranendonk 2012) and the Yilgarn (Claoué-Long et al. 1988).

Much of the evidence for any plate tectonic interpretation of granite-greenstone terranes lies in the geochemistry of the volcanic units and the post-TTG granitoid rocks. As described previously, geochemical signatures of 'arcs' are found both in the mafic and the felsic volcanic units within greenstone belts. The geochemical signature of modern arcs consists of: 1) enrichment of LILE ( $\mathrm{Sr}, \mathrm{K}, \mathrm{Rb}, \mathrm{Ba}) v s$. HFSE (Th-Yb), which exhibit MORB-like concentrations. In addition, arc rocks show distinctive negative anomalies for $\mathrm{Ti}, \mathrm{Nb}$ and $\mathrm{Ta}$. However, the stratigraphic/tectonic location of Archean greenstones with the 'arc' signature is critical to their interpretation. 'Arc' rocks in greenstone belts occur mainly in the bimodal geochemical association in both the basaltic basal zones of these sequences and in the isolated felsic eruptive centres (Ayer et al. 2005) and, more rarely, in distinct tectonically-bounded zones of greenstone belts (Lodge et al. 2013).

There is evidence for large-scale tectonic transport of terranes (as distinct from stratigraphic units) in the Superior Province; this is seen in the uniform northward vergence of structures associated with terrane margins (White et al. 2001). In addition, the provenance of sedimentary rocks in the sedimentary subprovinces indicates derivation from terranes on the north margins of, for example, the English River (Breaks 1991; Hrabi and Cruden 2006) and the Quetico (Williams 1991) subprovinces. Inevitably, the margins of cratonic blocks in Archean orogens will demonstrate structural complexity. For example, Kusky and Polat (1999) describe the intercalation, along the south margin of the Wawa-Abitibi terrane, of tholeiitic to calc-alkaline basalts (island arc?) and metasedimentary rocks that are collectively interpreted to represent an accretionary collage. The thrust-telescoped transition along the south margin of the Wabigoon subprovince, from alluvial metasedimentary rocks and back arc basalts, through submarine fan sedimentary rocks and arc basalts, to abyssal wackes and oceanic basalts (Tomlinson et al. 1996), has been interpreted to record plate-related accretion (Devaney and Williams 1989).

\section{Inconsistencies in the Plate Tectonic Model for Archean Greenstone Belts}

In this section, the various inconsistencies in the plate tectonic model for Archean greenstone belts are enumerated, with emphasis on the Superior Province.

\section{Geochemistry and Stratigraphy}

Researchers of the Kerrich school (Kerrich, Wyman, Polat and Hollings) have found small volumes of unusual rock types such as boninites, adakites, Nb-enriched basalts and magnesian andesites within greenstone belts of the Superior Province, as described above. Similar features are found in the Pilbara craton (Smithies 2002; Smithies et al. 2005, 2007). Given the fact that approximately $90 \%$ of greenstone belt stratigraphic sections are plume-derived tholeiites and komatiites, arc-plume interaction (Wyman and Hollings 1998; Wyman and Kerrich 2009) is the conventional explanation for an apparent strati- graphic alternation of plume-derived units and units with an 'arc' signature. However, it is difficult to envision mechanisms for alternating between plumes and arcs on an erratic basis (Maurice et al. 2009; Leclerc et al. 2011); for example, a fourfold repetition of such a process is required, according to this model, to explain the stratigraphy of the Abitibi greenstone belt, although one can also appeal to the slab window hypothesis (Thorkelson 1996). It must be borne in mind that a subduction-related origin, proposed by some authors for the adakites, magnesian andesites and $\mathrm{Nb}$-enriched basalts in Superior Province greenstones, can be explained by other processes.

\section{The Andesite Problem}

One of the more intriguing differences between Archean greenstones and modern orogens concerns the lack of andesites in the former. Classical fractional crystallization from basalt to granite should yield more andesites than are seen in greenstone belts (Thurston et al. 1985). Intermediate volcanic rocks in the andesite compositional range are scarce in komatiite-tholeiite geochemical associations of greenstone belts (Ayer et al. 2005) and are somewhat more abundant but still rather scarce in the bimodal geochemical association (Thurston et al. 1985). However, Archean andesites do not approach the nearly $40 \%$ abundance seen in the modern continental arc record and just slightly less in oceanic arcs (Winter 2001, p. 326). Archean andesites generally lack the diagnostic plagioclase and pyroxene phenocrysts of modern andesites (Thurston and Fryer 1983; Ayer et al. 2005). Leclerc et al. (2011) show that andesites in the Chibougamau area of the Abitibi greenstone belt occur as thin packages in a monotonous sequence of tholeiites and komatiites, and suggest that they are a mixing product. Some Archean andesites are products of fractionation from basaltic precursors (Thurston and Fryer 1983), some are produced by contamination of mafic magmas (Szilas et al. 2013; Barnes and Van Kranendonk 2014), and others are produced through what is considered to be an 'arc' petrogenesis (Polat et al. 1998; Polat and Kerrich 2002). The andesites in modern orogens are a product of the mixing of mantle-derived basaltic melts with fused granitoid material in the overlying continental crust (Gill 1981). Many Archean greenstones are either deposited on basement or have older granitoid rocks in the vicinity, indicating that granitoid material was available, if the Phanerozoic andesite petrogenetic model were found applicable to the Archean.

\section{TTG Volumes and Their Production by Subduction- Related Melting}

Archean TTGs make up as much as $90 \%$ of the presently exposed middle crust and deep crust of Archean cratons (Windley and Garde 2009; Bédard et al. 2013). However, Condie (1993) demonstrated, using the composition of Archean metasedimentary rocks, that, on average, Archean continental crust is more mafic than TTGs. Archean TTGs display steep REE patterns, considered by most researchers to be generated by anatexis of basic rocks, leaving behind garnetbearing, feldspar-free residues. To explain the steep REE patterns, these rocks must either be products of small-degree melts, or have garnet in the residue (Martin 1987; Smithies and Champion 2000). Bédard et al. (2013) provide a series of argu- 
ments to demonstrate the difficulty of generating the great volumes of TTGs in middle to deep crust by subduction processes. For example, given the $40 \mathrm{~km}$ thickness of northeastern Superior Province crust and its width of $500 \mathrm{~km}$, some $20,000 \mathrm{~km}^{3}$ of TTG $/ \mathrm{km}$ of strike length must be generated in the 300 m.y. interval from 3.0 to 2.7 Ga. Furthermore, when the $2740-2720 \mathrm{Ma}$ actual range of TTG ages in the northeastern Superior Province is factored in, $10,000 \mathrm{~km}^{3}$ of TTG $/ \mathrm{km}$ of strike length must be generated in a 20 m.y. period. If this is accomplished by $10 \%$ melting of a $10 \mathrm{~km}$ thick slab moving at $1.2 \mathrm{~cm} /$ year, then only $3600 \mathrm{~km}^{3}$ of TTGs are generated in 300 m.y. In short, to generate the observed volume of TTGs in the northeastern Superior Province, six subduction zones operating an order of magnitude faster is required. These calculations assume melting of the entire 10 $\mathrm{km}$ thickness of the oceanic slab, which is also not realistic.

\section{Role for Lateral Accretion?}

Early investigators (Langford and Morin 1976; Card 1990) interpreted the southward younging of the ages of volcanic rocks, granitoid rocks, and terrane-bounding shear zones in the Superior Province in terms of plate tectonic processes. The argument can also be advanced that the southward-younging ages of shear zones, in particular, can be explained by lateral accretion of terranes onto an older $(\sim 3 \mathrm{Ga})$ central nucleus, the North Caribou Terrane, without requiring subduction (Bédard et al. 2013). In fact, the detritus in the sedimentary accumulations on the margins of granite-greenstone terranes (e.g. the English River and Quetico terranes in the Superior Province) are derived from the adjacent granite-greenstone terranes to the north of these metasedimentary subprovinces (Davis 1990, 1993).

\section{Other Models}

The geochemical arguments about rutile retention and production of the observed large volumes of TTGs in granitegreenstone terranes suggest that a serious re-examination of alternatives is required. Bédard et al. (2013) support a so-called 'mantle wind' model involving mantle currents laterally displacing oceanic plateaux. In this model, there would be contractional structures and accreted terranes at the leading edge of cratons, strike-slip and oblique extensional structures at the sides, and major shear zones in the cratonic interiors.

\section{CONCLUSIONS}

\section{Secular Variation}

In the Archean Earth, radioactive heat production was concentrated in the crust, given the greater concentration of $\mathrm{K}, \mathrm{U}$, and $\mathrm{Th}$ in the crust compared to the mantle. With heat production concentrated in the crust, the crust became strong. The temperature of the Archean asthenosphere was not uniform; rather, it was concentrated in mantle plumes (Kamber 2015). The proportion of komatiites was higher, and these rocks were distinctly different from their modern analogues (Arndt et al. 2008). TTGs were more abundant, and the highAl type was more abundant than the low-Al type (Martin 1987; Bradley 2011).

\section{Additional Constraints on Archean Tectonic Regimes}

Condie and Benn (2006) provide an elegant summary of constraints on Archean tectonic regimes that forms the basis for the following analysis. Although the dome-and-keel structural style of Archean greenstone belts is more readily attributed to vertical tectonics (Van Kranendonk et al. 2004), the upright regional-scale folds and transpressive shear zones are more easily explained by rigid lithospheric plates (Choukroune et al. 1997). The large volume of Archean crust produced at $\sim 2.7$ $\mathrm{Ga}$ is not an artefact of preservation, in that it is mirrored by: 1) the abundance of komatiites and changes in shale geochemistry, a proxy for a major change in crustal composition (Taylor and McLennan 1985); and 2) variations in the compositon of sub-continental lithospheric mantle (Griffin et al. 2003). Archean cratons have unusually thick, depleted lithosphere that formed at about the same time as the overlying crust (Begg et al. 2009) and the buoyant oceanic plates beneath the continent, yet Archean eclogitic and granulite xenoliths are not common on Archean cratons (Condie and Benn 2006). Many Archean greenstones contain rocks with 'arc-like' geochemistry, a key indicator of plate tectonics. Plume-derived greenstones form up to $80 \%$ of Archean greenstone belts (Condie and Benn 2006), which is greater than the proportion seen in younger orogenic systems. Paleomagnetic data from the Kaapvaal craton (Layer et al. 1989) and Superior craton (Hale and Lloyd 1989) indicate that there was significant polar wandering in the Archean.

In the face of these factors, how is a definitive conclusion reached with respect to the operative processes in Archean tectonics? The modern style of plate tectonics requires the Earth to have cooled sufficiently to generate decompression melting at mid-ocean ridges, in turn allowing oceanic lithosphere to develop sufficient negative buoyancy after a few tens of millions of years to initiate subduction. A conservative point of view states that unequivocal plate tectonics did not begin until ca. 1.9 Ga (Lucas et al. 1996) or perhaps $1 \mathrm{Ga}$ (Condie et al. 2006; Stern 2008). More moderate points of view (Dhuime et al. 2012; Laurent et al. 2014) would have plate tectonics begin at some point between 3.0 and $2.5 \mathrm{Ga}$. In reality, plate tectonics probably made a few 'false starts' prior to becoming the prevailing system we know today (Silver and Behn 2008).

At this time there are few explanations for the absence of key rock types such as andesites that are indicative of plate tectonics. Although some may not agree with the discussion of TTG generation and volumes of TTGs presented by Bédard et al. (2013), this author prefers to conclude that, while there are geochemical features interpreted as evidence of subduction, the missing rock types are a powerful argument for the 'mantle wind' hypothesis. Modifications of that hypothesis are contained in the work of Kamber (2015).

\section{ACKNOWLEDGEMENTS}

Aspects of this paper have been aided by a recent review of Archean greenstones concentrating largely on the Kaapvaal craton (Anhaeusser 2014) and an interesting review of Precambrian geodynamics (Kamber 2015). This review came about through an invitation from Jarda Dostal, an associate editor of Geoscience Canada. My knowledge of granite-greenstone terranes has benefited from my experience with the Ontario Geological Survey, as well as my subsequent tenure in the Department of Earth Sciences at Laurentian University. At Laurentian, I was aided by NSERC Discovery Grants to pursue various topics centred on greenstone belt geology. This contribution was improved by early reviews from colleagues Harold Gibson and Matt Leybourne, and by the work of journal referees Pierre-Simon Ross and 
Pete Hollings. Drafting was done by Lorraine Dupuis, Sara-Jane McIlraith and Julie Chartrand.

\section{REFERENCES}

Abouchami, W., Boher, M., Michard, A., and Albarede, F., 1990, A major 2.1 Ga event of mafic magmatism in west Africa: An early stage of crustal accretion Journal of Geophysical Research, v. 95, p. 17605-17629, http://dx.doi.org/ 10.1029/JB095iB11p17605.

Allard, G.O., 1976, Doré Lake Complex and its importance to Chibougamau geology and metallogeny: Ministère des Richesses naturelles du Québec, 487 p.

Allen, R.L., Weihed, P., Blandell, D., Crawford, T., Davidson, G., Galley, A., Gibson, H., Hannington, M., Herrington, R., Herzig, P., Large, R., Lentz, D., Maslennikov, V.V., McCutcheon, S., Peter, J., and Tornos, F., 2002, Global comparisons of volcanic-associated massive sulphide districts, in Blundell, D.J., Neubauer, F., Von Quadt, E.-Z., eds., The timing and location of major ore deposits in an evolving orogen: Geological Society, London, Special Publications, v. 204, p. 13-37, http://dx.doi.org/10.1144/GSL.SP.2002.204.01.02.

Allibone, A.H., McCuaig, T.C., Harris, D., Etheridge, M., Munroe, S., Byrne, D., Amanor, J., and Gyapong, W., 2002, Structural controls on gold mineralization at the Ashanti Deposit, Obuasi, Ghana, in Goldfarb, R.J., and Nielsen, R.L., eds., Integrated methods for discovery: global exploration in the twenty-first century: Society of Economic Geologists, Special Publication, v. 9, p. 65-93.

Alvarez, W., 2010, Protracted continental collisions argue for continental plates driven by basal traction: Earth and Planetary Science Letters, v. 296, p. 434-442, http://dx.doi.org/10.1016/j.epsl.2010.05.030.

Angerer, T., Duuring, P., Lascelles, D.F., and Hagemann, S.G., 2010, BIF-related iron ore in the Yilgarn Craton, Western Australia: Geological Setting and ore forming Processes (Abstract): Fifth International Archean Symposium Abstracts, Geological Survey of Western Australia, p. 277-280.

Angerer, T., Kerrich, R., and Hagemann, S.G., 2013, Geochemistry of a komatiitic, boninitic, and tholeiitic basalt association in the Mesoarchean Koolyanobbing greenstone belt, Southern Cross Domain, Yilgarn Craton: Implications for mantle sources and geodynamic setting of banded iron formation: Precambrian Research, v. 224, p. 110-128, http://dx.doi.org/10.1016/j.precamres.2012.09.012

Anhaeusser, C.R., 1984, Structural elements of Archaean granite-greenstone terranes as exemplified by the Barberton Mountain Land, southern Africa, in Kroener, A., and Greiling, R., eds., Precambrian tectonics illustrated: E. Schweizerbart'sche Verlagsbuchhandl, (Naegele u. Obermiller), Stuttgart, Federal Republic of Germany, p. 57-78.

Anhaeusser, C.R., 2014, Archaean greenstone belts and associated granitic rocks - A review: Journal of African Earth Sciences, v. 100, p. 684-732, http://dx.doi.org/10.1016/j.jafrearsci.2014.07.019

Ansdell, K.M., Connors, K.A., Stern, R.A., and Lucas, S.B., 1999, Coeval sedimentation, magmatism, and fold-thrust belt development in the Trans-Hudson Orogen: geochronological evidence from the Wekusko Lake area, Manitoba, Canada: Canadian Journal of Earth Sciences, v. 36, p. 293-312, http://dx.doi.org/10.1139/e98-082.

Aplin, A.C., and Macquaker, J.H.S., 2011, Mudstone diversity: Origin and implications for source, seal, and reservoir properties in petroleum systems: American Association of Petroleum Geologists Bulletin, v. 95, p. 2031-2059, http://dx.doi.org/10.1306/03281110162.

Arias, Z.G., deKemp, E.A., and Donaldson, J.A., 1986, Shallow-marine Archean stromatolites in the Eyapamikama Lake area, Superior Province, Canada (Abstract): Society of Economic Paleontologists Mineralogists, Annual Midyear Meeting, Raleigh, North Carolina, Abstracts, v. 3, p. 3.

Arndt, N.T., 1991, High Ni in Archean tholeiites: Tectonophysics, v. 187, p. 411-419, http://dx.doi.org/10.1016/0040-1951(91)90479-C.

Arndt, N.T., and Nesbitt, R.W., 1982, Geochemistry of Munro Township basalts, in Arndt, N.T., and Nisbet, E.G., eds., Komatiites: George Allen and Unwin, London, UK, p. 309-329.

Arndt, N.T., Lesher, C.M., and Barnes, S.J., 2008, Komatiite: Cambridge University Press, New York, NY, 468 p., http://dx.doi.org/10.1017/CBO9780511535550.

Ashwal, L.D., Morrison, D.A., Phinney, W.C., and Wood, J., 1983, Origin of Archean anorthosites: Evidence from the Bad Vermilion Lake anorthosite complex, Ontario: Contributions to Mineralogy and Petrology, v. 82, p. 259-273, http://dx.doi.org/10.1007/BF01166620.

Attoh, K., and Ekwueme, B.N., 1997, The West African Shield: Oxford Monographs on Geology and Geophysics, v. 35, p. 517-528.

Ayer, J., and Davis, D.W., 1997, Neoarchean evolution of differing convergent margin assemblages in the Wabigoon Subprovince: geochemical and geochronogical evidence from the Lake of the Woods greenstone belt, Superior Province, Northwestern Ontario: Precambrian Research, v. 81, p. 155-178, http://dx.doi.org/10.1016/S0301-9268(96)00033-2.

Ayer, J., Berger, B., Johns, G., Trowell, N.F., Born, P., and Mueller, W.U., 1999, Late Archean Rock types and Controls on Gold Mineralization in the southern
Abitibi Greenstone Belt of Ontario (Abstract): Geological Association of Canada Joint Annual Meeting May 1999, Sudbury, ON.

Ayer, J., Amelin, Y., Corfu, F., Kamo, S., Ketchum, J., Kwok, K., and Trowell, N., 2002a, Evolution of the Abitibi greenstone belt based on U-Pb geochronology: autochthonous volcanic construction followed by plutonism, regional deformation and sedimentation: Precambrian Research, v. 115, p. 63-95, http://dx.doi.org/10.1016/S0301-9268(02)00006-2.

Ayer, J.A., Ketchum, J.W.F., and Trowell, N.F., 2002b, New geochronological and neodymium isotopic results from the Abitibi greenstone belt, with emphasis on the timing and the tectonic implications of Neoarchean sedimentation and volcanism: Ontario Geological Survey, Open File Report 6100, p. 5-1-5-16.

Ayer, J., Thurston, P.C., Bateman, R., Dubé, B., Gibson, H.L., Hamilton, M.A., Hathway, B., Hocker, S.M., Houlé, M., Hudak, G.J., Ispolatov, V., Lafrance, B., Lesher, C.M., MacDonald, P.J., Péloquin, A.S., Piercey, S.J., Reed, L.E., and Thompson, P.H., 2005, Overview of results from the Greenstone Architecture Project: Discover Abitibi Initiative, Ontario Geological Survey, Open File Report 5984, $125 \mathrm{p}$.

Ayer, J., Goutier, J., Thurston, P., Dubé, B., and Kamber, B.S., 2010, Tectonic and metallogenic evolution of the Abitibi and Wawa Subprovinces, in Ayer, J., Easton, R.M., Beakhouse, G., Stott, G., Kelly, R.I., Debicki, E., Parker, J., and Brown, T., eds., Summary of Field Work and other Activities: Ontario Geological Survey, Sudbury, p. 41-46.

Ayres, L.D., and Thurston, P.C., 1985, Archean supracrustal sequences in the Canadian Shield: An overview, in Ayres, L.D., Thurston, P.C., Card, K.D., and Weber, W., eds., Evolution of Archean Supracrustal Sequences: Geological Association of Canada, Special Paper 28, p. 343-380.

Baadsgaard, H., Nutman, A.P., Bridgwater, D., Rosing, M., McGregor, V.R., and Allaart, J.H., 1984, The zircon geochronology of the Akilia association and Isua supracrustal belt, West Greenland: Earth and Planetary Science Letters, v. 68, p. 221-228, http://dx.doi.org/10.1016/0012-821X(84)90154-7.

Bagas, L., Smithies, R.H., and Champion, D., 2003, Geochemistry of the Corunna Downs Granitoid Complex, East Pilbara Granite-Greenstone Terrane, Western Australia: Western Australia Geological Survey, Annual Review, p. 61-69.

Baldwin, G.J., 2009, The sedimentology and geochemistry of Banded Iron Formations of the Deloro Assemblage, Bartlett Dome area, Abitibi greenstone belt, Ontario, Canada: Implications for BIF deposition and greenstone belt formation: Unpublished MSc thesis, Laurentian University, Sudbury, ON, 116 p.

Barker, F., and Arth, J.G., 1976, Generation of trondhjemitic-tonalitic liquids and Archean bimodal trondhjemite-basalt suites: Geology, v. 4, p. 596-600, http://dx.doi.org/10.1130/0091-7613(1976)4<596:GOTLAA>2.0.CO;2.

Barley, M.E., 1992, A Review of Archean volcanic-hosted massive sulfide and sulfate mineralization in Western Australia: Economic Geology, v. 87, p. 855-872, http://dx.doi.org/10.2113/gsecongeo.87.3.855.

Barley, M.E., 1997, The Pilbara Craton, in de Wit, M.J., and Ashwal, L.D., eds., Greenstone Belts: Clarendon Press, Oxford, UK, p. 657-664.

Barnes, S.J., and Van Kranendonk, M.J., 2014, Archean andesites in the east Yilgarn craton, Australia: Products of plume-crust interaction?: Lithosphere, v. 6, p. 80-92, http://dx.doi.org/10.1130/L356.1.

Barrett, T.J., and MacLean, W.H., 1999, Volcanic sequences, lithogeochemistry, and hydrothermal alteration in some bimodal volcanic-associated massive sulfide systems: Reviews in Economic Geology, v. 8, p. 101-131.

Barrie, C.T., Naldrett, A.J., and Davis, D., 1990, Geochemical constraints on the genesis of the Montcalm gabbroic complex and Ni-Cu deposit, western Abitibi Subprovince, Ontario: Canadian Mineralogist, v. 28, p. 451-474.

Barrie, C.T., Ludden, J.N., and Green, T.H., 1993, Geochemistry of volcanic rocks associated with $\mathrm{Cu}-\mathrm{Zn}$ and Ni-Cu deposits in the Abitibi subprovince: Economic Geology, v. 88, p. 1341-1358, http://dx.doi.org/10.2113/gsecongeo.88.6.1341.

Beakhouse, G., 2013, Western Wabigoon Synthesis Project: Ontario Geological Survey, Open File Report 6290, Sudbury, ON, p. 5-1-5-7.

Beakhouse, G.P., Lin, S., and Kamo, S.L., 2011, Magmatic and tectonic emplacement of the Pukaskwa batholith, Superior Province, Ontario, Canada: Canadian Journal of Earth Sciences, v. 48, p. 187-204, http://dx.doi.org/10.1139/E10-048.

Bédard, J.H., 2006, A catalytic delamination-driven model for coupled genesis of Archaean crust and sub-continental lithospheric mantle: Geochimica et Cosmochimica Acta, v. 70, p. 1188-1214, http://dx.doi.org/10.1016/ j.gca.2005.11.008.

Bédard, J.H., 2013, How many arcs can dance on the head of a plume? A 'Comment' on: A critical assessment of Neoarchean 'plume only' geodynamics: Evidence from the Superior Province, by Derek Wyman, Precambrian Research, 2012 Precambrian Research, v. 229, p. 189-197, http://dx.doi.org/10.1016/j.precamres.2012.05.004

Bédard, J.H., Brouillette, P., Madore, L., and Berclaz, A., 2003, Archaean cratonization and deformation in the northern Superior Province, Canada: an evaluation of plate tectonic versus vertical tectonic models: Precambrian Research, v. 127, p. 61-87, http://dx.doi.org/10.1016/S0301-9268(03)00181-5 
Bédard, J.H., Harris, L.B., and Thurston, P.C., 2013, The hunting of the snArc: Precambrian Research, v. 229, p. 20-48, http://dx.doi.org/10.1016/j.precamres.2012.04.001

Begg, G.C., Griffin, W.L., Natapov, L.M., O’Reilly, S.Y., Grand, S.P., O’Neill, C.J. Hronsky, J.M.A., Poudjom Djomani, Y., Swain, C.J., Deen, T., and Bowden, P., 2009, The lithospheric architecture of Africa: Seismic tomography, mantle petrology, and tectonic evolution: Geosphere, v. 5, p. 23-50, http://dx.doi.org/ 10.1130/GES00179.1.

Benn, K., and Peschler, A.P., 2005, A detachment fold model for fault zones in the Late Archean Abitibi greenstone belt: Tectonophysics, v. 400, p. 85-104 http://dx.doi.org/10.1016/j.tecto.2005.02.011.

Berger, B.R., 2001, Variation in styles of gold mineralization along the PorcupineDestor deformation zone in Ontario: An Exploration Guide: Summary of Field Work and other Activities: Ontario Geological Survey, Open File report 6070, p. 9-1 to 9-13.

Bickle, M.J., Bettenay, L.F., Boulter, C.A., Groves, D.I., and Morant, P., 1980, Horizontal tectonic interaction of an Archean gneiss belt and greenstones, Pilbara block, Western Australia: Geology, v. 8, p. 525-529, http://dx.doi.org/ 10.1130/0091-7613(1980)8<525:HTIOAA > 2.0.CO;2.

Bickle, M.J., Arndt, N.T., Nisbet, E.G., Orpen, J.L., Martin, A., Keays, R.R., and Renner, R., 1993, Geochemistry of the igneous rocks of the Belingwe greenstone belt, Zimbabwe, in Bickle, M.J., and Nisbet, E.G., eds., The geology of the Belingwe greenstone belt, Zimbabwe, a study of the evolution of Archean continental crust: A.A. Balkema, Rotterdam, p. 175-214.

Bickle, M.J., Nisbet, E.G., and Martin, A., 1994, Archean greenstone belts are not oceanic crust: The Journal of Geology, v. 102, p. 121-137, http://dx.doi.org/ $10.1086 / 629658$.

Blackburn, C.E., Johns, G.W., Ayer, J.A., and Davis, D.W., 1991, Wabigoon Subprovince, in Thurston, P.C., Williams, H.R., Sutcliffe, R.H., and Stott, G.M., eds., Geology of Ontario: Ontario Geological Survey, Special Volume 4, pt. 1, p 303-381.

Bleeker, W., 1999, Structure, Stratigraphy, and Primary Setting of the Kidd Creek Volcanogenic Massive Sulfide Deposit: A Semi-quantitative Reconstruction, in Hannington, M.D., and Barrie, C.T., eds., The Giant Kidd Creek Volcanogenic Massive Sulfide Deposit, Western Abitibi Subprovince, Canada: Economic Geology Monograph 10, p. 71-123.

Bleeker, W., 2002, Archaean tectonics: a review, with illustrations from the Slave craton, in Fowler, C.M.R., Ebinger, C.J., and Hawkesworth, C.J., eds., The Early Earth: Physical, Chemical and Biological Development: Geological Society, London, Special Publications, v. 199, p. 151-181, http://dx.doi.org/10.1144/ gsl.sp.2002.199.01.09.

Bleeker, W., 2003, The late Archean record: A puzzle in ca. 35 pieces: Lithos, v. 71 , p. 99-134, http://dx.doi.org/10.1016/j.lithos.2003.07.003.

Bleeker, W., 2012, Lode gold deposits in Deformed and metamorphosed terranes: The role of Extension in the Formation of Timiskaming Basins and Large Gold Deposits, Abitibi Greenstone Belt-A Discussion, in Parker, J., ed., Summary of Field Work and Other Activities 2012: Ontario Geological Survey, Open File Report 6280, p. 47-41 to 47-12

Bleeker, W., and Hall, B., 2007, The Slave Craton: Geological and metallogenic evolution, in Goodfellow, W.D., ed., Mineral Deposits of Canada: A synthesis of major Deposit-types, District Metallogeny, the Evolution of Geological Provinces, and Exploration Methods: Geological Association of Canada, Mineral Deposits Division, Special Publication 5, p. 849-879.

Bleeker, W., and Van Breemen, O., 2011, New geochronological, stratigraphic, and structural observations on the Kidd-Munro assemblage and the terrane architecture of the south- central Abitibi greenstone belt, Superior craton, Canada: Results from the Targeted Geoscience Initiative III Kidd-Munro Project: Ontario Geological Survey, Open File Report 6258, 142 p.

Blenkinsop, T., Fedo, C.M., Bickle, M.J., Eriksson, K.A., Martin, A., Nisbet, E.G. and Wilson, J.F., 1993, Ensialic origin for the Ngezi Group, Belingwe greenstone belt, Zimbabwe: Geology, v. 21, p. 1135-1138, http://dx.doi.org/ 10.1130/0091-7613(1993)021<1135:EOFTNG>2.3.CO;2.

Blenkinsop, T., Martin, A., Jelsma, H.A., and Vinyu, M.L., 1997, The Zimbabwe craton, in de Wit, M.J., and Ashwal, L.D., eds., Greenstone Belts: Clarendon Press, Oxford, UK, p. 567-580.

Blewett, R.S., 2002, Archaean tectonic processes: A case for horizontal shortening in the North Pilbara Granite-Greenstone Terrane, Western Australia: Precambrian Research, v. 113, p. 87-120, http://dx.doi.org/10.1016/S0301 9268(01)00204-2.

Blewett, R.S., Champion, D.C., Whitaker, A.J., Bell, B., Nicoll, M., Goleby, B.R., Cassidy, K.F., and Groenewald, P.B., 2002, Three dimensional (3D) model of the Leonora-Laverton transect area: implications for Eastern Goldfields tectonics and mineralisation, in Cassidy, K.F., ed., Geology, geochronology and geophysics of the north eastern Yilgarn Craton, with an emphasis on the Leonora-Laverton transect area: Geoscience Australia, p. 83-100.

Bloem, E.J.M., Dalstra, H.J., Ridley, J.R., and Groves, D.I., 1997, Granitoid diapirism during protracted tectonism in an Archaean granitoid-greenstone belt, Yilgarn Block, Western Australia: Precambrian Research, v. 85, p. 147-171, http://dx.doi.org/10.1016/S0301-9268(97)00034-X.

Boily, M., and Dion, C., 2002, Geochemistry of boninite-type volcanic rocks in the Frotet-Evans greenstone belt, Opatica subprovince, Quebec: implications for the evolution of Archaean greenstone belts: Precambrian Research, v. 115, p. 349-371, http://dx.doi.org/10.1016/S0301-9268(02)00016-5.

Bolhar, R., Van Kranendonk, M.J., and Kamber, B.S., 2005, A trace element study of siderite-jasper banded iron formation in the 3.45 Ga Warrawoona Group, Pilbara Craton-Formation from hydrothermal fluids and shallow seawater: Precambrian Research, v. 137, p. 93-114, http://dx.doi.org/10.1016/j.precamres.2005.02.001

Bouma, A.H., 2000, Fine-grained, mud-rich turbidite systems: model and comparison with coarse-grained, sand-rich systems: American Association of Petroleum Geologists Memoir 72, SEPM Special Publication 68, p. 9-20.

Bradley, D.C., 2011, Secular trends in the geologic record and the supercontinent cycle: Earth-Science Reviews, v. 108, p. 16-33, http://dx.doi.org/10.1016/ j.earscirev.2011.05.003

Breaks, F.W., 1991, English River Subprovince: Ontario Geological Survey Special Volume 4, p. 239-277.

Breaks, F.W., and Moore, J.M., Jr., 1992, The Ghost Lake Batholith, Superior Province of Northwestern Ontario: a fertile peraluminous S-Type granite rare element pegmatite system: Canadian Mineralogist, v. 30, p. 835-875.

Breaks, F.W., Osmani, I.A., and deKemp, E.A., 2001, Geology of the North Caribou Lake area, north-western Ontario: Ontario Geological Survey, Open File Report 6023, $70 \mathrm{p}$.

Brooks, C., Ludden, J., Pigeon, Y., and Hubregtse, J.J.M.W., 1982, Volcanism of shoshonite to high- $\mathrm{K}$ andesite affinity in an Archean arc environment, Oxford Lake, Manitoba: Canadian Journal of Earth Sciences, v. 19, p. 55-67, http://dx.doi.org/10.1139/e82-005

Brown, G.H., 1995, Precambrian Geology, Oliver and Ware Townships: Ontario Geological Survey, Geological Report 294, 48 p.

Brown, M., 2006, Duality of thermal regimes is the distinctive characteristic of plate tectonics since the Neoarchean: Geology, v. 34, p. 961-964, http://dx.doi.org/ 10.1130/G22853A.1.

Brown, M., 2007, Metamorphic conditions in orogenic belts: A record of secular change: International Geology Review, v. 49, p. 193-234, http://dx.doi.org/ 10.2747/0020-6814.49.3.193.

Brown, S.J.A., Barley, M.E., Krapež, B., and Cas, R.A.F., 2002, The Late Archaean Melita Complex, Eastern Goldfields, Western Australia: shallow submarine bimodal volcanism in a rifted arc environment: Journal of Volcanology and Geothermal Research, v. 115, p. 303-327, http://dx.doi.org/10.1016/S03770273(01)00314-6.

Buick, R., Thornett, J.R., McNaughton, N.J., Smith, J.B., Barley, M.E., and Savage, M., 1995, Record of emergent continental crust $\sim 3.5$ billion years ago in the Pilbara craton of Australia: Nature, v. 375, p. 574-577, http://dx.doi.org/ $10.1038 / 375574 \mathrm{a} 0$.

Buse, S., Lewis, D., Davis, D.W., and Hamilton, M.A., 2010, U-Pb geochronological results from the Lumby Lake greenstone belt, Wabigoon Subprovince, Northwestern Ontario: Summary of Field work and other Activities, 2010: Ontario Geological Survey, Open File Report 6260, p. 12-1 to12-9.

Calvert, A.J., and Ludden, J.N., 1999, Archean continental assembly in the southeastern Superior Province of Canada: Tectonics, v. 18, p. 412-429, http://dx.doi.org/10.1029/1999TC900006.

Calvert, A.J., Sawyer, E.W., Davis, W.J., and Ludden, J.N., 1995, Archaean subduction inferred from seismic images of a mantle suture in the Superior Province: Nature, v. 375, p. 670-674, http://dx.doi.org/10.1038/375670a0.

Calvert, A.J., Cruden, A.R., and Hynes, A., 2004, Seismic evidence for preservation of the Archean Uchi granite-greenstone belt by crustal-scale extension: Tectonophysic, v. 388, p. 135-143, http://dx.doi.org/10.1016/ j.tecto.2004.07.043.

Campbell, I.H., Franklin, J.M., Gorton, M.P., Hart, T.R., and Scott, S.D., 1981, The role of subvolcanic sills in the generation of massive sulfide deposits: Economic Geology, v. 76, p. 2248-2253, http://dx.doi.org/10.2113/gsecongeo.76.8.2248.

Campbell, I.H., Coad, P., Franklin, J.M., Gorton, M.P., Scott, S.D., Sowa, J., and Thurston, P.C., 1982, Rare earth elements in volcanic rocks associated with $\mathrm{Cu}-\mathrm{Zn}$ massive sulphide mineralization: a preliminary report: Canadian Journal of Earth Sciences, v. 19, p. 619-623, http://dx.doi.org/10.1139/e82-049.

Campbell, I.H., Griffiths, R.W., and Hill, R.I., 1989, Melting in an Archaean mantle plume: heads it's basalts, tails it's komatiites: Nature, v. 339, p. 697-699, http://dx.doi.org/10.1038/339697a0.

Capdevila, R., Goodwin, A.M., Ujike, O., and Gorton, M.P., 1982, Trace-element geochemistry of Archean volcanic rocks and crustal growth in southwestern Abitibi Belt, Canada: Geology, v. 10, p. 418-422, http://dx.doi.org/10.1130/ 0091-7613(1982)10<418:TGOAVR>2.0.CO;2. 
Card, K.D., 1990, A review of the Superior Province of the Canadian Shield, a product of Archean accretion: Precambrian Research, v. 48, p. 99-156, http:/ /dx.doi.org/10.1016/0301-9268(90)90059-Y.

Carignan, J., Gariépy, C., Machado, N., and Rive, M., 1993, Pb isotopic geochemistry of granitoids and gneisses from the late Archean Pontiac and Abitibi Subprovinces of Canada: Chemical Geology, v. 106, p. 299-315, http:/ /dx.doi.org/ 10.1016/0009-2541(93)90033-F.

Carmichael, I.S.E., 1964, The petrology of Thingmuli, a Tertiary volcano in eastern Iceland: Journal of Petrology, v. 5, p. 435-460, http://dx.doi.org/10.1093/ petrology/5.3.435

Carson, H.J.E., Lesher, C.M., Houlé, M.G., Weston, R.J., and Shinkle, D.A., 2013, Stratigraphy, Geochemistry and Petrogenesis of the Black Thor Intrusive Complex and Associated Chromium and Ni-Cu-PGE Mineralization, McFaulds Lake Greenstone belt, Ontario: Summary of Field work and other Activities: Ontario Geological Survey, Open File Report 6290, p. 52-51 to 52-15.

Carter, M.W., 1993, The geochemical characteristics of Neoarchean alkalic magmatism in the central Superior Province: Ontario Geological Survey, Miscellaneous Paper 162, p. 13-19.

Champion, D.C., and Smithies, R.H., 2007, Geochemistry of Paleoarchean granites of the East Pilbara Terrane, Pilbara Craton, Western Australia: implications for early Archean crustal growth: Developments in Precambrian Geology, v. 15, p 369-409.

Chardon, D., Choukroune, P., and Jayananda, M., 1996, Strain patterns, décollement and incipient sagducted greenstone terrains in the Archaean Dharwar Craton (South India): Journal of Structural Geology, v. 18, p. 991-1004 http://dx.doi.org/10.1016/0191-8141(96)00031-4.

Choukroune, P., Ludden, J.N., Chardon, D., Calvert, A.J., and Bouhallier, H., 1997, Archaean crustal growth and tectonic processes: a comparison of the Superior Province, Canada and the Dharwar Craton, India, in Gurg, J.-P., and Ford, M., Orogeny Through Time: Geological Society, London, Special Publications, v. 121, p. 63-98, http://dx.doi.org/10.1144/GSL.SP.1997.121.01.04

Claoué-Long, J.C., Compston, W., and Cowden, A., 1988, The age of the Kambalda greenstones resolved by ion-microprobe: implications for Archaean dating methods: Earth and Planetary Science Letters, v. 89, p. 239-259, http://dx.doi.org/10.1016/0012-821X(88)90175-6.

Condie, K.C., 1981, Archean Greenstone Belts: Elsevier, Amsterdam, 433 p.

Condie, K.C., 1986, Origin and early growth rate of continents: Precambrian Research, v. 32, p. 261-278, http://dx.doi.org/10.1016/0301-9268(86)90032$\mathrm{X}$.

Condie, K.C., 1993, Chemical composition and evolution of the upper continental crust: Contrasting results from surface samples and shales: Chemical Geology, v. 104, p. 1-37, http://dx.doi.org/10.1016/0009-2541(93)90140-E

Condie, K.C., and Benn, K., 2006, Archean geodynamics: Similar to or different from modern geodynamics?, in Benn, K., Mareschal, J.-C., and Condie, K.C., eds., Archean Geodynamics and Environments: American Geophysical Union Monograph Series, v. 164, p. 47-59, http://dx.doi.org/10.1029/164gm05.

Condie, K.C., Kröner, A., and Stern, R.J., 2006, Penrose conference report: When did plate tectonics begin?: GSA Today, v. 16, p. 40-41.

Cooke, D.L., 1966, The Timiskaming Volcanics and Associated Sediments of the Kirkland lake Area: Unpublished PhD thesis, University of Toronto, Toronto, ON, 147 p.

Corcoran, P.L., and Mueller, W.U., 2007, Time-transgressive Archean unconformities underlying molasse basin-fill successions of dissected oceanic arcs, Superior Province, Canada: The Journal of Geology, v. 115, p. 655-674, http://dx.doi.org/10.1086/521609.

Corfu, F., and Noble, S.R., 1992, Genesis of the southern Abitibi greenstone belt, Superior Province, Canada: Evidence from zircon Hf isotope analyses using a single filament technique: Geochimica et Cosmochimica Acta, v. 56, p. 2081-2097, http://dx.doi.org/10.1016/0016-7037(92)90331-C.

Corfu, F., and Stone, D., 1998, Age structure and orogenic significance of the Berens River composite batholiths, western Superior Province: Canadian Journal of Earth Sciences, v. 35, p. 1089-1109, http://dx.doi.org/10.1139/e98-056.

Cousens, B.L., 2000, Geochemistry of the Archean Kam Group, Yellowknife greenstone belt, Slave Province, Canada: The Journal of Geology, v. 108, p. 181-197, http://dx.doi.org/10.1086/314397.

Crawford, A.J., Falloon, T.J., and Green, D.H., 1989, Classification, petrogenesis and tectonic setting of boninites, in Crawford, A.J., ed., Boninites: Unwin Hyman, London, UK, p. 1-49.

D’Orazio, M., Agostini, S., Mazzarini, F., Innocenti, F., Manetti, P., Haller, M.J., and Lahsen, A., 2000, The Pali Aike Volcanic Field, Patagonia: Slab-window magmatism near the tip of South America: Tectonophysics, v. 321, p. 407-427, http://dx.doi.org/10.1016/S0040-1951(00)00082-2.

Daigneault, R., and Allard, G.O., 1990, Le Complexe du Lac Doré et son environnement géologique: Ministère de l'Eneregie et des Ressources du Québec, DPV 368, $275 \mathrm{p}$.

Dann, J.C., 2001, Vesicular komatiites, 3.5-Ga Komati Formation, Barberton Green- stone Belt, South Africa: Inflation of submarine lavas and origin of spinifex zones: Bulletin of Volcanology, v. 63, p. 462-481, http://dx.doi.org/10.1007/ s004450100164.

Davis, D.W., 1990, The Seine-Coutchiching problem reconsidered: U-Pb geochronological data concerning the source and timing of Archean sedimentation in the western Superior Province (Abstract): Institute on Lake Superior Geology, Abstracts, v. 36, p. 19-21.

Davis, D.W., 1993, Report on U-Pb geochronology in the Atikokan area, Wabigoon subprovince: Royal Ontario Museum Report, Toronto, ON, p. 9.

Davis, D.W., and Edwards, G.R., 1986, Crustal evolution of Archean rocks in the Kakagi Lake area, Wabigoon Subprovince, Ontario, as interpreted from highprecision U-Pb geochronology: Canadian Journal of Earth Sciences, v. 23, p. 182-192, http://dx.doi.org/10.1139/e86-021.

Davis, D.W., Pezzutto, F., and Ojakangas, R.W., 1990, The age and provenance of metasedimentary rocks in the Quetico Subprovince, Ontario, from single zircon analyses: implications for Archean sedimentation and tectonics in the Superior Province: Earth and Planetary Science Letters, v. 99, p. 195-205, http://dx.doi.org/10.1016/0012-821X(90)90110-J

Davis, W.J., Lacroix, S., Gariépy, C., and Machado, N., 2000, Geochronology and radiogenic isotope geochemistry of plutonic rocks from the central Abitibi subprovince: significance to the internal subdivision and plutono-tectonic evolution of the Abitibi belt: Canadian Journal of Earth Sciences, v. 37, p. 117-133, http://dx.doi.org/10.1139/e99-093

de Rosen-Spence, A.F., 1976, Stratigraphy, development and petrogenesis of the central Noranda volcanic pile, Noranda, Quebec: Unpublished PhD thesis, University of Toronto, Toronto, ON, $439 \mathrm{p}$

de Rosen-Spence, A.F., Provost, G., Dimroth, E., Gochnauer, K., and Owen, V., 1980, Archean subaqueous felsic flows, Rouyn-Noranda, Quebec, Canada, and their Quaternary equivalents: Precambrian Research, v. 12, p. 43-77, http://dx.doi.org/10.1016/0301-9268(80)90023-6.

de Wit, M.J., Hart, R.A., and Hart, R.J., 1987, The Jamestown Ophiolite Complex, Barberton mountain belt: a section through $3.5 \mathrm{Ga}$ oceanic crust: Journal of African Earth Sciences, v. 6, p. 681-730, http://dx.doi.org/10.1016/08995362(87)90007-8.

Defant, M.J., and Drummond, M.S., 1990, Derivation of some modern arc magmas by melting of young subducted lithosphere: Nature, v. 347, p. 662-665, http://dx.doi.org/10.1038/347662a0.

Defant, M.J., and Drummond, M.S., 1993, Mount St. Helens: Potential example of the partial melting of the subducted lithosphere in a volcanic arc: Geology, v. 21, p. 547-550, http://dx.doi.org/10.1130/0091-7613(1993)021<0547:MSH$\mathrm{PEO}>2.3 . \mathrm{CO} ; 2$.

Defant, M.J., Jackson, T.E., Drummond, M.S., De Boher, J.Z., Bellon, H., Feigenson, M.D., Maury, R.C., and Stewart, R.H., 1992, The geochemistry of young volcanism throughout western Panama and southeastern Costa Rica: an overview: Journal of the Geological Society, v. 149, p. 569-579, http://dx.doi.org/ 10.1144/gsjgs.149.4.0569.

Depaolo, D.J., 1981, Trace element and isotopic effects of combined wallrock assimilation and fractional crystallization: Earth and Planetary Science Letters, v. 53, p. 189-202, http://dx.doi.org/10.1016/0012-821X(81)90153-9.

Devaney, J.R., and Williams, H.R., 1989, Evolution of an Archean subprovince boundary: a sedimentological and structural study of part of the WabigoonQuetico boundary in northern Ontario: Canadian Journal of Earth Sciences, v. 26, p. 1013-1026, http://dx.doi.org/10.1139/e89-082.

Dhuime, B., Hawkesworth, C.J., Cawood, P.A., and Storey, C.D., 2012, A change in the Geodynamics of Continental Growth 3 Billion Years ago: Science, v. 335 , p. 1334-1336, http://dx.doi.org/10.1126/science.1216066

Dilek, Y., and Polat, A., 2008, Suprasubduction zone ophiolites and Archean tectonics: Geology, v. 36, p. 431-432, http://dx.doi.org/10.1130/Focus052008.1.

Dimroth, E., and Lichtblau, A.P., 1979, Metamorphic evolution of Archean hyaloclastites, Noranda area, Quebec, Canada. Part I: Comparison of Archean and Cenozoic sea-floor metamorphism: Canadian Journal of Earth Sciences, v. 16, p. 1315-1340, http://dx.doi.org/10.1139/e79-120

Dimroth, E., and Rocheleau, M., 1979, Volcanology and sedimentology of the Rouyn-Noranda area, Quebec: Geological Association of Canada Field Trip A1 Guide Book, Université Laval, Quebec, 193 p.

Dimroth, E., Côté, R., Provost, G., Rocheleau, M., Tassé, N., and Trudel, P., 1974 Third progress report on the stratigraphy, volcanology, sedimentology and structure of the Rouyn-Noranda area, counties of Rouyn-Noranda, Abitibiwest and Temiskamingue: Ministère des Richesses naturelles (Québec), 64 p.

Dimroth, E., Imreh, L., Rocheleau, M., and Goulet, N., 1982, Evolution of the south-central part of the Archean Abitibi Belt, Quebec. Part 1: Stratigraphy and paleogeographic model: Canadian Journal of Earth Sciences, v. 19, p. 1729-1758, http://dx.doi.org/10.1139/e82-154

Dimroth, E., Imreh, L., Goulet, N., and Rocheleau, M., 1983, Evolution of the south-central segment of the Archean Abitibi Belt, Quebec. Part III: Plutonic and metamorphic evolution and geotectonic model: Canadian Journal of Earth 
Sciences, v. 20, p. 1374-1388, http://dx.doi.org/10.1139/e83-125.

Dimroth, E., Imreh, L., Cousineau, P., Leduc, M., and Sanschagrin, Y., 1985, Paleogeographic analysis of mafic submarine flows and its use in the exploration for Massive Sulphide Deposits, in Ayres, L.D., Thurston, P.C., Card, K.D., and Weber, W., eds., Evolution of Archean Supracrustal Sequences: Geological Association of Canada, Special Paper 28, p. 203-222.

Donaldson, J.A., and de Kemp, E.A., 1998, Archaean quartz arenites in the Canadian Shield: examples from the Superior and Churchill Provinces: Sedimentary Geology, v. 120, p. 153-176, http://dx.doi.org/10.1016/S0037-0738(98)000311.

Dostal, J., and Mueller, W., 1992, Archean shoshonites from the Abitibi greenstone belt, Chibougamau (Québec, Canada): geochemistry and tectonic setting: Journal of Volcanology and Geothermal Research, v. 53, p. 145-165, http:/ /dx.doi.org/10.1016/0377-0273(92)90079-S

Dostal, J., and Mueller, W.U., 1997, Komatiite flooding of a rifted Archean rhyolitic arc complex: geochemical signature and tectonic significance of the StoughtonRoquemaure Group, Abitibi Greenstone Belt, Canada: The Journal of Geology, v. 105, p. 545-563, http://dx.doi.org/10.1086/515956.

Dostal, J., and Mueller, W.U., 2013, Deciphering an Archean mantle plume: Abitibi greenstone belt, Canada: Gondwana Research, v. 23, p. 493-505, http://dx.doi.org/10.1016/j.gr.2012.02.005.

Dostal, J., Mueller, W.U., and Murphy, J.B., 2004, Archean molasse basin evolution and magmatism, Wabigoon Subprovince, Canada: The Journal of Geology, v 112, p. 435-454, http://dx.doi.org/10.1086/421073.

Drummond, B.J., 1988, A review of crust/upper mantle structure in the Precambrian areas of Australia and implications for Precambrian crustal evolution: Precambrian Research, v. 40-41, p. 101-116, http://dx.doi.org/10.1016/0301 9268(88)90063-0.

Drummond, M.S., and Defant, M.J., 1990, A model for trondhjemite-tonalite-dacite genesis and crustal growth via slab melting: Archean to modern comparisons: Journal of Geophysical Research, v. 95, p. 21503-21521, http://dx.doi.org/ 10.1029/JB095iB13p21503.

Drury, S.A., 1977, Structures induced by granite diapirs in the Archaean greenstone belt at Yellowknife, Canada: Implications for Archaean geotectonics: The Journal of Geology, v. 85, p. 345-358, http://dx.doi.org/10.1086/628304.

Dubé, B., Williamson, K., McNicoll, V., Malo, M., Skulski, T., Twomey, T., and Sanborn-Barrie, M., 2004, Timing of gold mineralization at Red Lake, Northwestern Ontario, Canada: New constraints from U-Pb geochronology at the Goldcorp high-grade zone, Red lake Mine, and the Madsen Mine: Economic Geology, v. 99, p. 1611-1641, http://dx.doi.org/10.2113/99.8.1611.

Easton, R.M., 2000, Metamorphism of the Canadian Shield, Ontario, Canada. I. The Superior Province: The Canadian Mineralogist, v. 38, p. 287-317, http://dx.doi.org/10.2113/gscanmin.38.2.287.

Eglington, B.M., and Armstrong, R.A., 2004, The Kaapvaal Craton and adjacent orogens, southern Africa: a geochronological database and overview of the geological development of the craton: South African Journal of Geology, v. 107, p. 13-32, http://dx.doi.org/10.2113/107.1-2.13.

Eriksson, K.A., and Soegaard, K., 1985, The petrography and geochemistry of Archaean and Early Proterozoic sediments: implications for crustal compositions and surface processes (South Africa, Australia, USA): Bulletin - Geological Survey of Finland, v. 331, p. 7-32.

Ernst, W.G., and Liou, J.G., 1999, Overview of UHP metamorphism and tectonics in well-studied collisional orogens: International Geology Review, v. 41, p. 477-493, http://dx.doi.org/10.1080/00206819909465153

Ewart, A., 1982, The mineralogy and petrology of Tertiary-Recent orogenic vol canic rocks: with special reference to the andesitic-basaltic compositional range, in Thorpe, R.S., ed., Andesites: orogenic andesites and related rocks: John Wiley and Sons, Chichester, UK, p. 25-95.

Farquhar, J., and Wing, B.A., 2003, Multiple sulfur isotopes and the evolution of the atmosphere: Earth and Planetary Science Letters, v. 213, p. 1-13, http://dx.doi.org/10.1016/S0012-821X(03)00296-6.

Feng, R., and Kerrich, R., 1992, Geodynamic evolution of the southern Abitibi and Pontiac terranes: evidence from geochemistry of granitoid magma series (2700-2630 Ma): Canadian Journal of Earth Sciences, v. 29, p. 2266-2286, http://dx.doi.org/10.1139/e92-178.

Ferguson, I.J., Craven, J.A., Kurtz, R.D., Boerner, D.E., Bailey, R.C., Wu, X., Orellana, M.R., Spratt, J., Wennberg, G., and Norton, M., 2005, Geoelectric response of Archean lithosphere in the western Superior Province, central Canada: Physics of the Earth and Planetary Interiors, v. 150, p. 123-143, http://dx.doi.org/10.1016/j.pepi.2004.08.025.

Flint, D.J., 2010, REE, lithium, potash, and phosphate mineralization in Western Australia: Record - Geological Survey of Western Australia, p. 33-34.

Fralick, P., and Pufahl, P.K., 2006, Iron formation in Neoarchean deltaic successions and the microbially mediated deposition of transgressive systems tracts: Journal of Sedimentary Research v. 76, p. 1057-1066, http://dx.doi.org/10.2110/ jsr.2006.095
Fralick, P., Hollings, P., and King, D., 2008, Stratigraphy, geochemistry, and depositional environments of Mesoarchean sedimentary units in western Superior Province: Implications for generation of early crust, in Condie, K.C., and Pease, V., eds., When Did Plate Tectonics Begin on Planet Earth?: Geological Society of America, Special Papers, v. 440, p. 77-96, http://dx.doi.org/10.1130/ 2008.2440(04)

Francis, D., Ludden, J., Johnstone, R., and Davis, W., 1999, Picrite evidence for more Fe in Archean mantle reservoirs: Earth and Planetary Science Letters, v. 167, p 197-213, http://dx.doi.org/10.1016/S0012-821X(99)00032-1.

Franklin, J.M., Gibson, H.L., Jonasson, I.R., and Galley, A.G., 2005, Volcanogenic Massive sulfide Deposits: Economic Geology 100th Anniversary Volume, p. 523-560.

Fumerton, S.L., Stauffer, M.R., and Lewry, J.F., 1984, The Wathaman batholith: largest known Precambrian pluton: Canadian Journal of Earth Sciences, v. 21, p. 1082-1097, http://dx.doi.org/10.1139/e84-113.

Furnes, H., de Wit, M., and Robins, B., 2013, A review of new interpretations of the tectonostratigraphy, geochemistry and evolution of the Onverwacht Suite, Barberton Greenstone Belt, South Africa: Gondwana Research, v. 23, p. 403-428, http://dx.doi.org/10.1016/j.gr.2012.05.007.

Fyon, J.A., Breaks, F.W., Heather, K.B., Jackson, S.L., Muir, T.L., Stott, G., and Thurston, P.C., 1992, Metallogeny of Metallic Mineral Deposits in the Superior Province of Ontario, in Thurston, P.C., Williams, H.R., Sutcliffe, H.R., and Stott, G.M., eds., Geology of Ontario: Ontario Geological Survey, Special Volume 4, p. 1091-1174.

Gaál, G., and Gorbatschev, R., 1987, An outline of the Precambrian evolution of the Baltic Shield: Precambrian Research, v. 35, p. 15-52, http://dx.doi.org/ 10.1016/0301-9268(87)90044-1.

Gaillard, N., Williams-Jones, A.E., Salvi, S., Beziat, D., Perrouty, S., Van Hinsberg, V., Linnen, R., Olivo, G.r., Piercey, S.J., and Wares, R.P., 2014, Canadian Malartic gold deposit footprint: Preliminary investigation of geological, geochemical and mineralogical features (Abstract): GAC-MAC Annual Meeting, Fredericton, NB, Abstracts, v. 37, p. 97

Galley, A.G., Hannington, M.D., and Jonasson, I.R., 2007a, Volcanogenic Massive Sulphide Deposits, in Goodfellow, W., ed., Mineral Deposits of Canada: A Synthesis of Major Deposit-types, District Metallogeny, the Evolution of Geological Provinces, and Exploration Methods: Geological Associaton of Canada, Mineral Deposits Division, Special Publication 5, p. 141-162.

Galley, A.G., Syme, R., and Bailes, A., 2007b, Metallogeny of thePpaleoproterozoic Flin Flon belt, Manitoba and Saskatchewan, in Goodfellow, W., ed., Mineral Deposits of Canada: A Synthesis of Major Deposit-types, District Metallogeny, the Evolution of Geological Provinces, and Exploration Methods: Geological Associaton of Canada, Mineral Deposits Division, Special Publication 5, p. 509-531.

Gee, R.D., Baxter, J.L., Wilde, S.A., and Williams, I.R., 1981, Crustal development in the Archaean Yilgarn block, western Australia: Geological Society of Australia Special Publication, v. 7, p. 43-56.

Gélinas, L., Brooks, C., and Trzcienski, W.E., Jr., 1976, Archean variolites - quenched immiscible liquids: Canadian Journal of Earth Sciences, v. 13, p. 210-230, http://dx.doi.org/10.1139/e76-024.

Gélinas, L., Brooks, C., Perrault, G., Carignan, J., Trudel, P., and Grasso, F., 1977, Chemostratigraphic divisions within the Abitibi volcanic belt, Rouyn-Noranda, Québec, in Baragar, W.R.A., Coleman, L.C., and Hall, J.M., eds., Volcanic Regimes in Canada: Geological Association of Canada, Special Paper 16, p. $265-295$.

Gibson, H.L., and Watkinson, D.H., 1990, Volcanogenic massive sulphide deposits of the Noranda Cauldron and shield Volcano, Quebec, in Rive, M., Verpaelst P., Gagnon, Y., Lulin, J.-M., Riverin, G., and Simard, A., eds., The Northwestern Quebec Polymetallic Belt: A summary of 60 years of mining exploration: Canadian Institute of Mining and Metallurgy, p. 119-132.

Gibson, H.L., Pehrsson, S., Thurston, P., and Lafrance, B., 2011, Volcanogenic Massive sulphide Deposits of the Paleoproterozoic Trans-Hudson Orogen and the Archean Abitibi subprovince: Characteristics and Metallogeny (Abstract): GAC-MAC Annual Meeting, Ottawa, ON, Abstracts v. 34, p. 75.

Gill, J.B., 1981, Orogenic Andesites and Plate Tectonics: Minerals and Rocks, v. 16, Springer-Verlag Berlin Heidelberg, 392 p., http://dx.doi.org/10.1007/978-3 642-68012-0.

Gleason, J.D., Moore, T.C., Jr., Johnson, T.M., Rea, D.K., Owen, R.M., Blum, J.D., Pares, J., and Hovan, S.A., 2004, Age calibration of piston core EW9709-07 (equatorial central Pacific) using fish teeth $\mathrm{Sr}$ isotope stratigraphy: Palaeogeography, Palaeoclimatology, Palaeoecology, v. 212, p. 355-366, http://dx.doi.org/ 10.1016/S0031-0182(04)00366-9.

Goldfarb, R.J., Baker, T., Dubé, B., Groves, D.I., Hart, C.J.R., and Gosselin, P., 2005, Distribution, character, and genesis of gold geposits in metamorphic terranes, in Hedenquist, J.W., Thompson, J.F.H., Goldfarb, R.J., and Richards, J.P., eds., Economic Geology 100 ${ }^{\text {th }}$ Anniversary Volume, Society of Economic Geologists, p. $407-450$. 
Goldstein, S.B., and Francis, D., 2008, The petrogenesis and mantle source of Archaean ferropicrites from the Western Superior Province, Ontario, Canada: Journal of Petrology, v. 49, p. 1729-1753, http://dx.doi.org/10.1093/petrology/egn044.

Goleby, B.R., Blewett, R.S., Korsch, R.J., Champion, D.C., Cassidy, K.F., Jones, L.E.A., Groenewald, P.B., and Henson, P., 2004, Deep seismic reflection profiling in the Archaean northeastern Yilgarn Craton, Western Australia: implications for crustal architecture and mineral potential: Tectonophysics, v. 388, p. 119-133, http://dx.doi.org/10.1016/j.tecto.2004.04.032.

Goleby, B.R., Blewett, R.S., Fomin, T., Fishwick, S., Reading, A.M., Henson, P.A., Kennett, B.L.N., Champion, D.C., Jones, L., Drummond, B.J., and Nicoll, M., 2006, An integrated multi-scale 3D seismic model of the Archaean Yilgarn Craton, Australia: Tectonophysics, v. 420, p. 75-90, http://dx.doi.org/10.1016/ j.tecto.2006.01.028.

Goscombe, B., Blewett, R., Foster, D., and Wade, B., 2012, Thermobarometric evolution of subdomains within the western Yilgarn Craton: Record - Geological Survey of Western Australia, p. 6-9.

Goutier, J., 2006, Géologie de la région du lac au Goéland (32F/15): Ministère des Ressources Naturelles et de la Faune, Québec, Rapport Géologique RG 2005 05 , p. 44.

Goutier, J., Dion, C., Ouellet, M.-C., David, J., and Parent, M., 2000, Géologie de la région des lacs Guillaumat et Sakami (33F/002 et 33F/07): Géologie Québec, Rapport Géologique, 99-05, p. 40.

Grav, R., and Pysklywec, R.N., 2010, Geodynamic models of Archean continental collision and the formation of mantle lithosphere keels: Geophysical Research Letters, v. 37, L19301, http://dx.doi.org/10.1029/2010gl043965.

Green, J.C., and Schulz, K.J., 1977, Iron-rich basaltic komatiites in the early Precambrian Vermilion District, Minnesota: Canadian Journal of Earth Sciences, v. 14, p. 2181-2192, http://dx.doi.org/10.1139/e77-188.

Griffin, W.L., O’Reilly, S.Y., Abe, N., Aulbach, S., Davies, R.M., Pearson, N.J., Doyle, B.J., and Kivi, K., 2003, The origin and evolution of the Archean lithospheric mantle: Precambrian Research, v. 127, p. 19-41, http://dx.doi.org/10.1016/ S0301-9268(03)00180-3.

Gromet, L.P., and Silver, L.T., 1987, REE variations across the Peninsular Ranges batholith: Implications for batholithic petrogenesis and crustal growth in magmatic arcs: Journal of Petrology, v. 28, p. 75-125, http://dx.doi.org/10.1093/ petrology/28.1.75

Grove, T.L., and Parman, S.W., 2004, Thermal evolution of the Earth as recorded by komatiites: Earth and Planetary Science Letters, v. 219, p. 173-187, http:/ /dx.doi.org/10.1016/S0012-821X(04)00002-0.

Gunning, H.C., and Ambrose, J.W., 1939, The Timiskaming-Keewatin problem in the Rouyn-Harricanaw Region, Northwestern Quebec: Transactions of the Royal Society of Canada, Series 3, v. 33, p. 19-49.

Gupta, V.K., 1991, Shaded image of total magnetic field of Ontario: Maps 2585-88: Ontario Geological Survey, scale 1:1,000,000.

Gupta, V.K., Thurston, P.C., and Dusanowskyj, T.H., 1982, Constraints upon models of greenstone belt evolution by gravity modelling, Birch-Uchi greenstone belt, northern Ontario: Precambrian Research, v. 16, p. 233-255, http://dx.doi.org/10.1016/0301-9268(82)90062-6.

Hale, C.J., and Lloyd, P., 1989, Grant 342: Paleomagnetic analysis of regional and contact strains: Ontario Geological Survey, Miscellaneous Paper 143, p. 199-209.

Hallberg, J.A., 1986, Archaean basin development and crustal extension in the northeastern Yilgarn Block, Western Australia: Precambrian Research, v. 31, p. 133-156, http://dx.doi.org/10.1016/0301-9268(86)90071-9.

Hamilton, W.B., 1998, Archean magmatism and deformation were not products of plate tectonics: Precambrian Research, v. 91, p. 143-179, http://dx.doi.org/ 10.1016/S0301-9268(98)00042-4.

Hamilton, W.B., 2007, Driving mechanism and 3-D circulation of plate tectonics, in Sears, J.W., Harms, T.A., and Evenchick, C.A., eds., Whence the Mountains? Inquiries into the Evolution of Orogenic Systems: A Volume in Honor of Raymond A. Price: Geological Society of America, Special Papers, v. 433, p. 1-25, http://dx.doi.org/10.1130/2007.2433(01).

Hamilton, W.B., 2011, Plate tectonics began in Neoproterozoic time, and plumes from deep mantle have never operated: Lithos, v. 123, p. 1-20, http://dx.doi.org/10.1016/j.lithos.2010.12.007.

Hannington, M.D., de Ronde, C.E.J., and Petersen, S., 2005, Sea-Floor tectonics and submarine hydrothermal systems, in Hedenquist, J.W., Thompson, J.F.H., Goldfarb, R.J., and Richards, J.P., eds., Economic Geology $100^{\text {th }}$ Anniversary Volume, Society of Economic Geologists, p. 111-141.

Hanski, E., Huhma, H., Rastas, P., and Kamenetsky, V.S., 2001, The Palaeoproterozoic komatiite-picrite association of Finnish Lapland: Journal of Petrology, v. 42, p. 855-876, http://dx.doi.org/10.1093/petrology/42.5.855.

Hanski, E.J., and Smolkin, V.F., 1989, Pechenga ferropicrites and other early Proterozoic picrites in the eastern part of the Baltic Shield: Precambrian Research, v. 45, p. 63-82, http://dx.doi.org/10.1016/0301-9268(89)90031-4.
Hargraves, R.B., 1976, Precambrian Geologic History: Science, v. 193, p. 363-371, http://dx.doi.org/10.1126/science.193.4251.363.

Hart, T.R., 1984, The geochemistry and petrogenesis of a metavolcanic and intrusive sequence in the Kamiskotia area; Timmins, Ontario: Unpublished MSc thesis, University of Toronto, Toronto, ON, $179 \mathrm{p}$.

Hart, T.R., Gibson, H.L., and Lesher, C.M., 2004, Trace element geochemistry and petrogenesis of felsic volcanic rocks associated with volcanogenic massive $\mathrm{Cu}-\mathrm{Zn}-\mathrm{Pb}$ sulfide deposits: Economic Geology, v. 99, p. 1003-1013, http://dx.doi.org/10.2113/gsecongeo.99.5.1003.

Heather, K.B., 2001, The Geological Evolution of the Archean Swayze Greenstone Belt, Superior Province, Canada: Unpublished PhD thesis, Keele University, Keele, UK, 370 p

Helmstaedt, H., Padgham, W.A., and Brophy, J.A., 1986, Multiple dikes in Lower Kam Group, Yellowknife greenstone belt: Evidence for Archean sea-floor spreading?: Geology, v. 14, p. 562-566, http://dx.doi.org/10.1130/00917613(1986)14<562:MDILKG>2.0.CO;2

Henry, P., Stevenson, R.K., and Gariépy, C., 1998, Late Archean mantle composition and crustal growth in the western Superior Province of Canada: Neodymium and lead isotopic evidence from the Wawa, Quetico, and Wabigoon Subprovinces: Geochimica et Cosmochimica Acta, v. 62, p. 143-157, http://dx.doi.org/10.1016/S0016-7037(97)00324-4.

Herzberg, C., 1992, Depth and degree of melting of Komatiites: Journal of Geophysical Research, v. 97, p. 4521-4540, http://dx.doi.org/10.1029/91JB03066.

Hessler, A.M., and Lowe, D.R., 2006, Weathering and sediment generation in the Archean: An integrated study of the evolution of siliciclastic sedimentary rocks of the 3.2 Ga Moodies Group, Barberton Greenstone Belt, South Africa: Precambrian Research, v. 151, p. 185-210, http://dx.doi.org/10.1016/j.precamres.2006.08.008

Hildreth, W., 1981, Gradients in silicic magma chambers: Implications for lithospheric magmatism: Journal of Geophysical Research, v. 86, p. 10153-10192, http://dx.doi.org/10.1029/JB086iB11p10153.

Hildreth, W., and Moorbath, S., 1988, Crustal contributions to arc magmatism in the Andes of Central Chile: Contributions to Mineralogy and Petrology, v. 98, p. 455-489, http://dx.doi.org/10.1007/BF00372365.

Hill, R.E.T., 2001, Komatiite volcanology, volcanological setting and primary geochemical properties of komatiite-associated nickel deposits: Geochemistry: Exploration, Environment, Analysis, v. 1, p. 365-381, http://dx.doi.org/ 10.1144/geochem.1.4.365.

Hill, R.E.T., Barnes, S.J., Perring, C.S., Gole, M.J., and Dowling, S.E., 1994, The physical volcanology of komatiites in the Archaean Yilgarn Block, Western Australia: Australian research on Ore genesis symposium, Proceedings, Australian Mineral Foundation, Glenside, South Australia, AU, p. 4.1-4.5.

Hoffman, P.F., and Ranalli, G., 1988, Archean oceanic flake tectonics: Geophysical Research Letters, v. 15, p. 1077-1080, http://dx.doi.org/10.1029/ GL015i010p01077.

Hoffmann, J.E., Münker, C., Næraa, T., Rosing, M.T., Herwartz, D., Garbe-Schönberg, D., and Svahnberg, H., 2011, Mechanisms of Archean crust formation inferred from high-precision HFSE systematics in TTGs: Geochimica et Cosmochimica Acta, v. 75, p. 4157-4178, http://dx.doi.org/10.1016/ j.gca.2011.04.027.

Hofmann, A.W., 1988, Chemical differentiation of the Earth: The relationship between mantle, continental crust, and oceanic crust: Earth and Planetary Science Letters, v. 90, p. 297-314, http://dx.doi.org/10.1016/0012$821 \mathrm{X}(88) 90132-\mathrm{X}$

Hofmann, H.J., and Masson, M., 1994, Archean stromatolites from Abitibi greenstone belt, Quebec, Canada: Geological Society of America Bulletin, v. 106, p. 424-429, http://dx.doi.org/10.1130/0016-7606(1994)106<0424:ASFAGB > 2.3.CO;2.

Hofmann, H.J., Sage, R.P., and Berdusco, E.N., 1991, Archean Stromatolites in Michipicoten Group siderite ore at Wawa, Ontario: Economic Geology, v. 86, p. 1023-1030, http://dx.doi.org/10.2113/gsecongeo.86.5.1023.

Hofmann, H.J., Thurston, P.C., and Wallace, H., 1985, Archean stromatolites from Uchi greenstone belt, northwestern Ontario, in Ayres, L.D., Thurston, P.C., Card, K.D., and Weber, W., eds., Evolution of Archean Supracrustal sequences: Geological Association of Canada, Special Paper 28, p. 125-132.

Hollings, P., 2002, Archean Nb-enriched basalts in the northern Superior Province: Lithos, v. 64, p. 1-14, http://dx.doi.org/10.1016/S0024-4937(02)00154-8.

Hollings, P., and Kerrich, R., 1999, Trace element systematics of ultramafic and mafic volcanic rocks from the $3 \mathrm{Ga}$ North Caribou greenstone belt, northwestern Superior Province: Precambrian Research, v. 93, p. 257-279, http://dx.doi.org/10.1016/S0301-9268(98)00088-6.

Hollings, P., and Kerrich, R., 2000, An Archean arc basalt-Nb-enriched basalt-adakite association: the $2.7 \mathrm{Ga}$ Confederation assemblage of the Birch-Uchi greenstone belt: Contributions to Mineralogy and Petrology, v. 139, p. 208-226, http://dx.doi.org/10.1007/PL00007672.

Hollings, P., and Wyman, D., 1999, Trace element and Sm-Nd systematics of vol- 
canic and intrusive rocks from the $3 \mathrm{Ga}$ Lumby Lake Greenstone belt, Superior Province: evidence for Archean plume-arc interaction: Lithos, v. 46, p. 189-213, http://dx.doi.org/10.1016/S0024-4937(98)00062-0.

Hollings, P., Wyman D., and Kerrich, R., 1999, Komatiite-basalt-rhyolite volcanic associations in northern Superior Province greenstone belts: significance of plume-arc interaction in the generation of the proto-continental Superior Province: Lithos, v. 46, p. 137-161, http://dx.doi.org/10.1016/S00244937(98)00058-9.

Hollings, P., Stott, G., and Wyman, D., 2000, Trace element geochemistry of the Meen-Dempster greenstone belt, Uchi subprovince, Superior Province, Canada: back-arc development on the margins of an Archean protocontinent: Canadian Journal of Earth Sciences, v. 37, p. 1021-1038, http://dx.doi.org/ 10.1139/e00-007.

Hooper, P.R., Binger, G.B., and Lees, K.R., 2002, Ages of the Steens and Columbia River flood basalts and their relationship to extension-related calc-alkalic volcanism in eastern Oregon: Geological Society of America Bulletin, v. 114, p. 43-50, http://dx.doi.org/10.1130/0016-7606(2002)114<0043:AOTSAC> 2.0.CO;2.

Houlé, M., Lesher, C.M., Gibson, H.L., Fowler, A.D., and Sproule, R.A., 2001, Physical volcanology of komatiites in the Abitibi Greenstone Belt: Ontario Geological Survey, Summary of Field Work and other Activities, Open File Report 6070 , p. $13-11$ to $13-17$

Houlé, M., Gibson, H.L., Lesher, C.M., Davis, P.C., Cas, R.A.F., Beresford, S.W., and Arndt, N.T., 2008a, Komatiitic Sills and Multi-Generational Peperite at Dundonald Beach, Abitibi Greenstone Belt, Ontario: Volcanic architecture and nickel sulfide distribution: Economic Geology, v. 103, p. 1269-1284, http://dx.doi.org/10.2113/gsecongeo.103.6.1269.

Houlé, M.G., Ayer, J.A., Baldwin, G., Berger, B., Dinel, E., Fowler, A.D., Moulton, B., Saumur, B.-M., and Thurston, P., 2008b, Stratigraphy and volcanology of supracrustal assemblages hosting base metal and gold mineralization in the Abitibi Greenstone Belt: Geological Association of Canada, Mineralogical Association of Canada, Field Trip B4, Quebec, 84 p.

Houlé, M.G., Préfontaine, S., Fowler, A.D., and Gibson, H.L., 2009, Endogenous growth in channelized komatiite lava flows: evidence from spinifex-textured sills at Pyke Hill and Serpentine Mountain, Western Abitibi Greenstone Belt, Northeastern Ontario, Canada: Bulletin of Volcanology, v. 71, p. 881-901, http://dx.doi.org/10.1007/s00445-009-0273-y.

Houlé, M.C., Lesher, C.M., Metsaranta, R.T., Goutier, J., Gilbert, H.P., and McNicoll, V., 2012, Temporal and spatial distribution of magmatic Ni, Cu, PGE, Cr and Fe,Ti, V deposits in the Bird River-Uchi-Oxford Stull, La Grande Eastmain superdomain: A new metallotect within the Superior Province: Society for Geology Applied to Minerals, 12th SGA Biennial Meeting, Uppsala, Sweden, p. 1009-1012.

Hrabi, R.B., and Cruden, A.R., 2006, Structure of the Archean English River subprovince; implications for the tectonic evolution of the western Superior Province, Canada: Canadian Journal of Earth Sciences, v. 43, p. 947-966, http://dx.doi.org/10.1139/e06-023.

Hudak, G.J., Morton, R.L., Franklin, J.M., and Peterson, D.M., 2003, Morphology, distribution, and estimated eruption volumes for intracaldera tuffs associated with volcanic-hosted massive sulfide deposits in the Archean Sturgeon Lake Caldera Complex, northwestern Ontario, in White, J.D.L., Smellie, J.L., and Clagur, D.A., eds., Explosive Subaqueous Volcanism: American Geophysical Union, Monograph 140, p. 345-360, http://dx.doi.org/10.1029/140gm23.

Hunter, D.R., and Stowe, C.W., 1997, A historical review of the origin, composition, and setting of Archaean greenstone belts (pre-1980): Oxford Monographs on Geology and Geophysics, v. 35, p. 5-30.

Ishikawa, Y., Sawaguchi, T., Iwaya, S., and Horiuchi, M., 1976, Delineation of prospecting targets for Kuroko deposits based on modes of volcanism of underlying dacite and alteration halos: Mining Geology, v. 26, p. 105-117.

Jackson, S.L., and Fyon, J.A., 1991, The Western Abitibi Subprovince in Ontario, in Thurston, P.C., Williams, H.R., Sutcliffe, R.H., and Stott, G.M., eds., Geology of Ontario: Ontario Geological Survey, Special Volume 4, Pt. 1, p. 405-482.

Jahn, B.M., 1997, Géochimie des granitoïdes archéens et de la croûte primitive, in Hagemann, R., and Treuil, M., eds., Introduction à la géochimie et ses applications: Commissariat a l'énergie atomique, Université Pierre et Marie Curie, Paris.

Jelsma, H.A., van der Beek, P.A., and Vinyu, M.L., 1993, Tectonic evolution of the Bindura-Shamva greenstone belt (northern Zimbabwe): Progressive deformation around diapiric batholiths: Journal of Structural Geology, v. 15, p. 163-176, http://dx.doi.org/10.1016/0191-8141(93)90093-P.

Jensen, L.S., 1985, Stratigraphy and Petrogenesis of Archean Metavolcanic Sequences, Southwestern Abitibi subprovince, Ontario, in Ayres, L.D., Thurston, P.C., Card, K.D., and Weber, W., eds., Evolution of Archean supracrustal Sequences: Geological Association of Canada, Special paper 28, p. 65-87.

Johnson, T.E., Brown, M., Kaus, B.J.P., and Van'Tongeren, J.A., 2014, Delamination and recycling of Archaean crust caused by gravitational instabilities: Nature
Geoscience, v. 7, p. 47-52, http://dx.doi.org/10.1038/ngeo2019.

Jolly, W.T., 1978, Metamorphic history of the Archean Abitibi Belt, in Fraser, J.A., and Heywood, W.W., eds., Metamorphism in the Canadian Shield: Geological Survey of Canada, Paper 78-10, p. 63-78.

Kamber, B.S., 2010, Archean mafic-ultramafic volcanic landmasses and their effect on ocean-atmosphere chemistry: Chemical Geology, v. 274, p. 19-28, http://dx.doi.org/10.1016/j.chemgeo.2010.03.009.

Kamber, B.S., 2015, The evolving nature of terrestrial crust from the Hadean, through the Archaean, into the Proterozoic: Precambrian Research, v. 258, p. 48-82, http://dx.doi.org/10.1016/j.precamres.2014.12.007.

Kamber, B.S., Bolhar, R., and Webb, G.E., 2004, Geochemistry of late Archaean stromatolites from Zimbabwe: evidence for microbial life in restricted epicontinental seas: Precambrian Research, v. 132, p. 379-399, http://dx.doi.org/ 10.1016/j.precamres.2004.03.006.

Katz, L.R., Kontak, D., Dubé, B., and McNicoll, V.J., 2015, The Archean Côté gold intrusion-related $\mathrm{Au}(-\mathrm{Cu})$ deposit, Ontario: a large tonnage, low-grade deposit centered on a magmatic-hydrothermal breccia, in Dubé, B., and MercierLangevin, P., eds., Targeted Geoscience Initiative 4: Contributions to the understanding of Archean lode gold deposits and implications for exploration: Geological Survey of Canada Open File Report 7852, p. 139-155.

Keleman, P.B., 1995, Genesis of high Mg\# andesites and the continental crust: Contributions to Mineralogy and Petrology, v. 120, p. 1-19, http://dx.doi.org/ 10.1007/BF00311004

Kepezhinskas, P.K., Defant, M.J., and Drummond, M.S., 1995, Na-metasomatism in the island-arc mantle by slab melt-peridotite interaction: Evidence from mantle xenoliths in the North Kamchatka arc: Journal of Petrology, v. 36, p. 1505-1527.

Kerr, A.C., Marriner, G.F., Arndt, N.T., Tarney, J., Nivia, A., Saunders, A.D., and Duncan, R.A., 1996, The petrogenesis of Gorgona komatiites, picrites and basalts: new field, petrographic and geochemical constraints: Lithos, v. 37, p. 245-260, http://dx.doi.org/10.1016/0024-4937(95)00039-9.

Kerrich, R., and Fryer, B.J., 1979, Archean precious-metal hydrothermal systems, Dome Mine, Abitibi greenstone belt: II. REE and oxygen isotope relations: Canadian Journal of Earth Sciences, v. 16, p. 440-458, http://dx.doi.org/ $10.1139 /$ e79-041.

Kerrich, R., and Manikyamba, C., 2012, Contemporaneous eruption of Nb-enriched basalts - K-adakites - Na-adakites from the $2.7 \mathrm{Ga}$ Penakacherla terrane: Implications for subduction zone processes and crustal growth in the eastern Dharwar craton, India: Canadian Journal of Earth Sciences, v. 49, p. 615-636, http://dx.doi.org/10.1139/e2012-005.

Kerrich, R., and Wyman, D.A., 1996, The trace element systematics of igneous rocks in mineral exploration: An overview, in Wyman, D.A., ed., Trace Element Geochemistry of Volcanic Rocks: Applications for Massive Sulphide Exploration: Geological Association of Canada, Short Course Notes 12, p. 1-50.

Kerrich, R., Wyamn, D., Fan, J., and Bleeker, W., 1998, Boninite series: low Ti-tholeiite associations from the $2.7 \mathrm{Ga}$ Abitibi greenstone belt: Earth and Planetary Science Letters, v. 164, p. 303-316, http://dx.doi.org/10.1016/S0012821X(98)00223-4

Kerrich, R., Polat, A., Wyman, D., and Hollings, P., 1999, Trace element systematics of $\mathrm{Mg}$ - to Fe-tholeiitic basalt suites of the Superior Province: implications for mantle reservoirs and greenstone belt genesis: Lithos, v. 46, p. 163-187, http:/ /dx.doi.org/10.1016/S0024-4937(98)00059-0.

Ketchum, J.W.F., Ayer, J.A., van Breemen, O., Pearson, N.J., and Becker, J.K., 2008, Pericontinental crustal growth of the southwestern Abitibi Subprovince, Canada - U-Pb, Hf, and Nd isotopic evidence: Economic Geology, v. 103, p. 1151-1184.

Kiyokawa, S., and Taira, A., 1998, The Cleaverville Group in the West Pilbara Coastal Granitoid-Greenstone terrain of Western Australia: an example of a Mid-Archaean immature oceanic island-arc succession: Precambrian Research, v. 88, p. 109-142, http://dx.doi.org/10.1016/S0301-9268(97)00066-1.

Komiva, T., Hayashi, M., Maruyama, S., and Yurimoto, H., 2002, Intermediate-P/T type Archean metamorphism of the Isua supracrustal belt: Implications for secular change of geothermal gradients at subduction zones and for Archean plate tectonics: American Journal of Science, v. 302, p. 806-826, http://dx.doi.org/ 10.2475/ajs.302.9.806

Korja, A., Lahtinen, R., Heikkinen, P., Kukkonen, I.T., Ekdahl, E., Nironen, M. Kontinen, A., Paavola, J., Lukkarinen, H., Ruotsalainen, A., Lehtimaki, J., Forss H., Lanne, E., Salmirinne, H., Pernu, T., Turunen, P., Ruokanen, E., Tiira, T., Keskinen, J., Hjelt, S.-E., Tiikkainen, J., Yliniemi, J., Jalkanen, E., Berzin, R., Suleimanov, A., Zamoshnyaya, N., Moissa, I., Kostyuk, A., and Litvinenko, V. 2006, A geological interpretation of the upper crust along FIRE 1: Geological Survey of Finland, Special Paper 43, p. 45-76.

Kositcin, N., Brown, S.J.A., Barley, M.E., Krapež, B., Cassidy, K.F., and Champion, D.C., 2008, SHRIMP U-Pb zircon age constraints on the Late Archaean tectonostratigraphic architecture of the Eastern Goldfields Superterrane, Yilgarn Craton, Western Australia: Precambrian Research, v. 161, p. 5-33, 
http://dx.doi.org/10.1016/j.precamres.2007.06.018.

Kozhevnikov, V.N., 1992, Ggeology and geochemistry of Archean greenstone structures in North Karelia (in Russian): Karelian Branch Russian Academy of Sciences, Petrozavodsk, 199 p.

Krapez, B., and Barley, M.E., 1987, Archaean strike-slip faulting and related ensialic basins: evidence from the Pilbara Block, Australia: Geological Magazine, v. 124, p. 555-567, http://dx.doi.org/10.1017/S0016756800017386.

Krapez, B., and Eisenlohr, B., 1998, Tectonic settings of Archaean (3325-2775 Ma) crustal-supracrustal belts in the West Pilbara Block: Precambrian Research, v. 88, p. 173-205, http://dx.doi.org/10.1016/S0301-9268(97)00068-5.

Krogh, T.E., and Davis, G.L., 1971, Zircon U-Pb Ages of Archean Metavolcanic Rocks in the Canadian Shield: Carnegie Institution of Washington Yearbook 70, p. 241-242.

Kröner, A., 1991, Tectonic evolution in the Archaean and Proterozoic: Tectonophysics, v. 187, p. 393-410, http://dx.doi.org/10.1016/0040-1951(91)90478-B.

Kuiper, D., 2010, Geology, geochemistry and geochronology of the Dufault, Séguin, and Horseshoe gabbroic-dioritic intrusions, Blake River Group (2704-2695 $\mathrm{Ma})$, Abitibi Subprovince, Québec: Unpublished MSc thesis, Laurentian University, $\mathrm{ON}, 88 \mathrm{p}$.

Kusky, T.M., 1998, Tectonic setting and terrane accretion of the Archean Zimbabwe craton: Geology, v. 26, p. 163-166, http://dx.doi.org/10.1130/0091 7613(1998)026<0163:TSATAO > 2.3.CO;2

Kusky, T.M., and Kidd, W.S.F., 1992, Remants of an Archean oceanic plateau, Belingwe greenstone belt, Zimbabwe: Geology, v. 20, p. 43-46, http://dx.doi.org/10.1130/0091-7613(1992)020<0043:ROAAOP>2.3.CO;2.

Kusky, T.M., and Polat, A., 1999, Growth of granite-greenstone terranes at convergent margins, and stabilization of Archean cratons: Tectonophysics, v. 305, p. 43-73, http://dx.doi.org/10.1016/S0040-1951(99)00014-1.

Kusky, T.M., Li, J.-H., and Tucker, R.D., 2001, The Archean Dongwanzi Ophiolite Complex, North China Craton: 2.505-Billion-Year-Old oceanic crust and mantle: Science, v. 292, p. 1142-1145, http://dx.doi.org/10.1126/science.1059426.

Laflèche, M.R., Dupuy, C., and Bougault, H., 1992, Geochemistry and petrogenesis of Archean mafic volcanic rocks of the southern Abitibi Belt, Québec: Precambrian Research, v. 57, p. 207-241, http://dx.doi.org/10.1016/03019268(92)90003-7.

Lafrance, B., Mueller, W.U., Daigneault, R., and Dupras, N., 2000, Evolution of a submerged composite arc volcano: volcanology and geochemistry of the Normétal volcanic complex, Abitibi greenstone belt, Québec, Canada: Precambrian Research, v. 101, p. 277-311, http://dx.doi.org/10.1016/S03019268(99)00092-3.

Lambert, M.B., Burbidge, G., Jefferson, C.W., Beaumont-Smith, C., and Lustwerk, R., 1990, Stratigraphy, facies and structure in volcanic and sedimentary rocks of the Archean Back River volcanic complex, NWT: Geological Survey of Canada, Current Research Paper 90-1C, p. 151-165, http://dx.doi.org/ $10.4095 / 131253$.

Lambert, M.B., Ernst, R.E., and Dudás, F.O.L., 1992, Archean mafic dyke swarms near the Cameron River and Beaulieu River volcanic belts and their implications for tectonic modelling of the Slave Province, Northwest Territories: Canadian Journal of Earth Sciences, v. 29, p. 2226-2248, http://dx.doi.org/10.1139/e92176.

Langford, F.F., and Morin, J.A., 1976, The development of the Superior Province of northwestern Ontario by merging island arcs: American Journal of Science, v. 276, p. 1023-1034, http://dx.doi.org/10.2475/ajs.276.9.1023.

Larbi, Y., Stevenson, R., Breaks, F., Machado, N., and Gariépy, C., 1999, Age and Isotopic composition of late Archean leucogranites: implications for continental collision in the western Superior Province: Canadian Journal of Earth Sciences, v. 36, p. 495-510, http://dx.doi.org/10.1139/e98-113.

Large, R.R., Gemmell, J.B., Paulick, H., and Huston, D.L., 2001, The alteration box plot: a simple approach to understanding the relationship between alteration mineralogy and lithogeochemistry associated with volcanic-hosted massive sulfide deposits: Economic Geology, v. 96, p. 957-971, http://dx.doi.org/ 10.2113/gsecongeo.96.5.957.

Large, R.R., Bull, S.W., and Maslennikov, V.V., 2011, A carbonaceous sedimentary source-rock model for Carlin-type and orogenic gold deposits: Economic Geology, v. 106, p. 331-358, http://dx.doi.org/10.2113/econgeo.106.3.331

Larson, J.E., and Hutchinson, R.W., 1993, Selbaie Zn-Cu-Ag deposits, Quebec, Canada. An example of evolution from subaqueous to subaerial volcanism and mineralization in an archean caldera environment: Economic Geology, v. 88, p. 1460-1460, http://dx.doi.org/10.2113/gsecongeo.88.6.1460

Laurent, O., Martin, H., Moyen, J.F., and Doucelance, R., 2014, The diversity and evolution of late-Archean granitoids: Evidence for the onset of "modern-style" plate tectonics between 3.0 and 2.5 Ga: Lithos, v. 205, p. 208-235, http://dx.doi.org/10.1016/j.lithos.2014.06.012.

Layer, P.W., Kröner, A., McWilliams, M., and York, D., 1989, Elements of the Archean thermal history and apparent polar wander of the eastern Kaapvaal Craton, Swaziland, from single grain dating and paleomagnetism: Earth and
Planetary Science Letters, v. 93, p. 23-34, http://dx.doi.org/10.1016/0012$821 \mathrm{X}(89) 90181-7$

Le Maitre, R.W., editor, 1989, A Classification of igneous rocks and glossary of terms: Recommendations of the International Union of Geological Sciences subcommission on the systematics of Igneous Rocks: Blackwell Scientific Publishing, Oxford, v. 193.

Leclerc, F., Bédard, J.H., Harris, L.B., McNicoll, V.J., Goulet, N., Roy, P., and Houlé, P., 2011, Tholeiitic to calc-alkaline cyclic volcanism in the Roy Group, Chibougamau area, Abitibi Greenstone Belt — revised stratigraphy and implications for VHMS exploration: Canadian Journal of Earth Sciences, v. 48, p. 661-694, http://dx.doi.org/10.1139/E10-088.

Legault, M., Gauthier, M., Jébrak, M., Davis, D.W., and Baillargeon, F., 2002, Evolution of the subaqueous to near-emergent Joutel volcanic complex, Northern Volcanic zone, Abitibi subprovince, Quebec, Canada: Precambrian Research, v. 115, p. 187-221, http://dx.doi.org/10.1016/S0301-9268(02)00010-4

Lentz, D.R., 1998, Mineralized intrusion-related skarn systems: Mineralogical Association of Canada, Ottawa, ON, Canada, Short Course Handbook, 664 p.

Lesher, C.M., 1989, Komatiite-associated nickel sulfide deposits: Reviews in Economic Geology, v. 4, p. 44-101.

Lesher, C.M., 2007, Ni-Cu-(PGE) Deposits in the Raglan Area, Cape Smith Belt, New Quebec, in Goodfellow, W., ed., Mineral Deposits of Canada: A Synthesis of Major Deposit-types, District Metallogeny, the Evolution of Geological Provinces, and Exploration Methods: Geological Association of Canada, Mineral Deposits Division, Special Publication 5, p. 351-385.

Lesher, C.M., and Keays, R.R., 2002, Komatiite-associated Ni-Cu-(PGE) deposits; geology, mineralogy, geochemistry and genesis, in Cabri, L.J., ed., The geology, geochemistry, mineralogy and mineral beneficiation of platinum-group elements: Canadian Institute of Mining and Metallurgy, p. 579-617.

Lesher, C.M., Goodwin, A.M., Campbell I.H., and Gorton, M.P., 1986, Trace-element geochemistry of ore-associated and barren, felsic metavolcanic rocks in the Superior Province, Canada: Canadian Journal of Earth Sciences, v. 23, p. 222-237, http://dx.doi.org/10.1139/e86-025.

Lodge, R.W.D., Gibson, H.L., Stott, G.M., Hudak, G.J., Jirsa, M.A., and Hamilton, M.A., 2013, New U-Pb geochronology from Timiskaming-type assemblages in the Shebandowan and Vermilion greenstone belts, Wawa subprovince, Superior Craton: Implications for the Neoarchean development of the southwestern Superior Province: Precambrian Research, v. 235, p. 264-277, http://dx.doi.org/10.1016/j.precamres.2013.06.011.

London, D., and Morgan, G.B.,VI, 2012, The pegmatite puzzle: Elements, v. 8, p. 263-268, http://dx.doi.org/10.2113/gselements.8.4.263.

Lowe, D.R., Byerly, G.R., and Heubeck, C., 1999, Structural divisions and development of the west-central part of the Barberton Greenstone Belt, in Lowe, D.R., and Byerly, G.R., eds., Geologic Evolution of the Barberton Greenstone Belt, South Africa: Geological Society of America, Special Papers, v. 329, p. 37-82, http://dx.doi.org/10.1130/0-8137-2329-9.37.

Lucas, S.B., Stern, R.A., Syme, E.C., Reilly, B.A., and Thomas, D.J., 1996, Intraoceanic tectonics and the development of continental crust: 1.92-1.84 Ga evolution of the Flin Flon belt, Canada: Geological Society of America Bulletin, v. 108, p. 602-629, http://dx.doi.org/10.1130/0016-7606(1996)108<0602:ITAT$\mathrm{DO}>2.3 . \mathrm{CO} ; 2$.

Ludden, J., Hubert, C., and Gariépy, C., 1986, The tectonic evolution of the Abitibi greenstone belt of Canada: Geological Magazine, v. 123, p. 153-166, http://dx.doi.org/10.1017/S0016756800029800.

Macgregor, A.M., 1951, Some milestones in the Precambrian of Southern Rhodesia [presidential address]: Proceedings of the Geological Society of South Africa, v. 54, p. $27-71$

Maier, W.D., Barnes, S.-J., and Pellet, T., 1996, The economic significance of the Bell River complex, Abitibi subprovince, Quebec: Canadian Journal of Earth Sciences, v. 33, p. 967-980, http://dx.doi.org/10.1139/e96-073.

Manikyamba, C., and Naqvi, S.M., 1998, Archaean oceanic ridge and floor basalt: an example and implications from Sandur greenstone belt, Dharwar Craton: Geological Survey of Finland, Special Paper 26, 36 p.

Manikyamba, C., Naqvi, S.M., Subba Rao, D.V., Ram Mohan, M., Khanna, T.C., Rao, T.G., and Reddy, G.L.N., 2005, Boninites from the Neoarchaean Gadwal Greenstone belt, Eastern Dharwar Craton, India: Implications for Archaean subduction processes: Earth and Planetary Science Letters, v. 230, p. 65-83, http://dx.doi.org/10.1016/j.epsl.2004.06.023.

Manikyamba, C., Kerrich, R., Khanna, T.C., Satyanarayanan, M., and Krishna, A. K., 2009, Enriched and depleted arc basalts, with Mg-andesites and adakites; A potential paired arc-back-arc of the $2.6 \mathrm{Ga}$ Hutti greenstone terrane, India: Geochimica et Cosmochimica Acta, v. 73, p. 1711-1736, http://dx.doi.org/ 10.1016/j.gca.2008.12.020

Manikyamba, C., Kerrich, R., Polat, A., Raju, K., Satyanarayanan, M., and Krishna, A.K., 2012, Arc picrite-potassic adakitic-shoshonitic volcanic association of the Neoarchean Sigegudda greenstone terrane, western Dharwar craton: Transition from arc wedge to lithosphere melting: Precambrian Research, v. 212-213, p. 
207-224, http://dx.doi.org/10.1016/j.precamres.2012.05.006.

Martin, A., Nisbet, E.G., Bickle, M.J., and Orpen, J.L., 1993, Rock units and stratigraphy of the Belingwe greenstone belt: the complexity of the tectonic setting, in Bickle, M.J., and Nisbet, E.G., eds., The Geology of the Belingwe Greenstone Belt, Zimbabwe: A study of the Evolution of Archaean Continental Crust: A.A. Balkema, Rotterdam, p. 13-37.

Martin, H., 1987, Evolution in compositon of granitic rocks controlled by timedependent changes in petrogenetic processes: Examples from the Archaean of eastern Finland: Precambrian Research, v. 35, p. 257-276, http://dx.doi.org/ 10.1016/0301-9268(87)90058-1.

Martin, H., 1993, The mechanisms of petrogenesis of the Archeaean continental crust-Comparison with modern processes: Lithos, v. 30, p. 373-388, http://dx.doi.org/10.1016/0024-4937(93)90046-F.

Martin, H., 1999, Adakitic magmas: modern analogues of Archaean granitoids, Lithos, v. 46, p. 411-429, http://dx.doi.org/10.1016/S0024-4937(98)00076-0.

Martin, H., Smithies, R.H., Rapp, R., Moyen, J.-F., and Champion, D., 2005, An overview of adakite, tonalite-trondhjemite-granodiorite (TTG), and sanukitoid relationships and some implications for crustal evolution: Lithos, v. 79, p. 1-24, http://dx.doi.org/10.1016/j.lithos.2004.04.048.

Maurice, C., David, J., Bédard, J.H., and Francis, D., 2009, Evidence for a widespread mafic cover sequence and its implications for continental growth in the Northeastern Superior Province: Precambrian Research, v. 168, p. 45-65, http://dx.doi.org/10.1016/j.precamres.2008.04.010

McCall, G.J.H., 2003, A critique of the analogy between Archaean and Phanerozoic tectonics based on regional mapping of the Mesozoic-Cenozoic plate convergent zone in the Makran, Iran: Precambrian Research, v. 127, p. 5-17, http://dx.doi.org/10.1016/S0301-9268(03)00178-5

McCarron, J.J., and Smellie, J.L., 1998, Tectonic implications of fore-arc magmatism and generation of high-magnesian andesites: Alexander Island, Antarctica: Journal of the Geological Society, v. 155, p. 269-280, http://dx.doi.org/ 10.1144/gsigs.155.2.0269.

McCulloch, M.T., and Gamble, J.A., 1991, Geochemical and geodynamical constraints on subduction zone magmatism: Earth and Planetary Science Letters, v. 102, p. 358-374, http://dx.doi.org/10.1016/0012-821X(91)90029-H.

McDonough, W.F., and Ireland, T.R., 1993, Intraplate origin of komatiites inferred from trace elements in glass inclusions: Nature, v. 365, p. 432-434, http:/ /dx.doi.org/10.1038/365432a0.

Migdisov, A.A., Bredanova, N.V., Rozen, O.M., and Abbyasov, A.A., 2003, Evolution of the mineral composition of pelitic and psammitic rocks in the geologic history of continents: Geochemistry International, v. 41, p. 959-978.

Miyashiro, A., 1973, Paired and unpaired metamorphic belts: Tectonophysics, v. 17, p. 241-254, http://dx.doi.org/10.1016/0040-1951(73)90005-X.

Morin, J.A., 1973, Geology of the Lower Shebandowan Lake area, District of Thunder Bay: Ontario Department of Mines, Geological Report 110, 45 p.

Morris, J.D., and Hart, S.R., 1983, Isotopic and incompatible element constraints on the genesis of island arc volcanics from Cold Bay and Amak Island, Aleutians, and implications for mantle structure: Geochimica et Cosmochimica Acta, v. 47 p. 2015-2030, http://dx.doi.org/10.1016/0016-7037(83)90217-X.

Mortensen, J.K., 1993, U-Pb Geochronology of the eastern Abitibi Subprovince. Part 2: Noranda - Kirkland Lake area: Canadian Journal of Earth Sciences, v. 30, p. 29-41, http://dx.doi.org/10.1139/e93-003.

Morton, R.L., Walker, J.S., Hudak, G.J., and Franklin, J.M., 1991, The early development of an Archean submarine caldera complex with emphasis on the Mattabi ash-flow tuff and its relationship to the Mattabi massive sulfide deposit: Economic Geology, v. 86, p. 1002-1011, http://dx.doi.org/10.2113/gsecongeo.86.5.1002.

Moyen, J.-F., and Stevens, G., 2006, Experimental constraints on TTG petrogenesis: Implications for Archean geodynamics, in Benn, K., Mareschal, J.-C., and Condie, K.C., eds., American Geophysical Union, Monograph 164, p. 149-175, http://dx.doi.org/10.1029/164gm11.

Mueller, W., and Corcoran, P.L., 1998, Late-orogenic basins in the Archean Superior Province, Canada: characteristics and inferences: Sedimentary Geology, v. 120, p. 177-203, http://dx.doi.org/10.1016/S0037-0738(98)00032-3.

Mueller, W., and Corcoran, P.L., 2001, Volcano-sedimentary processes operating on a marginal continental arc: the Archean Raquette Lake Formation, Slave Province, Canada: Sedimentary Geology, v. 141-142, p. 169-196, http://dx.doi.org/10.1016/S0037-0738(01)00074-4

Mueller, W., and Dimroth, E., 1987, A terrestrial-shallow marine transition in the Archean Opemisca Group east of Chapais, Quebec: Precambrian Research, v 37, p. 29-55, http://dx.doi.org/10.1016/0301-9268(87)90038-6.

Mueller, W., and Pickett, C., 2005, Relative sea level change along the Slave craton coastline: Characteristics of Archean continental rifting: Sedimentary Geology, v. 176, p. 97-119, http://dx.doi.org/10.1016/j.sedgeo.2004.12.015.

Mungall, J.E., Harvey, J.D., Balch, S.J., Azar, B., Atkinson, J., and Hamilton, M.A., 2010, Eagle's Nest: A magmatic Ni-Cu-PGE deposit in the James Bay Lowlands, Ontario, Canada: Society of Economic Geologists, Special Publication, v.
15 , p. $539-557$.

Myers, J.S., and Swager, C., 1997, The Yilgarn Craton, Australia, in de Wit, M.J., and Ashwal, L.D., eds., Greenstone Belts: Clarendon Press, Oxford, p. 640-656.

Naqvi, S.M., 2008, Geochemical indicators of the Neoarchaean subduction-accretion related magmatism: a global perspective with special reference to the Dharwar Craton: Geological Society of India, Memoir, v. 73, p. 1-20.

Naqvi, S.M., Khan, R.M.K., Manikyamba, C., Mohan, M.R., and Khanna, T.C., 2006, Geochemistry of the NeoArchaean high-Mg basalts, boninites and adakites from the Kushtagi-Hungund greenstone belt of the Eastern Dharwar craton (EDC): implications for the tectonic setting: Journal of Asian Earth Sciences, v. 27, p. 25-44, http://dx.doi.org/10.1016/j.jseaes.2005.01.006.

Nehring, F., Foley, S.F., Höltta, P., and Van Den Kerkhof, A.M., 2009, Internal differentiation of the Archean continental crust: Fluid-controlled partial melting of granulites and TTG - Amphibolite associations in Central Finland: Journal of Petrology, v. 50, p. 3-35, http://dx.doi.org/10.1093/petrology/egn070.

O’Neil, J., Maurice, C., Stevenson, R.K., Larocque, J., Cloquet, C., David, J., and Francis, D., 2008, The Geology of the 3.8 Ga Nuvvuagittuq (Porpoise Cove) Greenstone Belt, Northeastern Superior Province, Canada, in Van Kranendonk, M.J., Smithies, R.H., and Bennett, V.C., eds., Earth's Oldest Rocks: Elsevier, Amsterdam, p. 219-250.

Ojakangas, R.W., 1985, Review of Archean clastic sedimentation, Canadian shield: major felsic volcanic contributions to turbidite and alluvial fan-fluvial facies associations, in Ayres, L.D., Thurston, P.C., Card, K.D., and Weber, W., eds., Evolution of Archean Supracrustal Sequences: Geological Association of Canada, Special Paper 28, p. 23-47.

Othman, D.B., Arndt, N.T., White, W.M., and Jochum, K.P., 1990, Geochemistry and age of Timiskaming alkali volcanics and the Otto syenite stock, Abitibi, Ontario: Canadian Journal of Earth Sciences, v. 27, p. 1304-1311, http://dx.doi.org/10.1139/e90-140.

Palme, H., and Jones, A., 2004, Solar system abundances of the elements, in Holland, H.D., and Turekian, K.K., eds., Treatise on Geochemistry: Elsevier Amsterdam, p. $41-61$.

Parks, J., Lin, S., Davis, D., and Corkery, T., 2006, New high-precision U-Pb ages for the Island Lake greenstone belt, northwestern Superior Province: implications for regional stratigraphy and the extent of the North Caribou terrane: Canadian Journal of Earth Sciences, v. 43, p. 789-803, http://dx.doi.org/10.1139/ e06-044.

Parman, S.W., Grove, T.L., and Dann, J.C., 2001, The production of Barberton komatiites in an Archean subduction zone: Geophysical Research Letters, v. 28, p. 2513-2516, http://dx.doi.org/10.1029/2000GL012713.

Pawley, M.J., Van Kranendonk, M.J., and Collins, W.J., 2004, Interplay between deformation and magmatism during doming of the Archaean Shaw Grantioid Complex, Pilbara Craton, Western Australia: Precambrian Research, v. 131, p. 213-230, http://dx.doi.org/10.1016/j.precamres.2003.12.010.

Pearce, J.A., and Peate, D.W., 1995, Tectonic implications of the composition of volcanic arc magmas: Annual Review of Earth and Planetary Sciences, v. 23, p. $251-285$.

Perchuk, A.L., and Morgunova, A.A., 2014, Variable P-T paths and HP-UHP metamorphism in a Precambrian terrane, Gridino, Russia: Petrological evidence and geodynamic implications: Gondwana Research, v. 25, p. 614-629, http://dx.doi.org/10.1016/j.gr.2012.09.009

Percival, J.A., 2007, Geology and Metallogeny of the Superior Province, Canada, in Goodfellow, W., ed., Mineral Deposits of Canada: A Synthesis of Major Deposit Types, District Metallogeny, the Evolution of Geological Provinces and Exploration Methods: Geological Association of Canada, Mineral Deposits Division, Special Publication 5, p. 903-928.

Percival, J.A., and Helmstaedt, H., 2006, The western Superior Province Lithoprobe and NATMAP Transects: Introduction and summary: Canadian Journal of Earth Sciences, v. 43, p. 743-747, http://dx.doi.org/10.1139/e06-063.

Percival, J.A., and Stott, G.M., 2010, Superior Province: overview, update and reflections: Geological Survey of Western Australia, Record 2010/18, p. 4-6.

Percival, J.A., Stern, R.A., Skulski, T., Card, K.D., Mortensen, J.K., and Bégin, N.J., 1994, Minto Block, Superior Province: Missing link in deciphering assembly of the craton at 2.7 Ga: Geology, v. 22, p. 839-842, http://dx.doi.org/10.1130/ 0091-7613(1994)022<0839:MBSPML>2.3.CO;2

Percival, J.A., Stern, R.A., and Rayner, N., 2003, Archean adakites from the Ashuanipi complex, eastern Superior Province, Canada: geochemistry, geochronology and tectonic significance: Contributions to Mineralogy and Petrology, v. 145, p. 265-280, http://dx.doi.org/10.1007/s00410-003-0450-5.

Percival, J.A., Bleeker, W., Cook, F.A., Rivers, T., Ross, G., and van Staal, C.R., 2004 PanLITHOPROBE workshop IV: Intra-orogen correlations and comparative orogenic anatomy: Geoscience Canada, v. 31, p. 23-39.

Percival, J.A., Sanborn-Barrie, M., Skulski, T., Stott, G.M., Helmstaedt, H., and White, D.J., 2006, Tectonic evolution of the western Superior Province from NATMAP and Lithoprobe studies: Canadian Journal of Earth Sciences, v. 43 , p. 1085-1117, http://dx.doi.org/10.1139/e06-062. 
Perring, C.S., Barnes, S.J., and Hill, R.E.T., 1994, Direct evidence for thermal erosion and related nickel-sulfide mineralisation at the base of a komatiite lava channel: Exploration and Mining Research News 2, p. 7-11.

Peschler, A.P., Benn, K., and Roest, W.R., 2004, Insights on Archean continental geodynamics from gravity modelling of granite-greenstone terranes: Journal of Geodynamics, v. 38, p. 185-207, http://dx.doi.org/10.1016/j.jog.2004.06.005.

Pettigrew, N.T., and Hattori, K.H., 2006, The Quetico intrusions of western Superior Province: Neo-Archean examples of Alaskan/Ural-type mafic-ultramafic intrusions: Precambrian Research, v. 149, p. 21-42, http://dx.doi.org/10.1016/ j.precamres.2006.06.004.

Phinney, W.C., Morrison, D.A., and Maczuga, D.E., 1988, Anorthosites and related megacrystic units in the evolution of Archean Crust: Journal of Petrology, v. 29, p. 1283-1323, http://dx.doi.org/10.1093/petrology/29.6.1283.

Pilot, J., Werner, C-D., Haubrich, F., and Baumann, N., 1998, Palaeozoic and Proterozoic zircons from the Mid-Atlantic Ridge: Nature, v. 393, p. 676-679, http://dx.doi.org/10.1038/31452.

Polat, A., and Kerrich, R., 2001, Magnesian andesites, Nb-enriched basalt-andesites, and adakites from late-Archean $2.7 \mathrm{Ga}$ Wawa greenstone belts, Superior Province, Canada: implications for late Archean subduction zone petrogenetic processes: Contributions to Mineralogy and Petrology, v. 141, p. 36-52, http://dx.doi.org/10.1007/s004100000223.

Polat, A., and Kerrich, R., 2002, Nd-isotope systematics of $\sim 2.7$ Ga adakites, magnesian andesites, and arc basalts, Superior Province: Evidence for shallow crustal recycling at Archean subduction zones: Earth and Planetary Science Letters, v. 202, p. 345-360, http://dx.doi.org/10.1016/S0012-821X(02)00806-3.

Polat, A., Kerrich, R., and Wyman, D.A., 1998, The late Archean Schreiber-Hemlo and White River-Dayohessarah greenstone belts, Superior Province: collages of oceanic plateaus, oceanic arcs, and subduction-accretion complexes: Tectonophysics, v. 289, p. 295-326, http://dx.doi.org/10.1016/S0040-1951(98)00002 $\mathrm{X}$.

Poulsen, K.H., Robert, F., and Dubé, B., 2000, Geological classification of Canadian gold deposits: Geological Survey of Canada, Bulletin 540, 106 p., http://dx.doi.org/10.4095/211094.

Powell, W.G., Carmichael, D.M., and Hodgson, C.J., 1995, Conditions and timing of metamorphism in the southern Abitibi greenstone belt, Quebec: Canadian Journal of Earth Sciences, v. 32, p. 787-805, http://dx.doi.org/10.1139/e95-067.

Prendergast, M.D., 2004, The Bulawayan Supergroup: a late Archaean passive margin-related large igneous province in the Zimbabwe craton: Journal of the Geological Society, v. 161, p. 431-445, http://dx.doi.org/10.1144/0016-764902092

Prendergast, M.D., and Wingate, M.T.D., 2013, Zircon geochronology of late Archean komatiitic sills and their felsic country rocks, south-central Zimbabwe: A revised age for the Reliance komatiitic event and its implications: Precambrian Research, v. 229, p. 105-124, http://dx.doi.org/10.1016/j.precamres.2012.02.004

Pyke, D.R., Naldrett, A.J., and Eckstrand, O.R., 1973, Archean ultramafic flows in Munro Township, Ontario: Geological Society of America Bulletin, v. 84, p. 955-978, http://dx.doi.org/10.1130/0016-7606(1973)84<955:AUFIMT> 2.0.CO;2.

Rajamani, V., Shivkumar, K., Hanson, G.N., and Shirey, S.B., 1985, Geochemistry and petrogenesis of amphibolites, Kolar Schist Belt, south India: evidence for komatiitic magma derived by low percentages of melting of the mantle: Journal of Petrology, v. 26, p. 92-123, http://dx.doi.org/10.1093/petrology/26.1.92.

Reubi, O., and Blundy, J., 2009, A dearth of intermediate melts at subduction zone volcanoes and the petrogenesis of arc andesites: Nature, v. 461, p. 1269-1273, http://dx.doi.org/10.1038/nature08510.

Richards, J.P., and Kerrich, R., 2007, Special Paper: Adakite-like rocks: their diverse origins and questionable role in metallogenesis: Economic Geology, v. 102, p 537-576, http://dx.doi.org/10.2113/gsecongeo.102.4.537.

Robert, F., and Poulsen, K.H., 1997, World-class Archaean gold deposits in Canada: An overview: Australian Journal of Earth Sciences, v. 44, p. 329-351, http://dx.doi.org/10.1080/08120099708728316.

Robert, F., Poulsen, K.H., and Dubé, B., 1997, Gold Deposits and their Geological Classification, in Gubins, A.G., ed., Geophysics and Geochemistry at the Millenium: Prospectors and Developers Association of Canada, Toronto, $\mathrm{p}$ 209-220.

Robin, C.M.I., and Bailey, R.C., 2009, Simultaneous generation of Archean crust and subcratonic roots by vertical tectonics: Geology, v. 37, p. 523-526, http://dx.doi.org/10.1130/G25519A.1

Robinson, P.T., Malpas, J., Dilek, Y., and Zhou, M.-F., 2009, The significance of sheeted dike complexes in ophiolites: GSA Today, v. 18, p. 4-10, http://dx.doi.org/10.1130/GSATG22A.1.

Rogers, N., McNicoll, V., van Staal, C.R., and Tomlinson, K.Y., 2000, Lithogeochemical studies in the Uchi-Confederation greenstone belt, northwestern Ontario: implications for Archean tectonics: Geological Survey of Canada, Current Research Part C, p. 1-11, http://dx.doi.org/10.4095/211161
Ross, P.-S., and Mercier-Langevin, P., 2014, Igneous Rock Associations 14. The volcanic setting of VMS and SMS deposits: A review: Geoscience Canada, v. 41, p. 365-377, http://dx.doi.org/10.12789/geocanj.2014.41.045.

Ross, P.-S., Goutier, J., McNicoll, V.J., and Dubé, B., 2008, Volcanology and geochemistry of the Monsabrais area, Blake River Group, Abitibi greenstone belt Quebec: implications for volcanogenic massive sulphide exploration: Geological Survey of Canada, Current Research, p. 1-18, http://dx.doi.org/ $10.4095 / 224804$

Ross, P.-S., McNicoll, V.J., Debreil, J.-A., and Carr, P., 2014, Precise U-Pb geochronology of the Matagami mining camp, Abitibi greenstone belt, Quebec: stratigraphic constraints and implications for volcanogenic massive sulfide exploration: Economic Geology v. 109, p. 89-101, http://dx.doi.org/10.2113/ econgeo.109.1.89.

Sajona, F.G., Maury, R.C., Bellon, H., Cotten, J., and Defant, M., 1996, High field strength element enrichment of Pliocene-Pleistocene Island Arc Basalts. Zomboanga Peninsula, western Mindanao (Philippines): Journal of Petrology, v. 37, p. 693-726, http://dx.doi.org/10.1093/petrology/37.3.693.

Sanborn-Barrie, M., and Skulski, T., 2006, Sedimentary and structural evidence for 2.7 Ga continental arc-oceanic-arc collision in the Savant-Sturgeon greenstone belt, western Superior Province, Canada: Canadian Journal of Earth Sciences, v. 43, p. 995-1030, http://dx.doi.org/10.1139/e06-060.

Sanborn-Barrie, M., Skulski, T., and Parker, J., 2001, Three hundred million years of tectonic history recorded by the Red Lake greenstone belt, Ontario: Geological Survey of Canada, Current Research 2001-C19, p. 1-14.

Sanschagrin, Y., 1982, La Transition entre les Faciès Massifs et Coussinés d'un Ensemble de Coulées Basaltiques, Canton d'Aiguebelle, Québec: Mémoire de Maitrise, Université de Québec à Chicoutimi, QC.

Sappin, A.-A., Houlé, M.G., Lesher, C.M., and McNicoll, V., 2013, Overview of the Mafic and Ultramafic Intrusions in the Eastern Uchi Domain of the Superior Province, Northern Ontario: Ontario Geological Survey, Open File Report 6290 , p. $51-51$ to $51-16$

Saunders, A.D., Norry, M.J., and Tarney, J., 1991, Fluid influence on the trace element compositions of subduction zone magmas: Philosophical Transactions of the Royal Society London, Series A, v. 335, p. 377-392, http://dx.doi.org/ $10.1098 /$ rsta.1991.0053

Sawyer, E.W., and Barnes, S.-J., 1994, Thrusting, magmatic intraplating, and metamorphic core complex development in the Archaean Belleterre-Angliers greenstone belt, Superior Province, Quebec, Canada: Precambrian Research, v. 68, p. 183-200, http://dx.doi.org/10.1016/0301-9268(94)90029-9.

Scarrow, J.H., Molina, J.F., Bea, F., and Montero, P., 2009, Within-plate calc-alkaline rocks: Insights from alkaline mafic magma-peraluminous crustal melt hybrid appinites of the Central Iberian Variscan continental collision: Lithos, v. 110, p. 50-64, http://dx.doi.org/10.1016/j.lithos.2008.12.007.

Schmitz, M.D., Bowring, S.A., de Wit, M.J., and Gartz, V., 2004, Subduction and terrane collision stabilize the western Kaapvaal craton tectosphere 2.9 billion years ago: Earth and Planetary Science Letters, v. 222, p. 363-376, http://dx.doi.org/ 10.1016/j.epsl.2004.03.036.

Schwerdtner, W.M., 1984, Foliation patterns in large gneiss bodies of the Archaean Wabigoon Subprovince, southern Canadian Shield, in Kröner, A., and Zwart, H.J., eds., Precambrian Crustal Evolution: Journal of Geodynamics, v. 1, p. 313-337.

Scoates, J.S., and Scoates, R.F.J., 2013, Age of the Bird River Sill, southeastern Manitoba, Canada, with implications for the secular variation of layered intrusionhosted stratiform chromite mineralization: Economic Geology, v. 108, p. 895-907, http://dx.doi.org/10.2113/econgeo.108.4.895.

Scott, C.R., Mueller, W.U., and Pilote, P., 2002, Physical volcanology, stratigraphy and lithogeochemistry of an Archean volcanic arc: evolution from plume-related volcanism to arc rifting of SE Abitibi Greenstone Belt, Val d'Or, Canada: Precambrian Research, v. 115, p. 223-260, http://dx.doi.org/10.1016/S03019268(02)00011-6.

Sensarma, S., and Palme, H., 2013, Silicate liquid immiscibility in the $\sim 2.5 \mathrm{Ga}$ Fe-rich andesite at the top of the Dongargarh large igneous province (India): Lithos, v. 170-171, p. 239-251, http://dx.doi.org/10.1016/j.lithos.2013.03.004.

Shchipansky, A.A., Samsonov, A.V., Bibikova, E.V., Babarina, I.I., Konilov, A.N., Krylov, K.A., Slabunov, A.I., and Bogina, M.M., 2004, 2.8 Ga boninite-hosting partial suprasubduction zone ophiolite sequences from the North Karelian greenstone belt, NE Baltic Shield, Russia: Developments in Precambrian Geology, v. 13, p. 425-486.

Shegelski, R.J., 1980, Archean cratonization, emergence and red bed development, Lake Shebandowan area, Canada: Precambrian Research, v. 12, p. 331-347, http://dx.doi.org/10.1016/0301-9268(80)90034-0.

Shibuya, T., Tahata, M., Kitajima, K., Ueno, Y., Komiya, T., Yamamoto, S., Igisu, M., Terabayashi, M., Sawaki, Y., Takai, K., Yoshida, N., and Maruyama, S., 2012, Depth variation of carbon and oxygen isotopes of calcites in Archean altered upperoceanic crust: implications for the $\mathrm{CO}_{2}$ flux from ocean to oceanic crust in the Archean: Earth and Planetary Science Letters, v. 321-322, p. 64-73, 
http://dx.doi.org/10.1016/j.epsl.2011.12.034.

Shirey, S.B., and Hanson, G.N., 1986, Mantle heterogeneity and crustal recycling in Archean granite-greenstone belts: Evidence from $\mathrm{Nd}$ isotopes and trace elements in the Rainy Lake area, Superior Province, Ontario, Canada: Geochimica et Cosmochimica Acta, v. 50, p. 2631-2651, http://dx.doi.org/10.1016/00167037(86)90215-2.

Silver, P.G., and Behn, M.D., 2008, Intermittent plate tectonics?: Science, v. 319, p. 85-88, http://dx.doi.org/10.1126/science.1148397.

Silver, P.G., and Chan, W.W., 1991, Shear wave splitting and subcontinental mantle deformation: Journal of Geophysical Research, v. 96, p. 16429-16454, http://dx.doi.org/10.1029/91JB00899.

Simard, M., Gaboury, D., Daigneault, R., and Mercier-Langevin, P., 2013, Multistage gold mineralization at the Lapa Mine, Abitibi Subprovince: insights into auriferous hydrothermal and metasomatic processes in the Cadillac-Larder Lake fault zone: Mineralium Deposita, v. 48, p. 883-905, http://dx.doi.org/ 10.1007/s00126-013-0466-3

Slabunov, A.I., Lobach-Zhuchenko, S.B., Bibikova, E.V., Balagansky, V.V., SorjonenWard, P., Volodichev, O.I., Shchipansky, A.A., Svetov, S.A., Chekulaev, V.P., Arestova, N.A., and Stepanov, V.S., 2006, The Archean of the Baltic Shield: geology, geochronology, and geodynamic settings: Geotectonics, v. 40, p. 409-433, http://dx.doi.org/10.1134/S001685210606001X.

Sleep, N.H., and Windley, B.F., 1982, Archean plate tectonics: Constraints and inferences: The Journal of Geology, v. 90, p. 363-379, http://dx.doi.org/ $10.1086 / 628691$.

Smith, T.E., and Longstaffe, F.., 1974, Archean rocks of shoshonitic affinities at Bijou Point, northwestern Ontario: Canadian Journal of Earth Sciences, v. 11, p. 1407-1413, http://dx.doi.org/10.1139/e74-135.

Smithies, R.H., 2002, Archaean boninite-like rocks in an intracratonic setting: Earth and Planetary Science Letters, v. 197, p. 19-34, http://dx.doi.org/10.1016/ S0012-821X(02)00464-8.

Smithies, R.H., and Champion, D.C., 1999, Late Archaean felsic alkaline igneous rocks in the Eastern Goldfields, Yilgarn Craton, Western Australia; a result of lower crustal delamination?: Journal of the Geological Society, v. 156, p. 561-576, http://dx.doi.org/10.1144/gsigs.156.3.0561

Smithies, R.H., and Champion, D.C., 2000, The Archaean High-Mg diorite suite: Links to Tonalite-Trondhjemite-Granodiorite magmatism and implications for early Archaean crustal growth: Journal of Petrology, v. 41, p. 1653-1671, http://dx.doi.org/10.1093/petrology/41.12.1653.

Smithies, R.H., Champion, D.C., Van Kranendonk, M.J., Howard, H.M., and Hickman, A.H., 2005, Modern-style subduction processes in the Mesoarchaean: Geochemical evidence from the $3.12 \mathrm{Ga}$ Whundo intra-oceanic arc: Earth and Planetary Science Letters, v. 231, p. 221-237, http://dx.doi.org/10.1016/ j.epsl.2004.12.026.

Smithies, R.H., Champion, D.C., and Van Kranendonk, M.J., 2007, The oldest well preserved felsic volcanic rocks on Earth: geochemical clues to the early evolution of the Pilbara Supergroup and implications for the growth of a Paleoarchean protocontinent: Developments in Precambrian Geology, v. 15, p 339-367.

Snyder, D.L., Bleeker, W., Reed, L.E., Ayer, J.A., Houlé, M.G., and Bateman, R., 2008, Tectonic and metallogenic implications of regional seismic profiles in the Timmins Mining Camp: Economic Geology, v. 103, p. 1135-1150, http://dx.doi.org/10.2113/gsecongeo.103.6.1135.

Sproule, R.A., Lesher, C.M., Ayer, J.A., Thurston, P.C., and Herzberg, C.T., 2002, Spatial and temporal variations in the geochemistry of komatiites and komatiitic basalts in the Abitibi Greenstone belt: Precambrian Research, v. 115, p. 153-186, http://dx.doi.org/10.1016/S0301-9268(02)00009-8.

Sproule, R.A., Lesher, C.M., Houlé, M.G., Keays, R.R., Ayer, J.A., and Thurston, P.C., 2005, Chalcophile element geochemistry and metallogenesis of komatiitic rocks in the Abitibi Greenstone Belt, Canada: Economic Geology, v. 100, p. 1169-1190, http://dx.doi.org/10.2113/gsecongeo.100.6.1169.

Stern, R.J., 2005, Evidence from ophiolites, blueschists, and ultrahigh-pressure metamorphic terranes that the modern episode of subduction tectonics began in Neoproterozoic time: Geology, v. 33, p. 557-560, http://dx.doi.org/10.1130/ G21365.1.

Stern, R.J., 2008, Modern-style plate tectonics began in Neoproterozoic time: An alternative interpretation of Earth's tectonic history, in Condie, K.C., and Pease, C., eds., When Did Plate Tectonics Begin on Planet Earth?: Geological Society of America, Special Papers, v. 440, p. 265-280, http://dx.doi.org/10.1130/ 2008.2440(13)

Stone, D., 1998, Precambrian Geology of the Berens River area, northwestern Ontario: Ontario Geological Survey, Open File Report 5963, 116 p.

Stone, D., 2005, Geology of the northern Superior area, Ontario: Ontario Geological Survey, Open File Report 6140, 94 p.

Stone, D., 2010, Precambrian Geology of the Central Wabigoon Subprovince area, northwestern Ontario: Ontario Geological Survey, Open File Report 5422, 130 p.
Stone, D., Kamineni, D.C., and Jackson, M.C., 1992, Precambrian Geology of the Atikokan Area, Northwestern Ontario: Geological Survey of Canada, Bulletin 405, $106 \mathrm{p}$.

Stone, W.E., 1990, Archean volcanism and sedimentation in the Bousquet gold district, Abitibi greenstone belt, Quebec: Implications for stratigraphy and gold concentration: Geological Society of America Bulletin, v. 102, p. 147-158, http://dx.doi.org/10.1130/0016-7606(1990)102<0147:AVASIT>2.3.CO;2.

Stone, W.E., Crocket, J.H., Dickin, A.P., and Fleet, M.E., 1995, Origin of Archean ferropicrites: geochemical constraints from the Boston Creek Flow, Abitibi greenstone belt, Ontario, Canada: Chemical Geology, v. 121, p. 51-71, http://dx.doi.org/10.1016/0009-2541(94)00126-S.

Storey, M., Mahoney, J.J., Kroenke, L.W., and Saunders, A.D., 1991, Are oceanic plateaus sites of komatiite formation?: Geology, v. 19, p. 376-379, http://dx.doi.org/10.1130/0091-7613(1991)019<0376:AOPSOK>2.3.CO;2.

Stott, G., 1986, A structural analysis of the central part of the Archean Shebandowan Greenstone belt and a crescent-shaped granitoid pluton, northwestern Ontario: Unpublished $\mathrm{PhD}$ thesis, University of Toronto, Toronto, ON, $285 \mathrm{p}$.

Stott, G.M., and Corfu, F., 1991, Uchi subprovince, in Thurston, P.C., Williams, H.R., Sutcliffe, R.H., and Stott, G.M., eds., Geology of Ontario: Ontario Geological Survey, p. 145-238.

Sun, S.-s. and McDonough, W.F., 1989, Chemical and isotopic systematics of oceanic basalts; implications for mantle composition and processes, in Saunders, A.D., and Norry, M.J., eds., Magmatism in the Ocean Basins: Geological Society, London, Special Publications, v. 42, p. 313-345, http://dx.doi.org/10.1144/ GSL.SP.1989.042.01.19.

Sun, S.-S., and Nesbitt, R.W., 1978, Petrogenesis of Archaean ultrabasic and basic volcanics: Evidence from rare earth elements: Contributions to Mineralogy and Petrology, v. 65, p. 301-325, http://dx.doi.org/10.1007/BF00375516.

Sun, S.-S., Nesbitt, R.W., and McCulloch, M.T., 1989, Geochemistry and petrogenesis of Archaean and early Proterozoic siliceous high-magnesian basalts, in Crawford, A.J., ed., Boninites: University of Tasmania, Hobart, Tasmania, p. 148-173.

Sutcliffe, H.R., Sweeny, J.M., and Edgar, A.D., 1989, The Lac des Iles Complex, Ontario: Petrology and platinum-group-elements mineralization in an Archean mafic intrusion: Canadian Journal of Earth Sciences, v. 26, p. 1408-1427, http://dx.doi.org/10.1139/e89-120.

Sutcliffe, H.R., Barrie, C.T., Burrows, D.R., and Beakhouse, G.P., 1993, Plutonism in the southern Abitibi Subprovince: A tectonic and petrogenetic framework: Economic Geology, v. 88, p. 1359-1375, http://dx.doi.org/10.2113/gsecongeo.88.6.1359

Svetov, S.A., 2001, Archean high-MgO volcanism in East Fennoscandia (Abstract), in Cassidy, K.F., Dunphy, J.M., and Van Kranendonk, M.J., eds, 4th International Archean Symposium Extended Abstracts: Geoscience Australia, p. 199-200.

Svetov, S.A., Huhma, H., Svetova, A.I., and Nazarova, T.N., 2004, The oldest adakites in the Fennoskandian shield: Doklady Akademii Nauk 397, p. 810-814.

Swager, C., Witt, W.K., Griffin, T.J., Ahmat, A.L., Hunter, W.M., McGoldrick, P.J., and Wyche, S., 1990, A Regional Overview of the Late Archaean GraniteGreenstones of the Kalgoorlie Terrane, in Ho, S.E., Glover, J.E., Myers, J.S., and Muhling, J.R., eds.,Third International Archaean Symposium, Perth 1990 Excursion Guidebook, University of Western Australia, Perth, AU, p. 205-303.

Sylvester, P.J., Harper, G.D., Byerly, G.R., and Thurston, P.C., 1997, Volcanic Aspects, in de Wit, M.J., and Ashwal, L.D., eds., Greenstone Belts: Clarendon Press, Oxford, UK, p. 55-90.

Szilas, K., Hoffmann, J.E., Scherstén, A., Kokfelt, T.F., and Münker, C., 2013, Archaean andesite petrogenesis: Insights from the Grædefjord Supracrustal Belt, southern West Greenland: Precambrian Research, v. 236, p. 1-15, http://dx.doi.org/10.1016/j.precamres.2013.07.013.

Taner, M.F., Gault, R.A., and Scott, E.T., 2000, Vanadium mineralization and its industry in Canada: The Gangue 65, p. 1-9.

Tapster, S., Roberts, N.M.W., Petterson, M.G., Saunders, A.D., and Naden, J., 2014, From continent to intra-oceanic arc: Zircon xenocrysts record the crustal evolution of the Solomon island arc: Geology, v. 42, p. 1087-1090, http://dx.doi.org/10.1130/G36033.1.

Tatsumi, Y., 2005, The subduction factory: How it operates in the evolving Earth: GSA Today, v. 15, p. 4-10, http://dx.doi.org/10.1130/1052-5173(2005)015 [4:TSFHIO]2.0.CO;2.

Taylor, S.R., and Hallberg, J.A., 1977, Rare-earth elements in the Marda calc-alkaline suite: An Archaean geochemical analogue of Andean type volcanism: Geochimica et Cosmochimica Acta, v. 41, p. 1125-1129, http://dx.doi.org/ 10.1016/0016-7037(77)90107-7.

Taylor, S.R., and McLennan, S.M., 1985, The continental crust: its composition and evolution: Blackwell Scientific, Oxford, 312 p.

Taylor, W.R., Rock, N.M.S., and Groves, D.I., 1990, The gold-shoshonitic lamprophyre association: new geochemical data and the tectonic context of Archaean lamprophyres from the Yilgarn Block, Western Australia (Abstract): Geological Society of Australia, Abstracts, 28, p. 2. 
Terabayashi, M., Masada, Y., and Ozawa, H., 2003, Archean ocean-floor metamorphism in the North Pole area, Pilbara Craton, Western Australia: Precambrian Research, v. 127, p. 167-180, http://dx.doi.org/10.1016/S0301-9268(03) 00186-4.

Thomson, J.E., 1946, The Keewatin-Timiskaming unconformity in the Kirkland lake District: Royal Society of Canada, Transactions, IV, p. 113-124.

Thorkelson, D.J., 1996, Subduction of diverging plates and the principles of slab window formation: Tectonophysics, v. 255, p. 47-63, http://dx.doi.org/ 10.1016/0040-1951(95)00106-9.

Thurston, P., 2012, Archean sedimentary rocks: record of a different world OR Where's the mud (Abstract): Geological Association of Canada-Mineralogical Association of Canada, Annual Meeting St. John's, NL, p. 140.

Thurston, P., Ayer, J.A., Goutier, J., and Hamilton, M.A., 2008, Depositional Gaps in Abitibi Greenstone Belt Stratigraphy: A key to exploration for syngenetic mineralization: Economic Geology, v. 103, p. 1097-1134, http://dx.doi.org/ 10.2113/gsecongeo.103.6.1097.

Thurston, P., Kamber, B.S., and Whitehouse, M., 2012, Archean cherts in banded iron formation: Insight into Neoarchean ocean chemistry and depositional processes: Precambrian Research, v. 214-215, p. 227-257, http://dx.doi.org/ 10.1016/j.precamres.2012.04.004.

Thurston, P.C., 1980, Subaerial volcanism in the Archean Uchi-Confederation Volcanic Belt: Precambrian Research, v. 12, p. 79-98, http://dx.doi.org/ 10.1016/0301-9268(80)90024-8.

Thurston, P.C., 1981, The Volcanology and Trace Element Geochemistry of Cyclical Volcanism in the Archean Confederation lake Area, Northwestern Ontario: Unpublished $\mathrm{PhD}$ thesis, University of Western Ontario, London, ON, 553 p.

Thurston, P.C., 1991, Archean Geology of Ontario: Introduction, in Thurston, P.C., Williams, H.R. Sutcliffe, R.H., and Stott, G.M., eds., Geology of Ontario: Ontario Geological Survey, p. 73-80.

Thurston, P.C., 2002, Autochthonous development of Superior Province greenstone belts?: Precambrian Research, v. 115, p. 11-36, http://dx.doi.org/10.1016/ S0301-9268(02)00004-9.

Thurston, P.C., 2003, The balance between autochthonous and allochthonous development of Superior Province Greenstones (Abstract): GAC-MAC, Annual Meeting Vancouver, BC, Abstracts 28, p. 170.

Thurston, P.C., and Ayres, L.D., 2004, Archaean and Proterozoic greenstone belts: Setting and Evolution, in Eriksson, P.G., Altermann, W., Nelson, D.R., Mueller, W., and Catuneanu, O., eds., The Precambrian Earth: Tempos and Events: Elsevier, Amsterdam, p. 311-333.

Thurston, P.C., and Breaks, F.W., 1978, Metamorphic and tectonic evolution of the Uchi-English River Subprovince: Geological Survey of Canada, Paper 78-10, p. 49-62.

Thurston, P.C., and Carter, M.W., 1970, Operation Fort Hope: Ontario Division of Mines, Toronto, ON, $60 \mathrm{p}$.

Thurston, P.C., and Chivers, K.M., 1990, Secular variation in greenstone sequence development emphasizing Superior Province, Canada: Precambrian Research, v. 46, p. 21-58, http://dx.doi.org/10.1016/0301-9268(90)90065-X.

Thurston, P.C., and Fryer, B.J., 1983, The geochemistry of repetitive cyclical volcanism from basalt through rhyolite in the Uchi-Confederation greenstone belt, Canada: Contributions to Mineralogy and Petrology, v. 83, p. 204-226, http://dx.doi.org/10.1007/BF00371189.

Thurston, P.C., and Kozhevnikov, V.N., 2000, An Archean quartz arenite-andesite association in the eastern Baltic Shield, Russia: implications for assemblage types and shield history: Precambrian Research, v. 101, p. 313-340, http://dx.doi.org/10.1016/S0301-9268(99)00093-5.

Thurston, P.C., and Sutcliffe, R.H., 1986, The Archean crust as a density filter (Abstract): Geological Association of Canada-Mineralogical Association of Canada-Canadian Geophysical Union Abstracts, Joint Annual Meeting 11, p. 136.

Thurston, P.C., Ayres, L.D., Edwards, G.R., Gélinas, L., Ludden, J.N., and Verpaelst, P., 1985, Archean bimodal volcanism: Geological Association of Canada, Special Paper 28, p. 7-21.

Thurston, P.C., Osmani, I.A., and Stone, D., 1991, Northwestern Superior Province: review and terrane analysis, in Thurston, P.C., Williams, H.R., Sutcliffe, R.H., and Stott, G.M., eds., Geology of Ontario: Ontario Geological Survey, p. 81-142.

Tipper, H.W., Woodsworth, G.J., and Gabrielse, H., 1981, Tectonic assemblage map of the Canadian Cordillera: Geological Survey of Canada, Map 1505A, scale: $1: 2,000,000$

Tomlinson, K.Y., Hall, R.P., Hughes, D.J., and Thurston, P.C., 1996, Geochemistry and assemblage accretion of metavolcanic rocks in the Beardmore-Geraldton greenstone belt, Superior Province: Canadian Journal of Earth Sciences, v. 33, p. 1520-1533, http:dx.doi.org/10.1139/e96-115.

Tomlinson, K.Y., Davis, D.W., Stone, D., and Hart, T.R., 2003, U-Pb age and Nd isotopic evidence for Archean terrane development and crustal recycling in the south-central Wabigoon subprovince, Canada: Contributions to Mineralogy and
Petrology, v. 144, p. 684-702, http://dx.doi.org/10.1007/s00410-002-0423-0.

Tormanen, T., and Karinen, T., 2011, Chrome and PGE deposits associated with the $2.45 \mathrm{Ga}$ layered intrusions of northern Finland: Excursion Guide, 24 August 2011, Vuorimiesyhdistys, Outokumpu, Finland.

Ujike, O., Goodwin, A.M., and Shibata, T., 2007, Geochemistry and origin of Archean volcanic rocks from the Upper Keewatin assemblage (ca $2.7 \mathrm{Ga}$ ), Lake of the Woods Greenstone Belt, Western Wabigoon Subprovince, Superior Province, Canada: Island Arc, v. 16, p. 191-208, http://dx.doi.org/10.1111/ j.1440-1738.2007.00566.x

van der Velden, A.J., and Cook, F.A., 2005, Relict subduction zones in Canada: Journal of Geophysical Research, v. 110, B08403, http://dx.doi.org/10.1029/ 2004JB003333.

Van Kranendonk, M.J., 2000, Geology of the North Shaw 1:100,000 Sheet, Geological Survey of Western Australia, 86 p.

Van Kranendonk, M.J., 2012, A chronostratigraphic Division of the Precambrian: Possibilities and Challenges, in: Gradstein, F.M., Ogg, J.G., Schmitz, M.D., and Ogg, G.M., eds., The Geologic Time Scale 2012. Vol. 1, p. 299-392.

Van Kranendonk, M.J., Hickman, A.H., Smithies, R.H., and Nelson, D.R., 2002, Geology and tectonic evolution of the Archean North Pilbara Terrain, Pilbara Craton, Western Australia: Economic Geology, v. 97, p. 695-732.

Van Kranendonk, M.J., Collins, W.J., Hickman, A.H., and Pawley, M.J., 2004, Critical tests of vertical $v s$. horizontal tectonic models for the Archaean East Pilbara Granite-Greenstone Terrane, Pilbara Craton, Western Australia: Precambrian Research, v. 131, p. 173-211, http://dx.doi.org/10.1016/j.precamres.2003.12.015

Van Kranendonk, M.J., Smithies, R.H., Hickman, A.H., and Champion, D.C., 2007a, Paleoarchean development of a continental nucleus: the East Pilbara Terrane of the Pilbara Craton, Western Australia: Developments in Precambrian Geology, v. 15 , p. $307-337$.

Van Kranendonk, M.J., Smithies, R.H., Hickman, A.H., and Champion, D.C., 2007b, Review: secular tectonic evolution of Archean continental crust: interplay between horizontal and vertical processes in the formation of the Pilbara Craton, Australia: Terra Nova, v. 19, p. 1-38, http://dx.doi.org/10.1111/j.13653121.2006.00723.x.

Van Kranendonk, M.J., Ivanic, T.J., Wingate, M.T.D., Kirkland, C.L., and Wyche, S., 2013, Long-lived, autochthonous development of the Archean Murchison domain, and implications for Yilgarn craton tectonics: Precambrian Research, v. 229, p. 49-92, http://dx.doi.org/10.1016/j.precamres.2012.08.009.

Vervoort, J.D., White, W.M., and Thorpe, R.I., 1994, Nd and Pb isotope ratios of the Abitibi greenstone belt: new evidence for very early differentiation of the Earth: Earth and Planetary Science Letters, v. 128, p. 215-229, http://dx.doi.org/10.1016/0012-821X(94)90146-5.

Wang, Z., Wilde, S.A., Wang, K., and Yu, L., 2004, A MORB-arc basalt-adakite association in the $2.5 \mathrm{Ga}$ Wutai greenstone belt: late Archean magmatism and crustal growth in the North China Craton: Precambrian Research, v. 131, p 323-343, http://dx.doi.org/10.1016/j.precamres.2003.12.014

Whalen, J.B., Percival, J.A., McNicoll, V.J., and Longstaffe, F.J., 2004, Geochemical and isotopic $(\mathrm{Nd}-\mathrm{O})$ evidence bearing on the origin of late- to post-orogenic high-K granitoid rocks in the Western Superior Province: Implications for late Archean tectonomagmatic processes: Precambrian Research, v. 132, p. 303-326, http://dx.doi.org/10.1016/j.precamres.2003.11.007.

White, D., Musacchio, G., Helmstaedt, H., Harrap, R., Thomson, C., Sol, S., and Thurston, P.C., 2001, Remnants of Archean Subduction in the Western Superior Province: Results from combined LITHOPROBE Deep Seismic Studies (Abstract): Lithoprobe Superior Transect, Abstracts.

White, D.J., Musacchio, G., Helmstaedt, H.H., Harrap, R.M., Thurston, P.C., van der Velden, A., and Hall, K., 2003, Images of a lower-crustal oceanic slab: Direct evidence for tectonic accretion in the Archean Western Superior Province: Geology, v. 31, p. 997-1000, http://dx.doi.org/10.1130/G20014.1

Whittaker, P.J., 1986, Chromite deposits in Ontario: Ontario Geological Survey, Resources, Toronto, ON.

Wilks, M.E., and Nisbet, E.G., 1988, Stratigraphy of the Steep Rock Group, northwest Ontario: a major Archaean unconformity and Archaean stromatolites: Canadian Journal of Earth Science, v. 25, p. 370-391, http://dx.doi.org/ $10.1139 / \mathrm{e} 88-040$.

Willbold, M., Hegner, E., Stracke, A., and Rocholl, A., 2009, Continental geochemical signatures in dacites from Iceland and implications for models of early Archaean crust formation: Earth and Planetary Science Letters, v. 279, p. 44-52, http://dx.doi.org/10.1016/j.epsl.2008.12.029

Williams, H.R., 1991, Quetico Subprovince: Ontario Geological Survey, Special Volume 4, p. 383-403.

Williams, H.R., Stott, G.M., and Thurston, P.C., 1992, Tectonic evolution of Ontario: summary and synthesis. Part 1: Revolution in the Superior Province, in Thurston, P.C., Williams, H.R., Sutcliffe, R.H., and Stott, G.M., eds., Geology of Ontario: Geological Survey of Ontario, p. 1255-1294.

Wilson, A.H., 2002, Early Archaean highly-depleted ultramafic boninitic lavas in the 
southern Kaapvaal Craton, South Africa (Abstract): Geochimica et Cosmochimica Acta, Abstracts of the $12^{\text {th }}$ annual Goldschmidt Conference, v. 66, p. 839

Windley, B.F., and Garde, A.A., 2009, Arc-generated blocks with crustal sections in the North Atlantic Craton of West Greenland; crustal growth in the Archean with modern analogues: Earth-Science Reviews, v. 93, p. 1-30, http://dx.doi.org/10.1016/j.earscirev.2008.12.001.

Winter, J.D., 2001, An Introduction to igneous and Metamorphic Petrology: Prentice Hall, Upper Saddle River, NJ, 697 p.

Wray, N., 2014, Evidence for a younger Porcupine age komatiitic volcanism in the Abitibi greenstone belt, Ontario: Unpublished BSc thesis, Laurentian University, Sudbury, ON, 45 p.

Wyman, D., and Hollings, P., 1998, Long-lived mantle-plume influence on an Archean protocontinent; geochemical evidence from the $3 \mathrm{Ga}$ Lumby Lake greenstone belt, Ontario, Canada: Geology, v. 26, p. 719-722, http://dx.doi.org/10.1130/0091-7613(1998)026<0719:LLMPIO>2.3.CO;2.

Wyman, D., and Kerrich, R., 1989, Archean shoshonitic lamprophyres associated with Superior Province gold deposits, distribution, tectonic setting, noble metal abundances, and significance for gold mineralization: Economic Geology Monographs, v. 6, p. 651-667.

Wyman, D., and Kerrich, R., 2009, Plume and arc magmatism in the Abitibi Subprovince: implications for the origin of Archean continental lithospheric mantle: Precambrian Research, v. 168, p. 4-22, http://dx.doi.org/10.1016/j.precamres.2008.07.008.

Wyman, D.A., and Kerrich, R., 2012, Geochemical and isotopic characteristics of Youanmi terrane volcanism: The role of mantle plumes and subduction tectonics in the western Yilgarn Craton: Australian Journal of Earth Sciences, v. 59, p. 671-694, http://dx.doi.org/10.1080/08120099.2012.702684.

Wyman, D.A., Ayer, J.A., and Devaney, J.R., 2000, Niobium-enriched basalts from the Wabigoon Subprovince, Canada: evidence for adakitic metasomatism above an Archean subduction zone: Earth and Planetary Science Letters, v. 179, p. 21-30, http://dx.doi.org/10.1016/S0012-821X(00)00106-0.

Wyman, D.A., Kerrich, R., and Polat, A., 2002, Assembly of Archean cratonic mantle lithosphere and crust; plume-arc interaction in the Abitibi-Wawa subductionaccretion complex: Precambrian Research, v. 115, p. 37-62, http://dx.doi.org/ 10.1016/S0301-9268(02)00005-0.

Wyman, D.A., Hollings, P., and Biczok, J., 2011, Crustal evolution in a cratonic nucleus: Granitoids and felsic volcanic rocks of the North Caribou Terrane, Superior Province Canada: Lithos, v. 123, p. 37-49, http://dx.doi.org/10.1016/ j.lithos.2010.07.025.

Xie, Q., Kerrich, R., and Fan, J., 1993, HFSE/REE fractionations recorded in three komatiite-basalt sequences, Archean Abitibi greenstone belt: Implications for multiple plume sources and depths: Geochimica et Cosmochimica Acta, v. 57, p. 4111-4118, http://dx.doi.org/10.1016/0016-7037(93)90357-3.

Yogodzinski, G.M., Kay, R.W., Volynets, O.N., Koloskov, A.V., and Kay, S.M., 1995, Magnesian andesite in the western Aleutian Komandorsky region: Implications for slab melting and processes in the mantle wedge: Geological Society of America Bulletin, v. 107, p. 505-519, http://dx.doi.org/10.1130/00167606(1995)107<0505:MAITWA>2.3.CO;2.

Zegers, T.E., White, S.H., de Keijzer, M., and Dirks, P., 1996, Extensional structures during deposition of the $3460 \mathrm{Ma}$ Warrawoona Group in the eastern Pilbara Craton, Western Australia: Precambrian Research, v. 80, p. 89-105, http://dx.doi.org/10.1016/S0301-9268(96)00007-1.

Zhai, M., Zhao, G., and Zhang, Q., 2002, Is the Dongwanzi complex an Archean ophiolite?: Science, v. 295, p. 923a, http://dx.doi.org/10.1126/science.295.5557.923a.

\section{Received August 2014}

Accepted as revised May 2015 